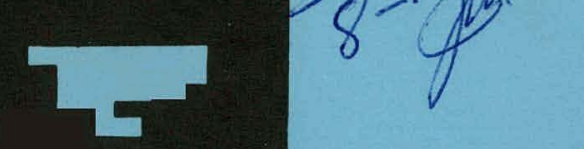

DOE/MC/12420-T1

\title{
A CLOSED LOOP TEST FACILITY FOR HOT DIRTY GAS VALVES
}

Technical Report

\section{MASTER}

February 6, 1980

Work Performed Under Contract No. AC21-79MC12420

Wyle Laboratories

Scientific Services \& Systems Group

Norco, California

\section{U. S. DEPARTMENT OF ENERGY}




\section{DISCLAIMER}

This report was prepared as an account of work sponsored by an agency of the United States Government. Neither the United States Government nor any agency Thereof, nor any of their employees, makes any warranty, express or implied, or assumes any legal liability or responsibility for the accuracy, completeness, or usefulness of any information, apparatus, product, or process disclosed, or represents that its use would not infringe privately owned rights. Reference herein to any specific commercial product, process, or service by trade name, trademark, manufacturer, or otherwise does not necessarily constitute or imply its endorsement, recommendation, or favoring by the United States Government or any agency thereof. The views and opinions of authors expressed herein do not necessarily state or reflect those of the United States Government or any agency thereof. 


\section{DISCLAIMER}

Portions of this document may be illegible in electronic image products. Images are produced from the best available original document. 


\section{DISCLAIMER}

"This book was prepared as an account of work sponsored by an agency of the United States Fovernment. Neither the United States Fovernment nor any agency therenf, nor any of theiı enpluyees, makes any wantanty, expıess ui inplied, ui assumes any legal liability oi responsibility for the accuracy, completeness, or usefulness of any information, apparatus, product, or process disclosed, or represents that its use would not infringe privately owned rights. Reference herein to any specific commercial product, process, or service by trade name, trademark, manufacturer, or otherwise, does not necessarily constitute or imply its endorsement, recommendation, or favoring by the United States Government or any agency thereof. The views and opinions of authors expressed herein do not necessarily state or reflect those of the United States Government or any agency thereof."

This report has been reproduced directly from the best available copy.

Available from the National Technical Information Service, U. S. Department of Commerce, Springfield, Virginia 22161.

Price: Paper Copy $\$ 9.00$

Microfiche $\$ 3.50$ 


\section{WME LABORATORIES}

SCIENTIFIC SERVICES \& SYSTEMS GROUP WESTERN OPERATIONS, NORCO FACILITY
DOE/MC/12420-T1

Distribution Categories UC-90 and UC-90c

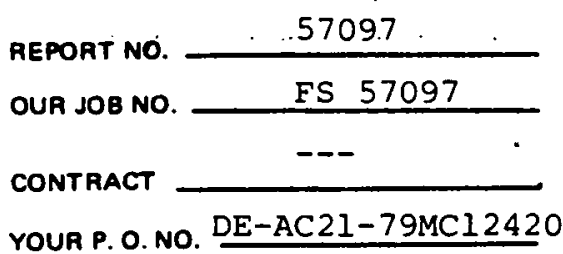

U. S. Department of Energy

Morgantown Energy : Technology Center :

880 Collins Ferry Road

Morgantown; West Virginia 26505

DATE 6 February 1980

\title{
TECHNICAL REPORT
}

REVISION A

21 May 1980

\author{
A CLOSED LOOP TEST FACILITY \\ FOR \\ HOT DIRTY GAS VALVES
}

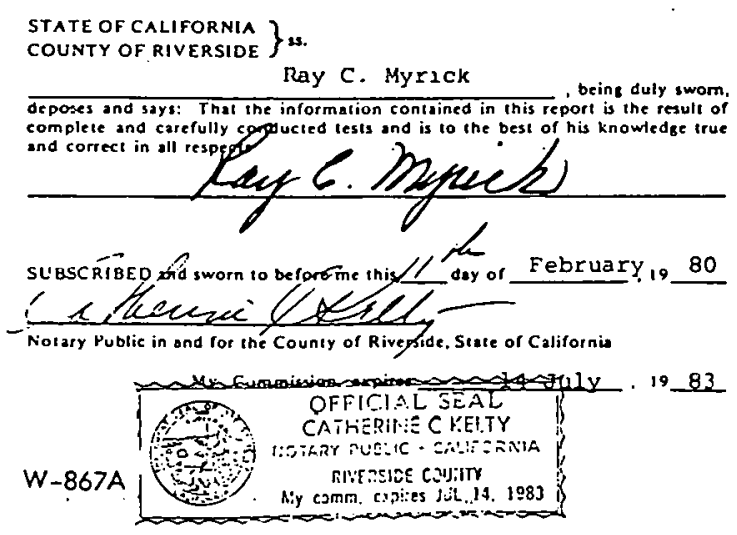

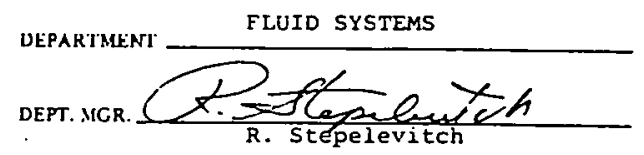

TEST ENGINEER

TEST HITNESS

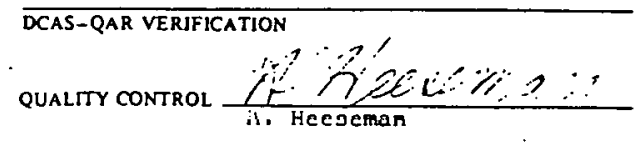


MME LABORATORiES

REPORT NO

57097

SCIENTIFIC SERVICES \& SYSTEMS GROUP

PAge No

i $i$

REVISION A

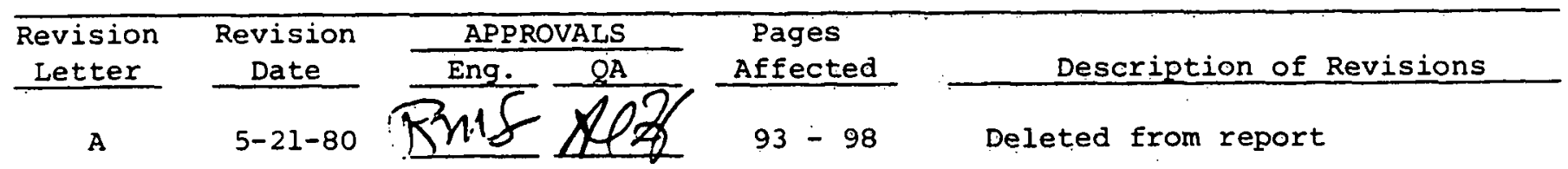

$\because$ 
A design study of a closed loop test facility for eightinch hot dirty gas valves is presented. The objective of the facility is to qualify valves for use in coal gasifiers, combined cycle plants, and pressurized fluid bed combustors. Outline sketches and estimated costs are presented for the selected design. 
SECTION

1

2

3

4

5

6

7
TITLE
ABSTRACT
SUMMARY
INTRODUCTION
TRADE-OFF STUDIES
RM-250 SYSTEM DESCRIPTION
ORGANIZATION AND FACILITIES
DEVELOPMENT AND CONSTRUCTION PLAN
ESTIMATED COST 
Hot dirty gas valves are used in coal gasifiers, combined cycle plánts; and pressurized fluid bed combustors to throttle dirty fuel gas at pressures of $250 \mathrm{psi}$ and temperatures of 1650F. The hot dirty gas valves in use today last only a short duration because of the rugged duty, however, valves capable of lifetimes over 8000 hours will be required before coal conversion plants can be successfully operated. Better valves can only be developed in a timely manner if there is a facility to test them in a representative environment for extended periods of time.

A trade-off study was conducted to examine closed loop test facilities for eight-inch valves; one facility operated at 250 psig and the second operated at 50 psig. The 50 psig facility was studied because at the outset it was felt that the 250 psig facility would be prohibitively expensive. Systems were studied with heat exchangers of a conventional design and with heat exchangers using a new technique of recirculating refractory media. It was hoped that the new technique would reduce costs sufficiently to make a 250 psi facility be economically attractive. Results of the trade-off study indicated that a 250 psi facility using the recirculating media heat exchanger could be constructed and operated for approximately the cost of a 50 psi facility using a conventional design heat exchanger. An additional bonus was that the 250 psi recirculating media facility required only 20 per cent of the fuel of the 50 psi conventional design facility.

The recirculating media heat exchanger (media are one-quarter inch alumina spheres) captures heat from the hot fuel gas downstream of the test valve by allowing the gas to heat the media as it passes through it. The gas is also cleaned of particulate in passing through the media. The cooled and cleaned gas is recompressed by a conventional gas compressor; after recompression it passes back through the heated media and recovers most of the heat it lost earlier. The refractory media operates at maximum system temperatures (1750F) without corrosion; conditions no metal heat exchanger will withstand. 
The closed loop test facility for eight-inch valves would fit on a $50^{\prime} x$ $50^{\prime}$ concrete pad and would project 85 feet above the pad. The valve test cell would be at ground level. The facility would be located at the Norco test site of Wyle Laboratories, one of the major independent testing laboratories in the country. Norco is located in Southern California near Los Angeles.

The cost of the construction of the facility would be $\$ 10,700,000$, and its normal operating cost for 8000 hours of cestlny wulld be $\$ 2,295,000$.

- A one-time cost of $\$ 766,000$ is charged at the end of the first year's operation to provide a complete spare set of hot gas piping and to. . install it at the facility. 
The Morgantown Energy Technology Center of the Department of Energy is currently considering the construction of a closed loop facility to test hot, dirty gas valves up to eight inches diameter in a representative environment of a coal gasifier, a combined cycle plant, or a pressurized fluid bed combustor. The hot gas valves in duty today frequently fail in a short duration because of the rugged duty, however, valves capable of reliable operation for over 8000 hours are required before coal conversion plants can be successfully operated.

Better valves can only be developed in a timely manner if there is some facility to test them in a representative environment for extended periods of time. A survey of the valve industry by TRW Energy systems indicates that valve manufacturers feel that eight-inch valve testing will be adequate to provide design information for full scale 28-inch valves. Several industry sources have volunteered to provide new valves free of charge if the Department of Energy would provide the testing.

Specifications METC/CR 79-6, -8, $-10,-12$, and -14 have been provided by METC to guide the design of the valve test facility. These specifications specified a 50 psig facility, but asked that components be designed to a 250 psig pressure level. At the 50 psig level a cogas hot gas valve could be tested, but the facility would be unable to test valves for the combined cycle gasifiers and for pressurized fluid bed combustors, severely limiting its usefulness. A facility in the 250 psi to 300 psi range is,required for testing those valves.

To seek betcer direction on the type of facility that would best fit the Department of Energy (DOE) needs, a series of trade-off studies was conducted to compare the cost of a 250 psi facility with a 50 psi facility and to evaluate a new concept in heat exchangers that promised to reduce capital costs and operating costs significantly. 
3.1 Introduction to the Trade-0ff Studies

As shown in Figure 3-1, four systems were examined and compared in the trade-off studies: the 50 psig test facility using conventional design with state-of-the-art components was designated as the baseline design. A 250 psig design using the same stateof-the-art allowed comparisons to be made showing the effect of pressure level on facility design and cost. Similar designs using a heat exchanger employing recirculating media were conducted to show the benefits of the new technology.

\subsection{Simulation of Hot Dirty Gas}

All of the systems studied provided exact simulation of the fuel gas composition listed in the METC specifications along with the ability to match any future requirements of changing gas composition. The gas circulates continuously in the closed loop test facility.

Particle simulation is also exact as coal ash or char may be used in the systems. Particles are continuously introduced into the hot gas stream from a calibrated feeder which is used to measure their flow. The particles are distributed in the eight-inch hot gas line by passing through a diffuser section and heated by the hot gas while traversing a 14-foot straight length of pipe immediately upstream of the val,ve undergoing testing. The particles are removed from the gas stream downstream of the valve. At the test condition of 1750F, coal ash becomes sticky and tends to agglomerate. It can also change its chemical composition. Hence, since the ash undergoes such marked changes from exposure to the test environment, a once-through particulate system is a necessity if the test environment is to be rigidly controlled. Testing with an inert particulate would eliminate the problem but the degree of simulation with the real operating environment would be poor. 
FIGURE 3-1

SYSTEMS STUDIED

\begin{tabular}{|c|c|c|}
\hline & $\begin{array}{l}\text { CONVENTIONAL DESIGN } \\
\text {-StATE-OF-THE-ART } \\
\text { COMPONENTS }\end{array}$ & $\begin{array}{c}\text { Recirculating Media } \\
\text { - Combined Filter and } \\
\text { Heat Exchanger }\end{array}$ \\
\hline $\begin{array}{c}50 \text { PSIg SYSTEM } \\
\text { •CO-GAS }\end{array}$ & $C D-50$ & $R M-50$ \\
\hline $\begin{array}{l}250 \text { PSIG SYSTEM } \\
\text { - CO GAS } \\
\text { - COMBINED CYCLE } \\
\text { - PrESSURIZED FE }\end{array}$ & $C D-250$ & $R M-250$ \\
\hline
\end{tabular}


3.3 Design Criteria for All Systems

All systems were designed to meet the following criteria:

1. 8" ID Valves

2. $1650 \pm 100 F$ gas temperature

3. $175 \mathrm{ft} / \mathrm{sec}$ gas approach velocity

4. Gas Composition

\begin{tabular}{|c|c|}
\hline Component & Volume 8 \\
\hline $\mathrm{N}_{2}$ & $<0.1$ \\
\hline $\mathrm{H}_{2} \mathrm{~S}$ & 1.1 \\
\hline $\mathrm{H}_{2}$ & 44.0 \\
\hline $\mathrm{H}_{2} \mathrm{O}$ & 15.9 \\
\hline co & 25.3 \\
\hline $\mathrm{CO}_{2}$ & 12.7 \\
\hline $\mathrm{CH}_{4}$ & 0.9 \\
\hline
\end{tabular}

Average molecular weight $=16.93$

5. Valve turn down $2: 1$

6. $\triangle P$ while open: 108 of the upstream pressure

7. 15 seconds cycle time

8. 8000 hours per year testing

9. Solids loading 0.68

10. Particle Size Distribution

\begin{tabular}{cc}
\multicolumn{1}{c}{ Size } & Weight 8 \\
$<0.1 \mu$ & 1 \\
$0.1-1 \mu$ & 9 \\
$1-5 \mu$ & 39 \\
$5-10_{\mu}$ & 40 \\
$10-60_{\mu}$ & 11 \\
$>60 \mu \mu$ & 0
\end{tabular}


Figure 3-2 presents a schematic diagram of the Conventional Design Valve Test Loop: Starting at the upper left of the diagram, particulate is introduced into a calibrated particle feeder through a locked hopper arrangement. The feeder itself is contained in a pressure tight enclosure which is flooded with fuel gas at a pressure slightly above the system pressure at that location. Particle feed rate is controiled by varying the speed of the feeder by electrical means.

Particulate is introduced into the main gas stream by a single tube exhausting into the throat of a $2: 1$ area ratio venturi in the main gas flow line. The pressure reduction at the throat of the venturi assures a positive flow of fuel gas along with the particulate into the mainstream. Turbulent flow through the diffusing section of the venturi mixes the particulate with the gas stream. The hot fuel gas containing the particulate flows 14 feet through a straight section of pipe before encountering the test valve. The straight section of pipe is required to prevent any accumulation of sticky particulate on the pipe walls.

The test valve is contained in an insulated pressure container of adequate integrity to retain the hot fuel gas in the event of a rupture of the valve body. Shut-off valves upstrean and downstream of the test section allow the test valve to be changed without de-prcsourising the system. METC Type III lonked hopper valves are used for this purpose.

Downstream of the test valve a refractory lined cyclone is used to separate approximately 70 per cent of the particulate, leaving only the smallcot partioulate in the gas stream. A continuous two per cent bleed from the cyclone carries the particles to the baghouse. The transfer line is finned and cools the gas by radiation and convection with the surroundings. The valve controlling the flow operates with cool gas.

The main stream of gas leaving the cyclone goes to a regenerator where it is cooled by passing over tubes containing fuel gas which is being heated on its way to the test valve. The tubes used in the regenerator would corrode rapidly if they were to operate at 
FIGURE 3-2 FLOW SCHEMATIC - CONVENTIONAL DESIGN APPROACH

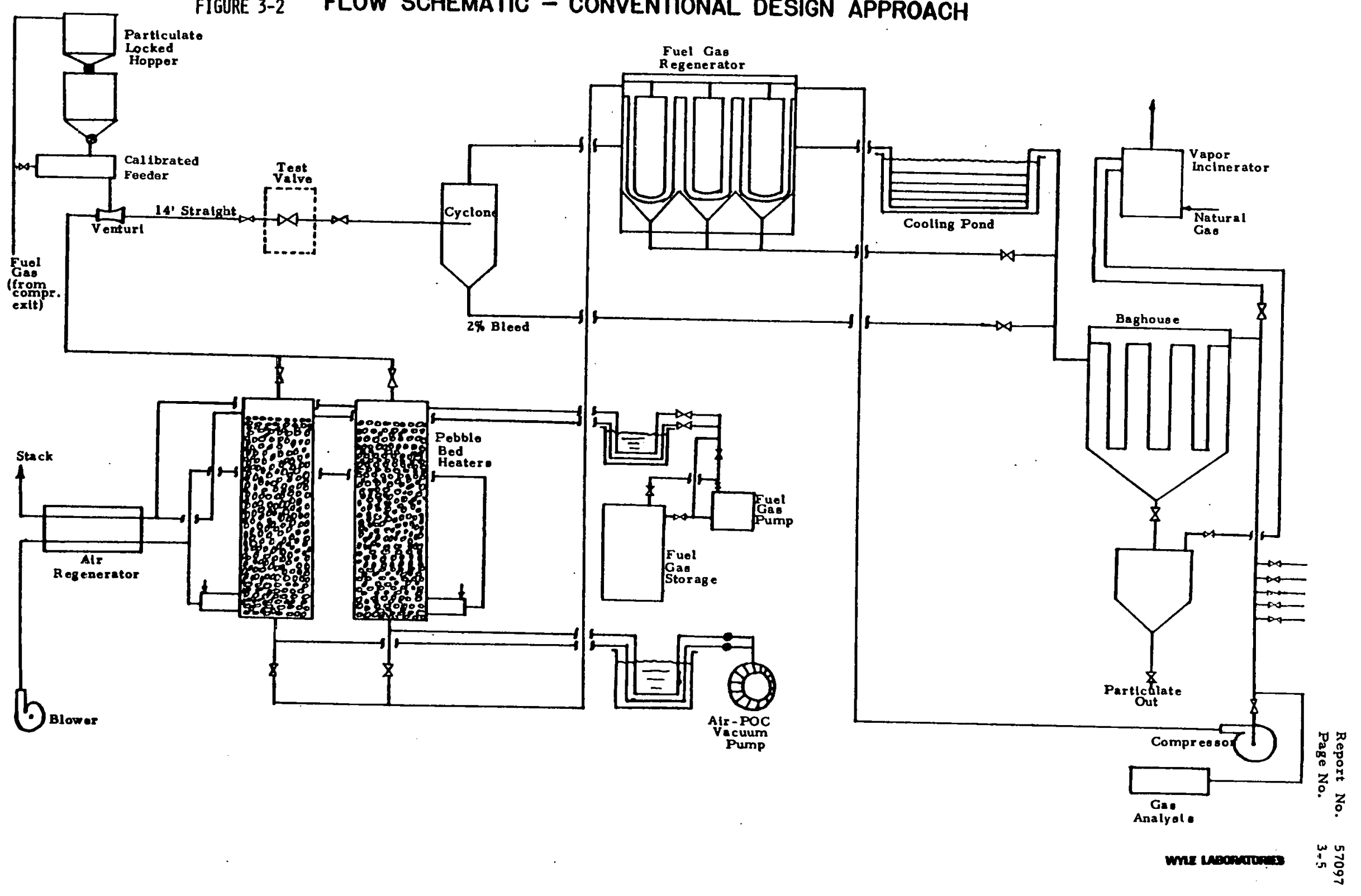


$3-6$

3.4 (continued)

the full gas temperature of 1750F. The maximum tube temperature was set at approximately 1400F, limiting the maximum temperature of the reheated fuel gas to $1200 \mathrm{~F}$. As a result of this limitation only a portion of the heat of the incoming gas can be transferred to the gas being heated. Consequently the temperature of the dirty gas exiting trom the seyenerator in apprnximately $800 F_{;}$ it must be further cooled before introduction to the baghouse and later the compressor. This is accomplished by passing the gas through tubes in a cooling pond and boiling away a portion of the water in the pond.

A portion of the particulate in the gas stream will be deposited on the tubes of the regenerator and remain within the regenerator. This material is periodically removed and carried to the baghouse through a bleed line. Again fins on the line cool the gases in transit to the baghouse. The particulate leaving the baghouse is removed through a locked hopper.

The gas leaving the cooling pond is perhaps $250 \mathrm{~F}$ and passes through a baghouse where essentially all of the particles are collostod. The fuel gas, free of all but some submicron particles is directed to the compressor where it is recompressed. Cooling the gas to approximately 200F rather than allowing 1t to remain at 6005 (baghouse temperatuxi $I i m i+$ ) nubstantially reduces compressor power requirements and allows the use of standard off-the-shelt compressor.

For venting the system, the vent line is connected to the incinerator to burn the fuel gas before release to the atmosphere. The vents from the locked hoppers are similarly connected to the vapor incinerator.

To fill the system, a vacuum of $1 / 4$ pgia is established in the system and make-up gas is introdiced component by component from separate storage vessels until the desired mix and pressure level is achieved. The composition of the gas in the loop is continuously monitored by a mass spectrometer using data processing techniques. Make-up gas can be supplied during test loop operation. 
Downstream of the compressor the fuel gas passes first through the tubes of the regenerator (to be heated to perhaps 1200F) before it is introduced to the pebble bed heaters for final heating to 1750F. Each of the two pebble beds alternates between heating the fuel gas and being heated itself by means of the exhaust from the natural gas burner. To save energy, the 1200F exhaust from the chamber being heated passes through a regenerator to preheat the incoming air to the burners.

Prior to switching from the pebble heating cycle (using the natural gas burner) to heating the fuel gas, the residual products of combustion are withdrawn from the vessel using a vacuum pump. similarly, prior to switching in the other direction, the fuel gas is evacuated from the vessel and stored.

3.5 Gas Elow Rate Parameters for Conventional Systems

The flow of fuel gas about the test loop was calculated for both the 50 psi case and the 250 psi case. For each pressure level, the steady state flow was calculated for both the case with the valve wide open and the case with the valve in the half flow position. The former case sized the heat transfer equipment while the latter case sized the compressor.

Figures 3-3 and 3-4 present the flow parameters for the $C D 50$ design; Figures $3-5$ and 3-6 present the flow parameters for the CD 250 design.

3.5 Component Design Features for the Conventional System

3.6.1 Hot Gas Piping Design

Figure 3-7 presents a sketch of the design concept for the hot gas piping. A mild steel outer shell was used to withstand the pressure forces. Insulating refractory is cast into the pipe held in place by metal hangers. A lining of hard refractory castable is cast over the insulating refractory to withstand the erosion and corrosion from the particles in the flow. 
FIQRE 3-3 FLOW SCHEMATIC - CONVENTIONAL DESIGN APPROACH

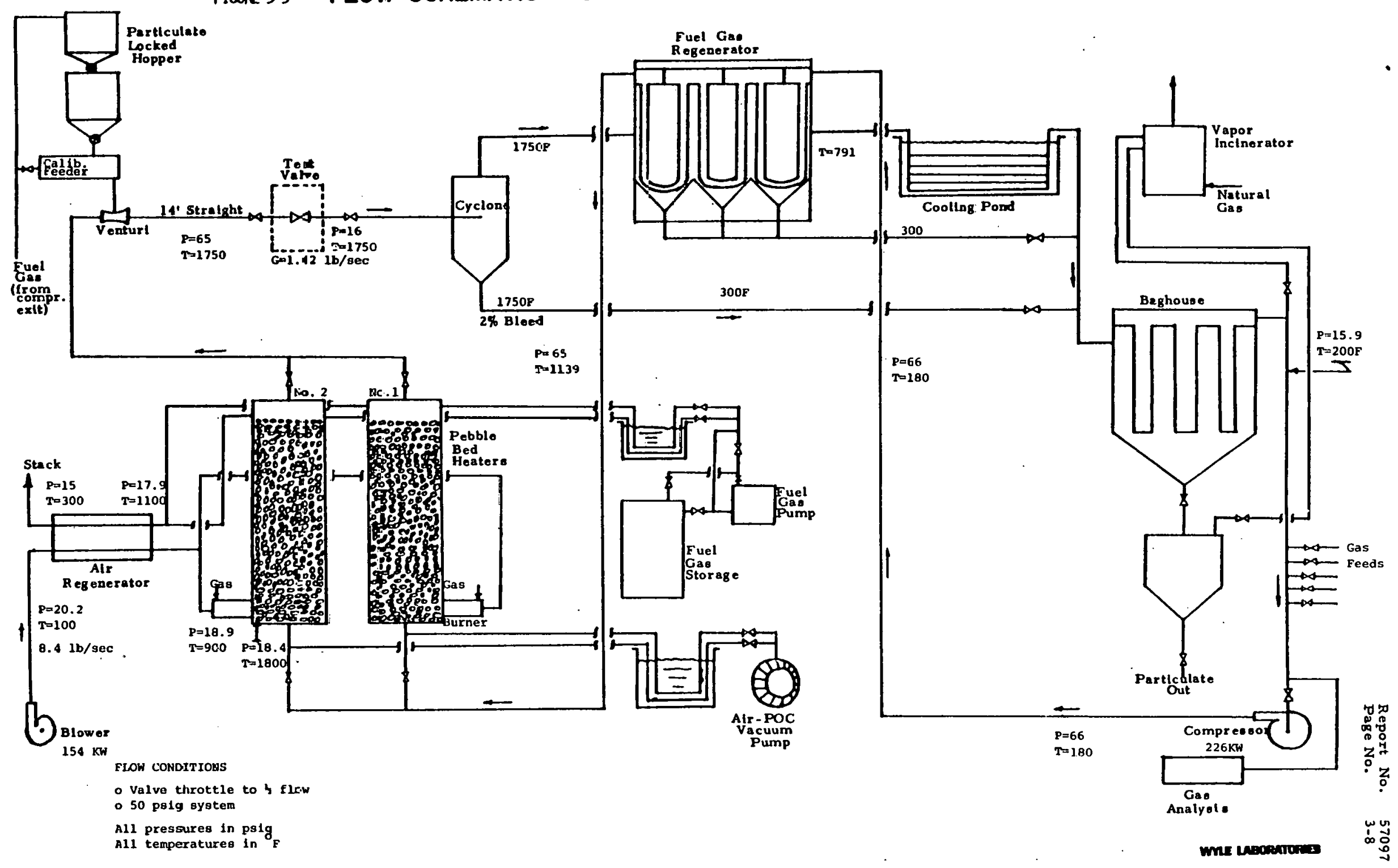


FIGUFE 3-4 FLOW SCHEMATIC - CONVENTIONAL DESIGN APPROACH

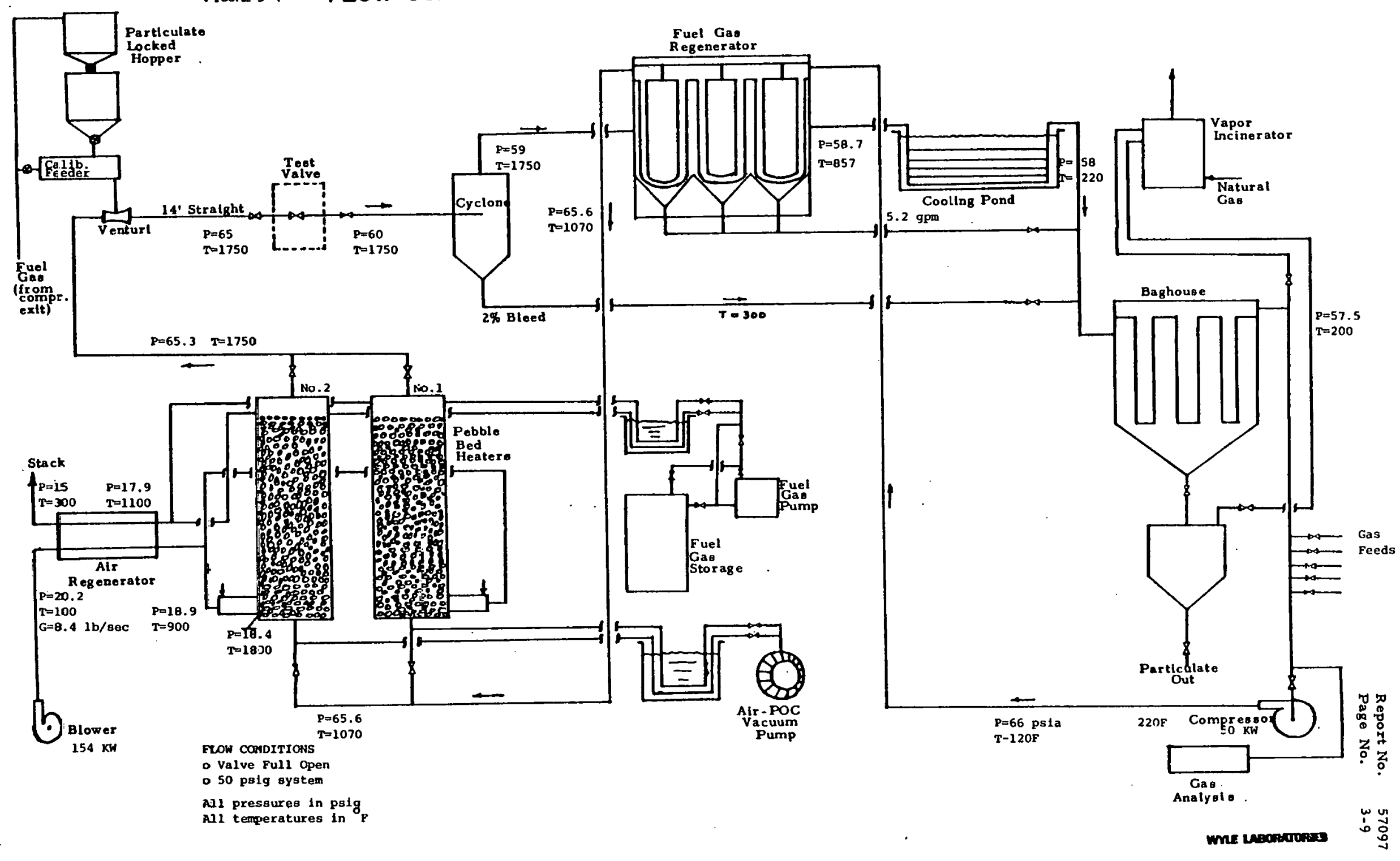


FIGUPE 3-5 FLOW SCHEMATIC - CONVENTIONAL DESIGN APPROACH

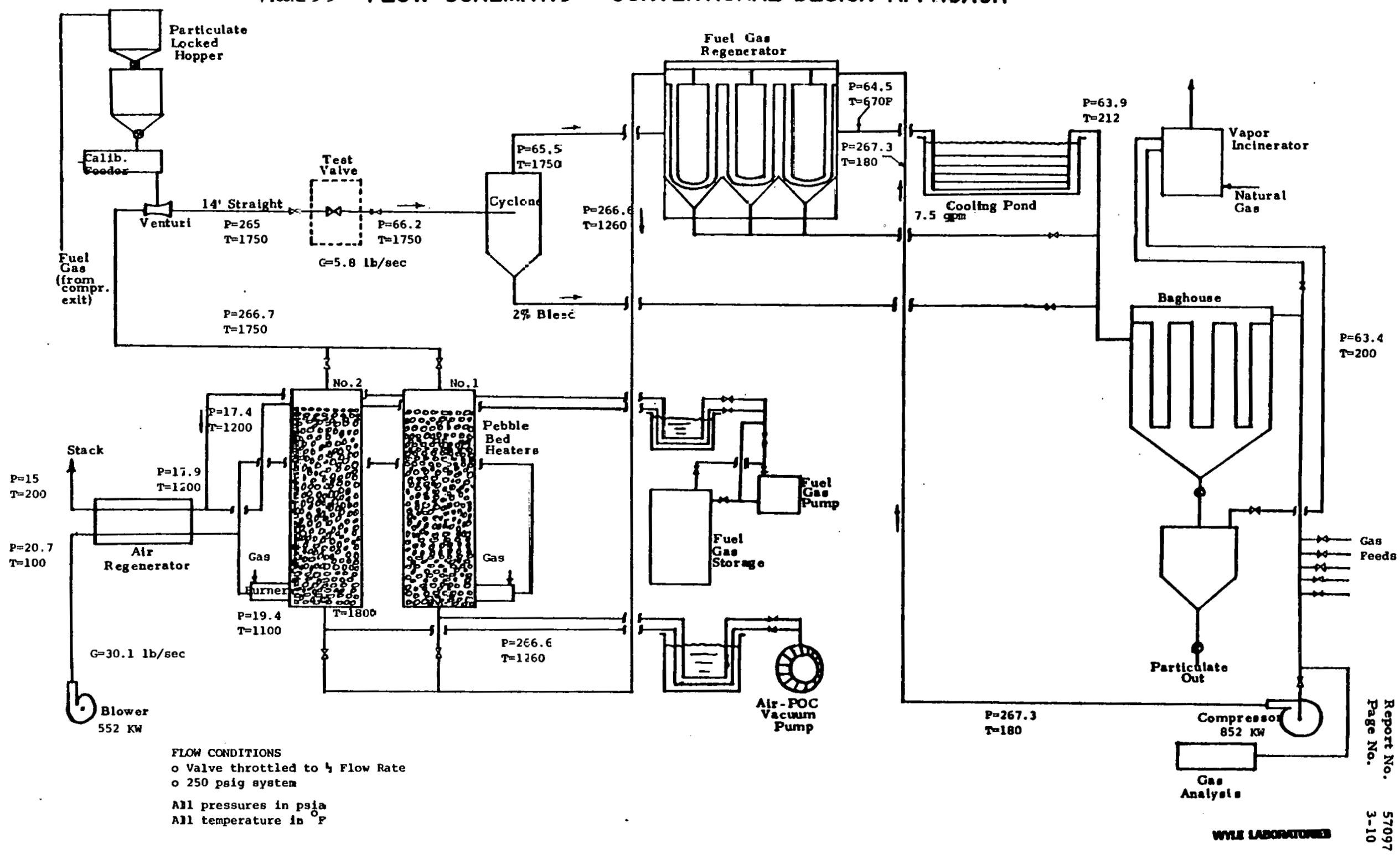




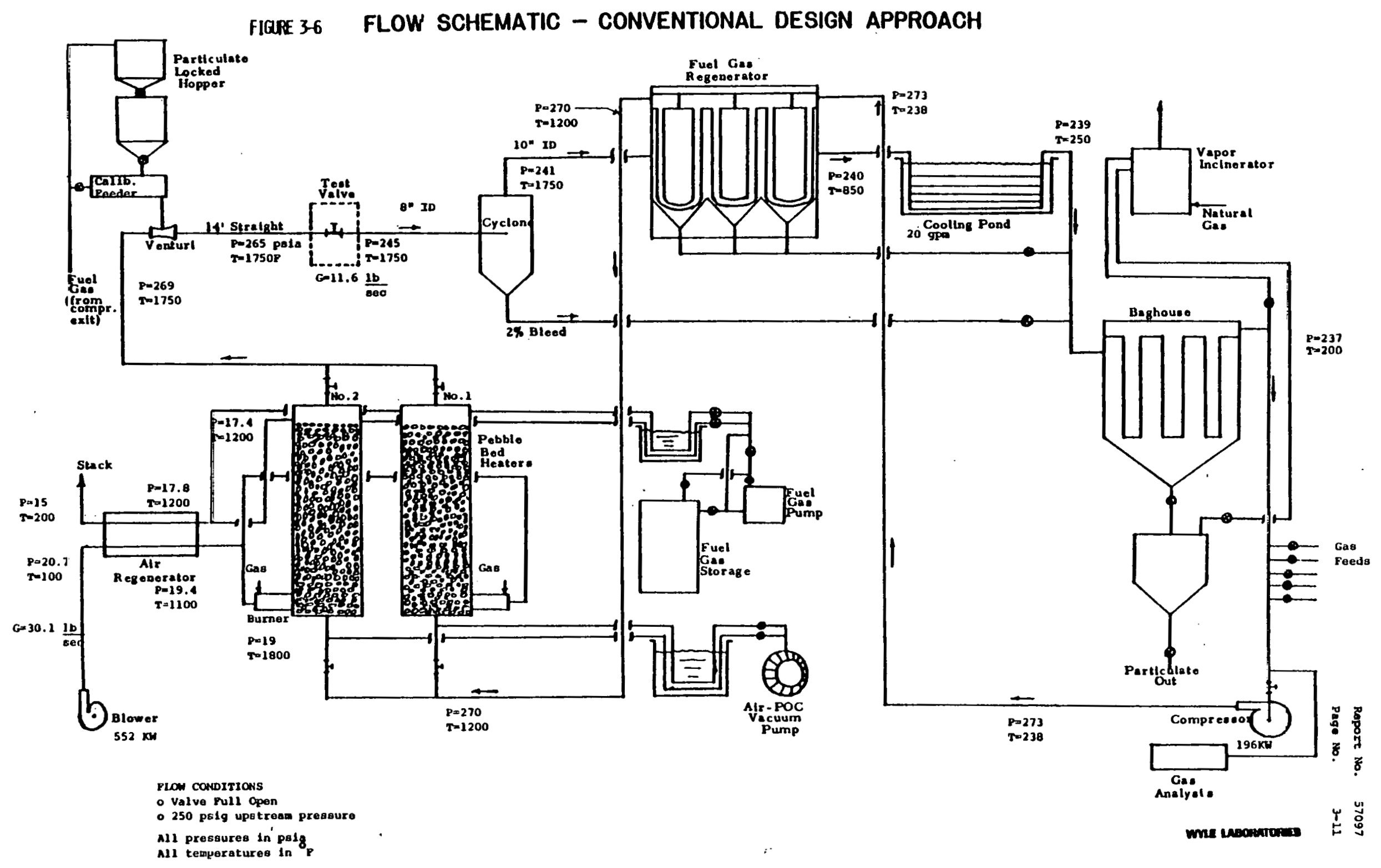




\section{FIGURE 3-7}

\section{HOT PIPING DESIGN}

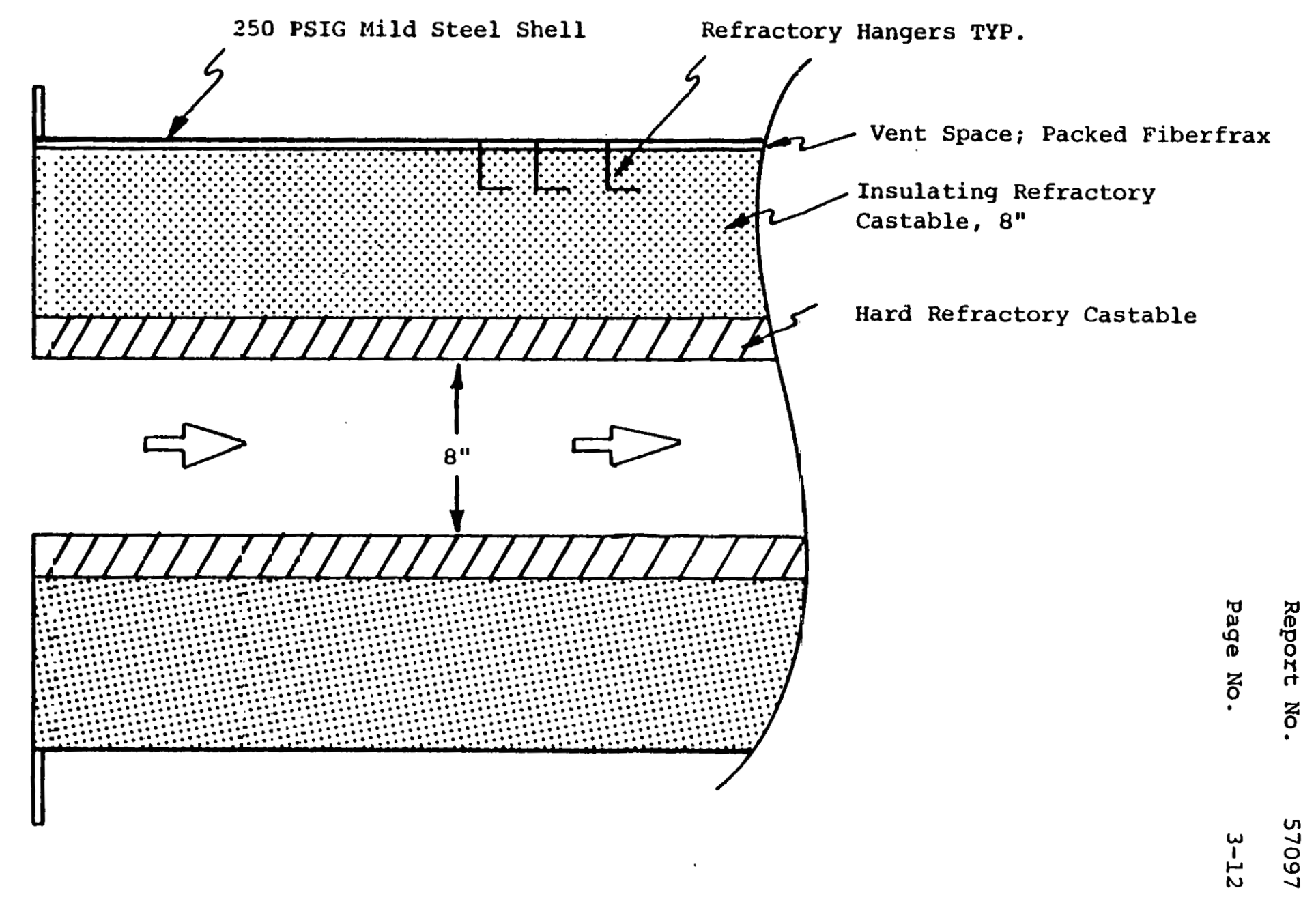


Figure 3-8 presents a sketch of the cyclone for the CD-250 system. Its construction is similar to the hot gas piping in that a mild steel outer shell is used to react the pressure forces and refactory is cast into the mild steel shell.

3.6.3 CD-250 Fuel Gas Regenerator

Figure 3-9 presents a sketch of the fuel gas regenerator for the CD-250 system. The heat exchanger itself is mounted within a cylindrical pressure vessel to contain the 250 psig system pressure. The hot dirty gas from the cyclone enters the regenerator and flows downward through a $2^{\prime} \times 2.5^{\prime}$ gas channel in which are mounted two-inch $O D$ tubes on four-inch centers. Upon reaching the bottom of the channel, the gas turns and flows upward through the adjacent channel. In all, four channels are provided. Clean fuel gas which is being heated flows through the tubes countercurrent to the flow of hot dirty gas.

The hot dirty gas entering the regenerator will deposit substantial amounts of dirt on the surfaces of the tubes. This dirt is removed periodically by showering steel shot down the hot gas passages over the tube surface. The shot is removed with the ash and, after cooling, is separated for reuse by a mechanical screen.

The regenerator contains the following tubing:

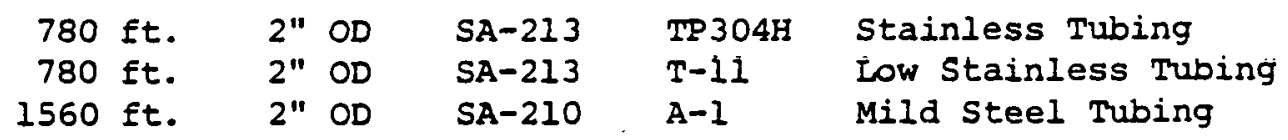

Tue tube spacing used in the design of the regenerator is typical for a coal-fired boiler, which has a similar ash accumulation problem. 
FIGURE 3-8

\section{CD-250 CYCLONE}

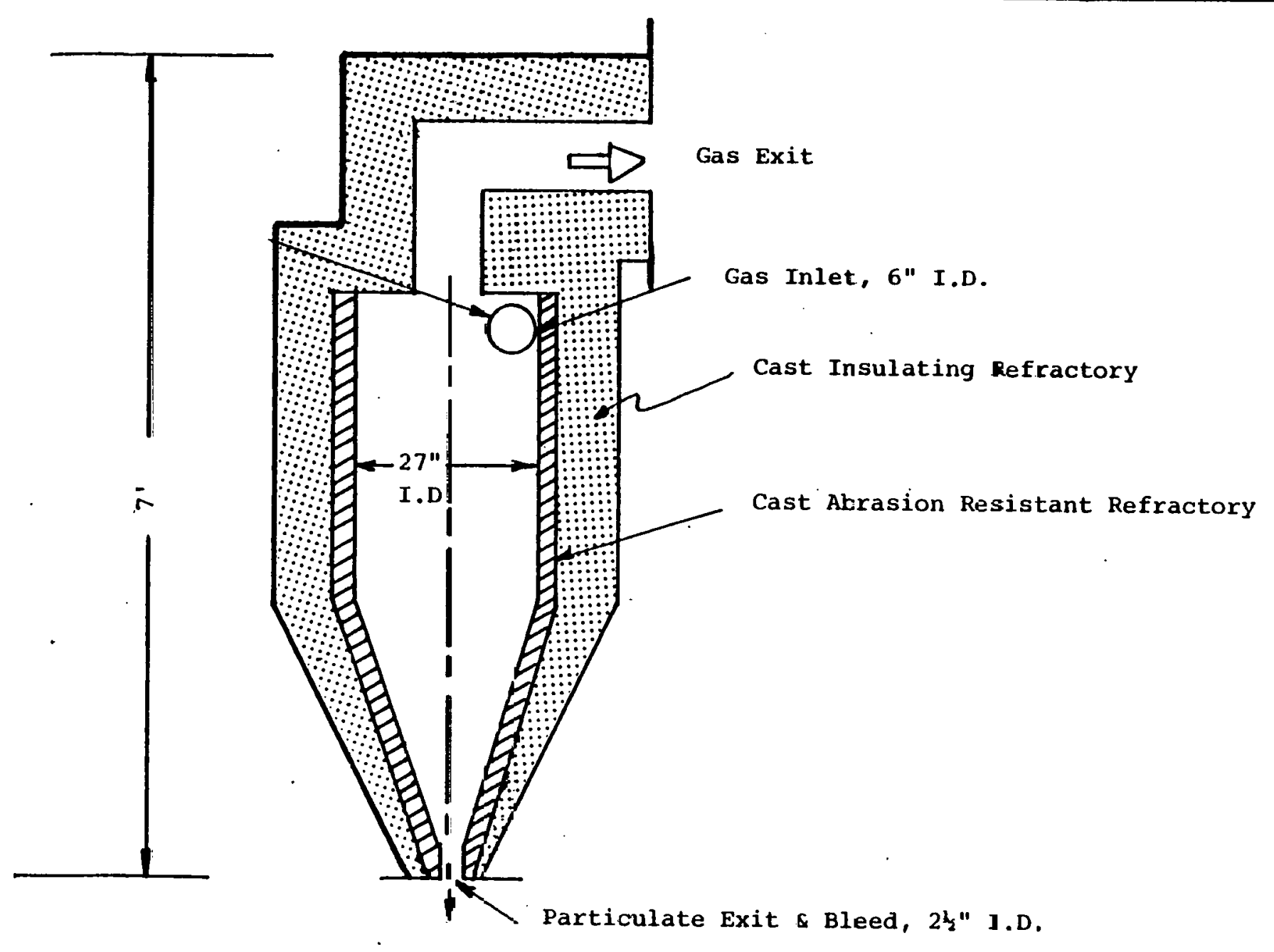




\section{FIGURE 3-9 \\ CD-250 FUEL GAS REGENERATOR}

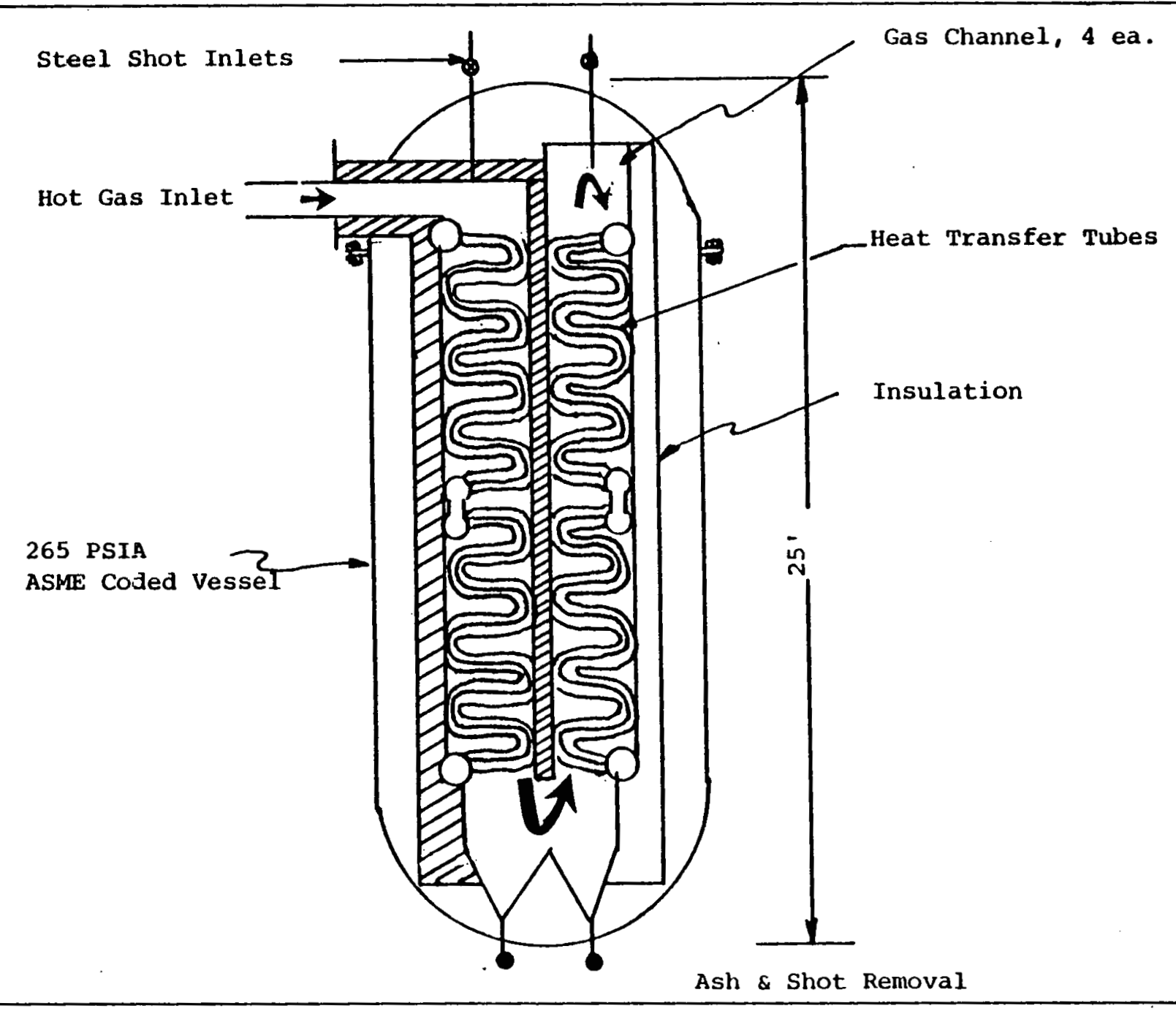




\subsubsection{CD-250 Evaporative Pond}

Figure 3-10 presents a sketch of the evaporative pond used to cool the fuel gas from approximately $800 \mathrm{~F}$ to $250 \mathrm{~F}$. The hot gas is passed through two-inch OD mild steel piping; heat is removed by boiling the water in the pond. The pond is three feet deep. At fuld system flow, the pond evaporates $20 \mathrm{gmm}$ of oity water.

3.6.5 CD-250 Baghouse

Figure 3-11 presents a sketch of the CD-250 baghouse which is used for particle collection. Again a mild steel pressure vessel is used to withstand the pressure forces. The vessel is lined with a low temperature insulation to prevent condensation of the water vapor in the fuel gas at low temperatures.

A conventional baghouse structure is mounted within the pressure vessel. Low temperature fiberglass bags are employed for cost savings.

In the design of the baghouse, a conservative velocity of the gas through the cloth bag was employed, namely one foot per minute. As a result, efficiencies of over 99 per cent are obtained with moderate pressure drops.

3.6.6 CD-250 Pebble Bed Heater

Figure 3-12 presents a sketch of the pebble bed heater, two of which are required. It is composed of a mild steel pressure shell insulated with castable refractory. For the pebble heater a hard refractory inner facing is not required because the pebbles are stationary and the gas velocities are low. Also, the gas is essentially free of particulate.

The pebbles are supported on brick checkers. The checkers allow the entering gas to be distributed uniformly below the body of pebbles before the gas flows through the pebble bed itself. 
FIGURE 3-10

\section{CD-250 EVAPORATIVE POND}

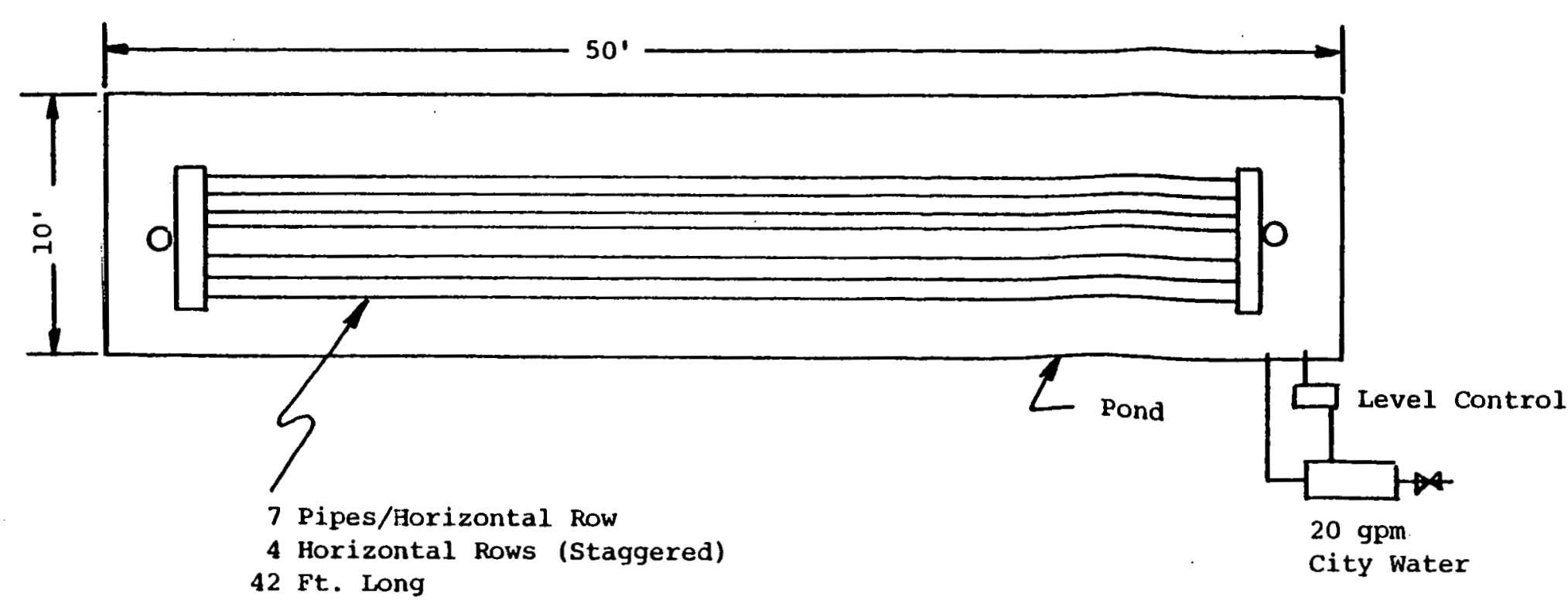


FIGURE 3-11

\section{CD-250 BAGHOUSE}

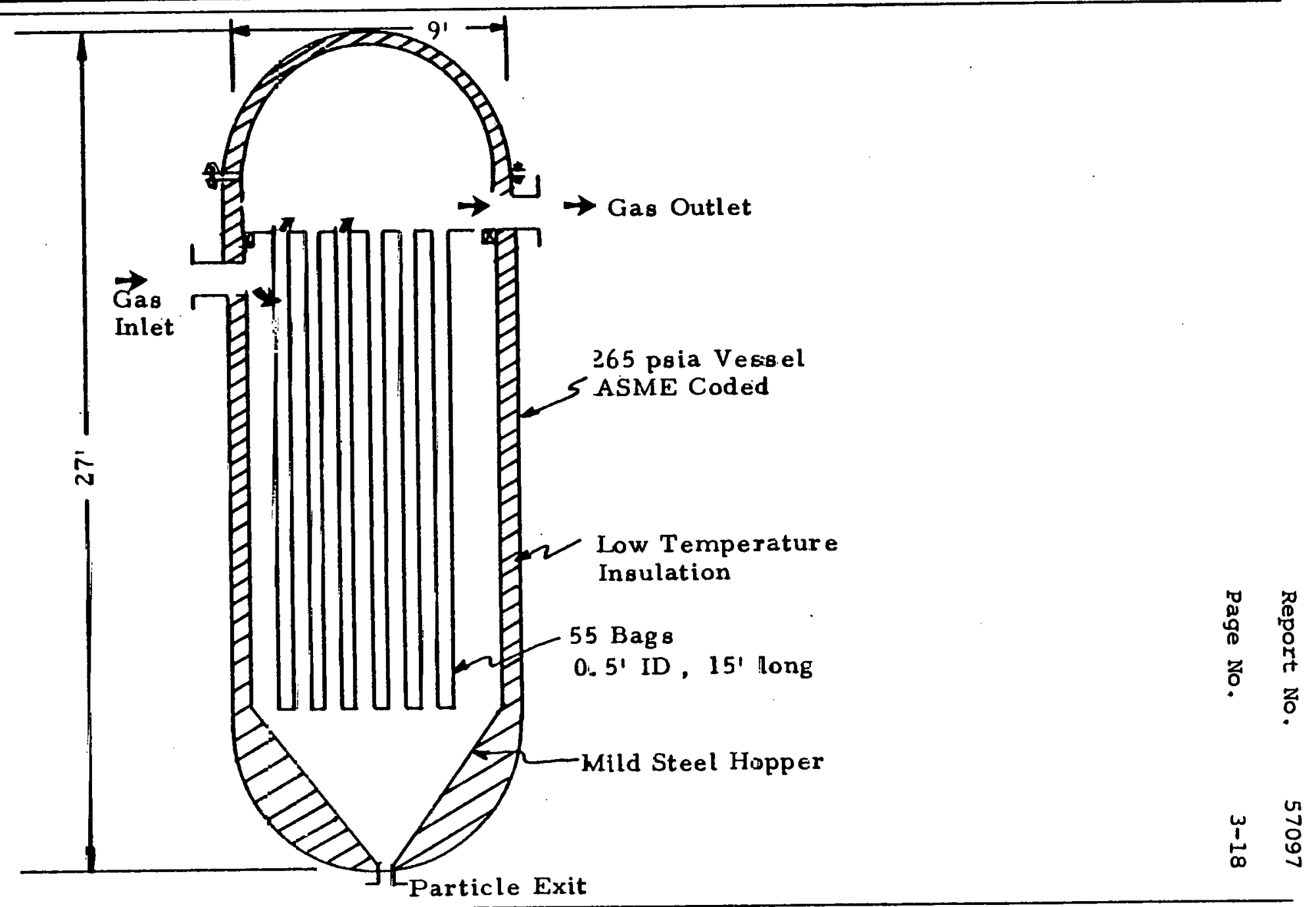




\section{FIGURE 3-12 \\ CD-250 PEBBLE BED HEATER}

(TWO REQUIR ED)

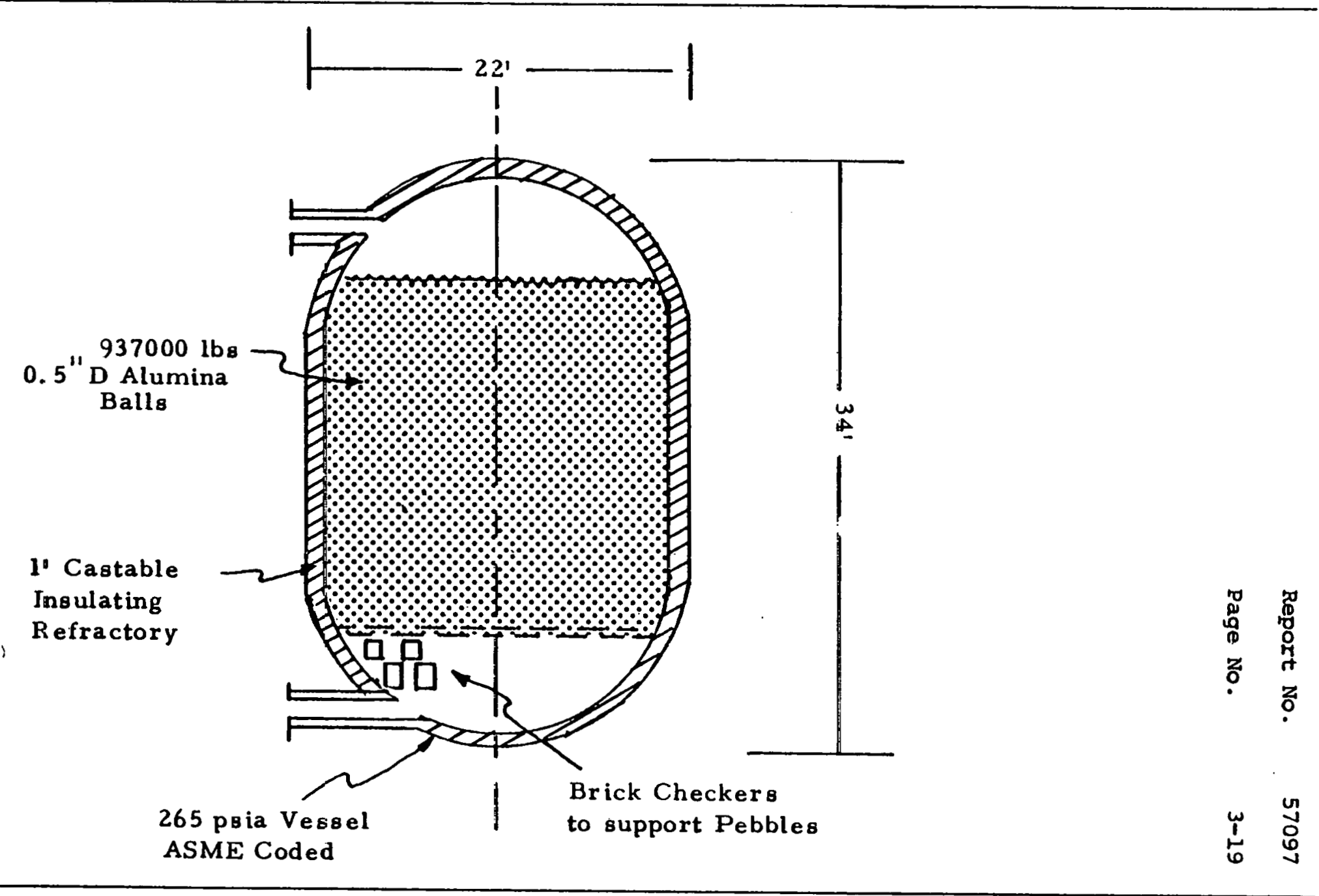




\subsubsection{CD-250 Air Regenerator}

Figure 3-13 presents a sketch of the CD-250 air regenerator, which is used to preheat the air to the burners for heating the pebble bed. The regenerator is composed of six vertical gas passages in which are mounted vertical air tubes. Baffles cause the exhaust gas to flow back and forth across the tubes.

3.6.8 CD-250 Overall Size

Figure 3-14 presents a sketch showing the size of the major components of a CD-250 system.

3.7 Energy Summary for the Conventional Systems

Figure 3-15 presents the energy summary for both the CD-50 and CD-250 systems. To make an overall comparison between systems on a total fuel basis, the electrical power was converted to fuel BTU's assuming a central power station efficiency of 30 per cent. As seen in the figure, the CD-250 system consumes about four times the energy of the $C D-50$ system. 
FIGURE 3-13

\section{CD-250 AIR REGENERATOR}

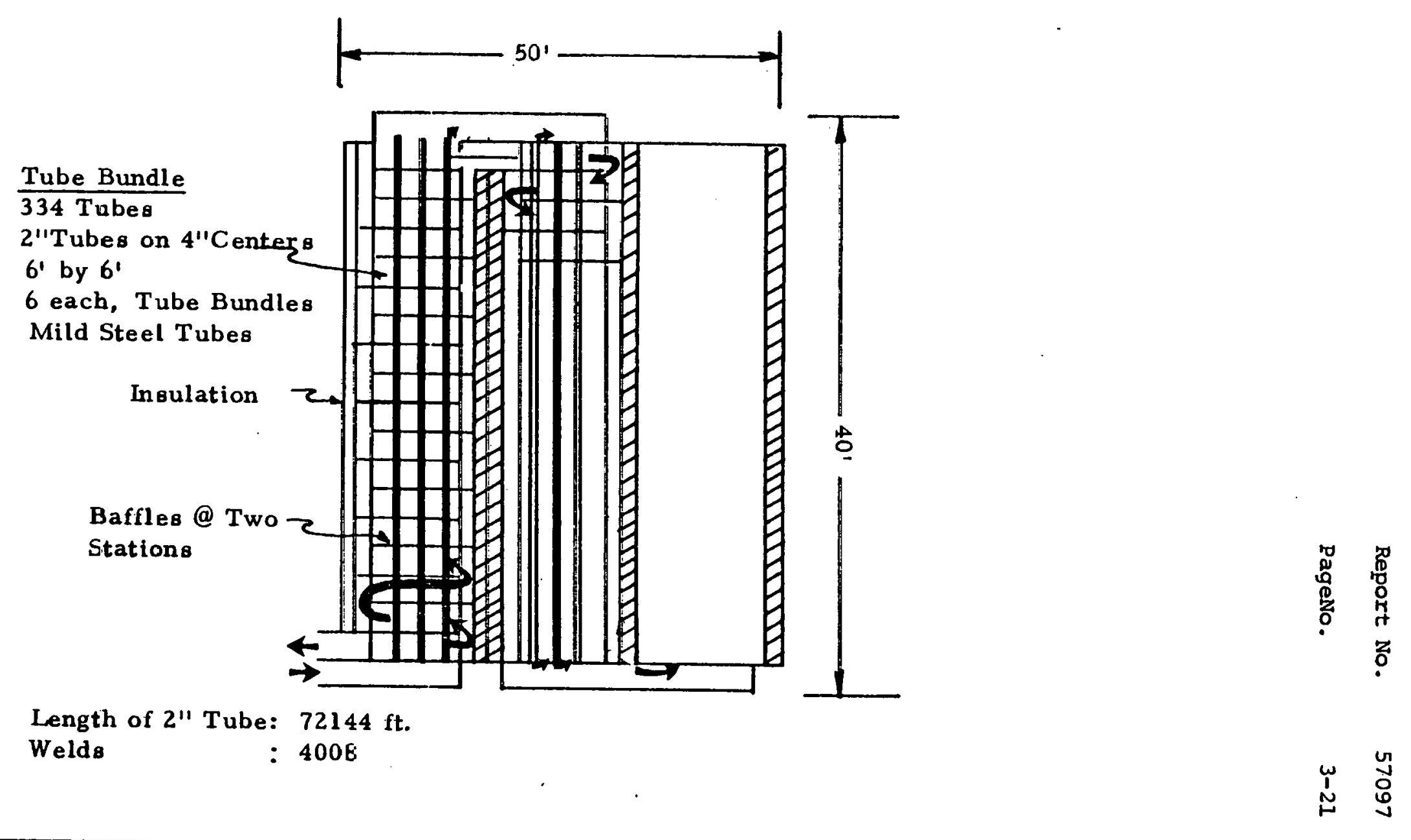


FIGURE 3-14

CD-250 - OUTLINE OF MAJOR COMPONENTS

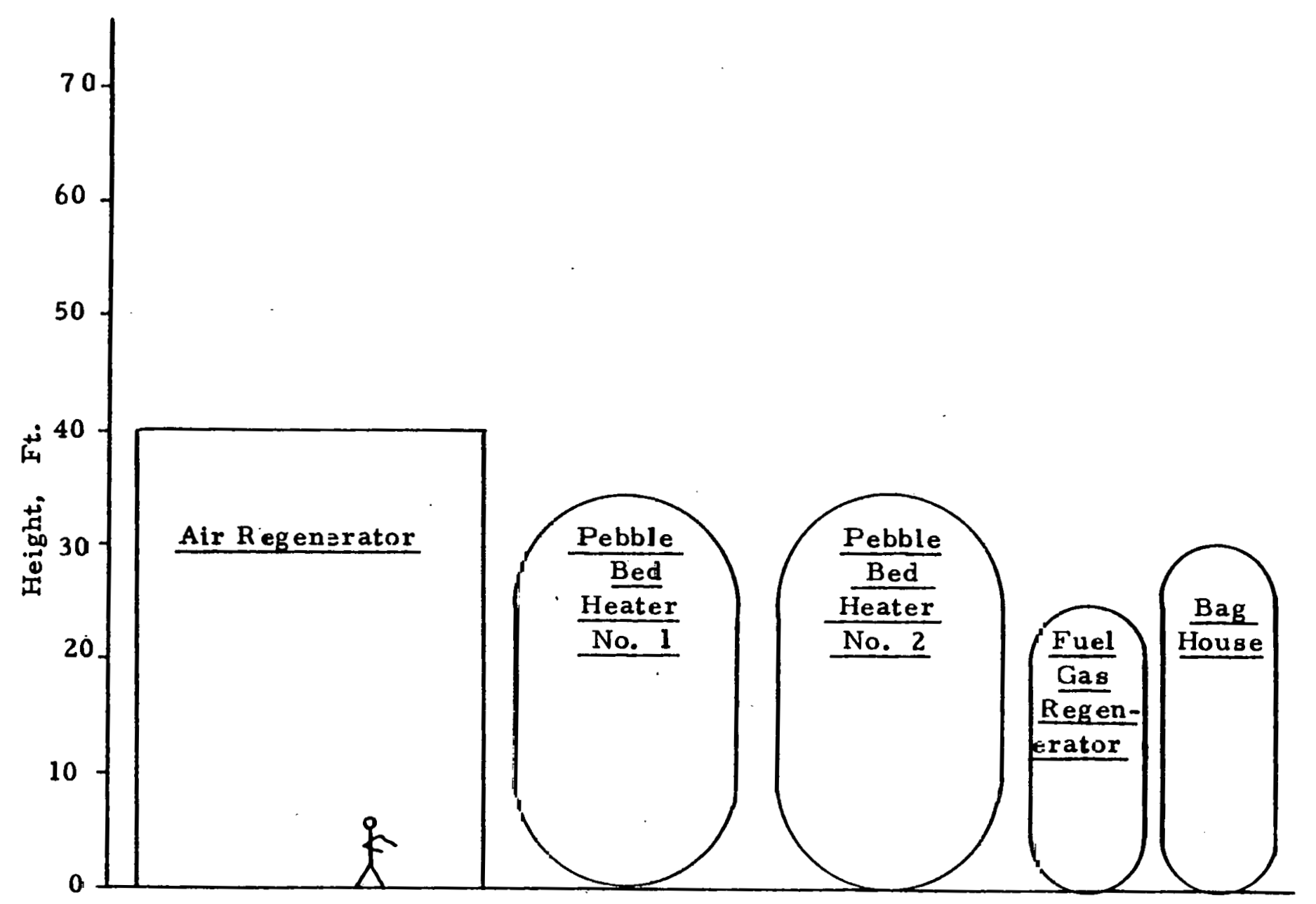




\section{ENERGY SUMMARY - CONVENTIONAL SYSTEMS}

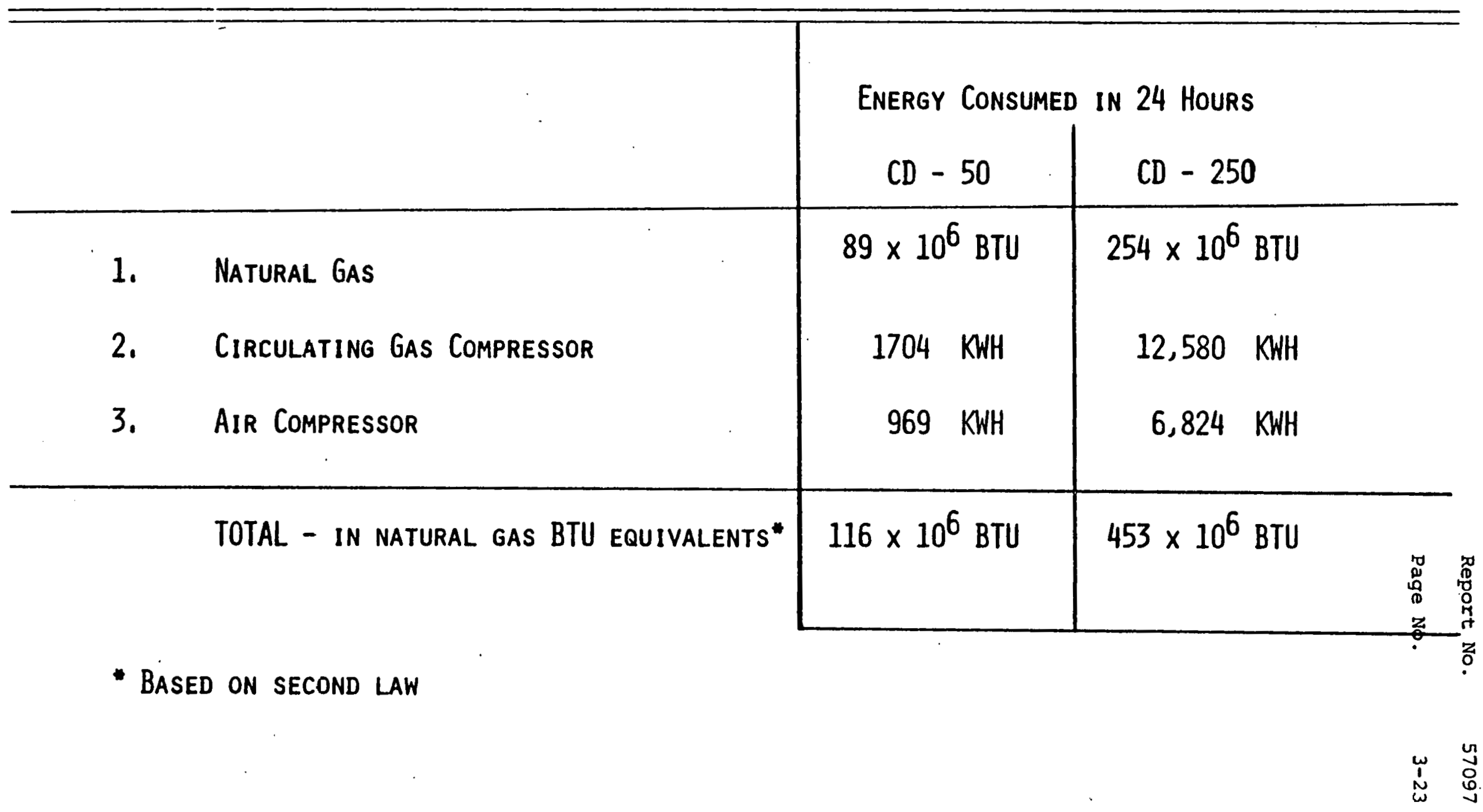


PAGE NO

$3-24$

\section{General Description of Recirculating Media System}

Figure 3-16 presents a schematic diagram of the recirculating media system. The major change between this system and the conventional design system is the manner in which heat is recovered from the fuel gas downstream of the test valve and reintroduced to the fuel gas after compression. The recirculating media system removes the limitation on the metal temperature of the conventional regenerator by transferring heat by recirculating refractory media, hence, a considerably greater amount of heat can be transferred. Alumina spheres 1/4-inch in diameter are used as the recirculating media. In addition to transferring the heat, the passage of the gas through the media removes most of the particulate matter from the gas, precluding the need for a large baghouse.

The recirculating media heat exchanger is a development of the Thermo Energy Corporation of Palo Alto, California who have filed patent applications covering its technology. Thermo Energy Corporation is currently building a 1900F recirculating media heat exchanger for application to die cast furnaces.

Referring again to Figure 3-16, the particle feed subsystem, the test valve arrangement and the cyclone are identical to the conventional desion systems. Leaving the cyclone the hot dirty gas enters the heat recovery section of the resirculatiriy aedia heat exchanger. The hot gas is distributad into the bottom of the cylindrical vessel filled with 1/4-inch diameter spherical media manufactured from alumina. The hot gas flows upward through approximately five feet of the media and is cooled from $1750 F$ to approximately $200 F$ in passing through the media. The media itself is flowing downward and at the same time being heated by the hot gas. Particulate matter remaining in the hot gas is trapped by the contact with the media. cleaned and cooled fuel gas leaves the heat recovery section and is piped to the compressor inlet.

Hot media at $1730 F$ is continuously drained from the heat recovery section into the media heating section through a short seal leg. In the media heating section the media is heated to 1770 f by passing a 2500 gas flow from the propane burner through the 
FIGPE 3-16 FLOW SCHEMATIC-RECIRCULATING MEDIA APPROACH

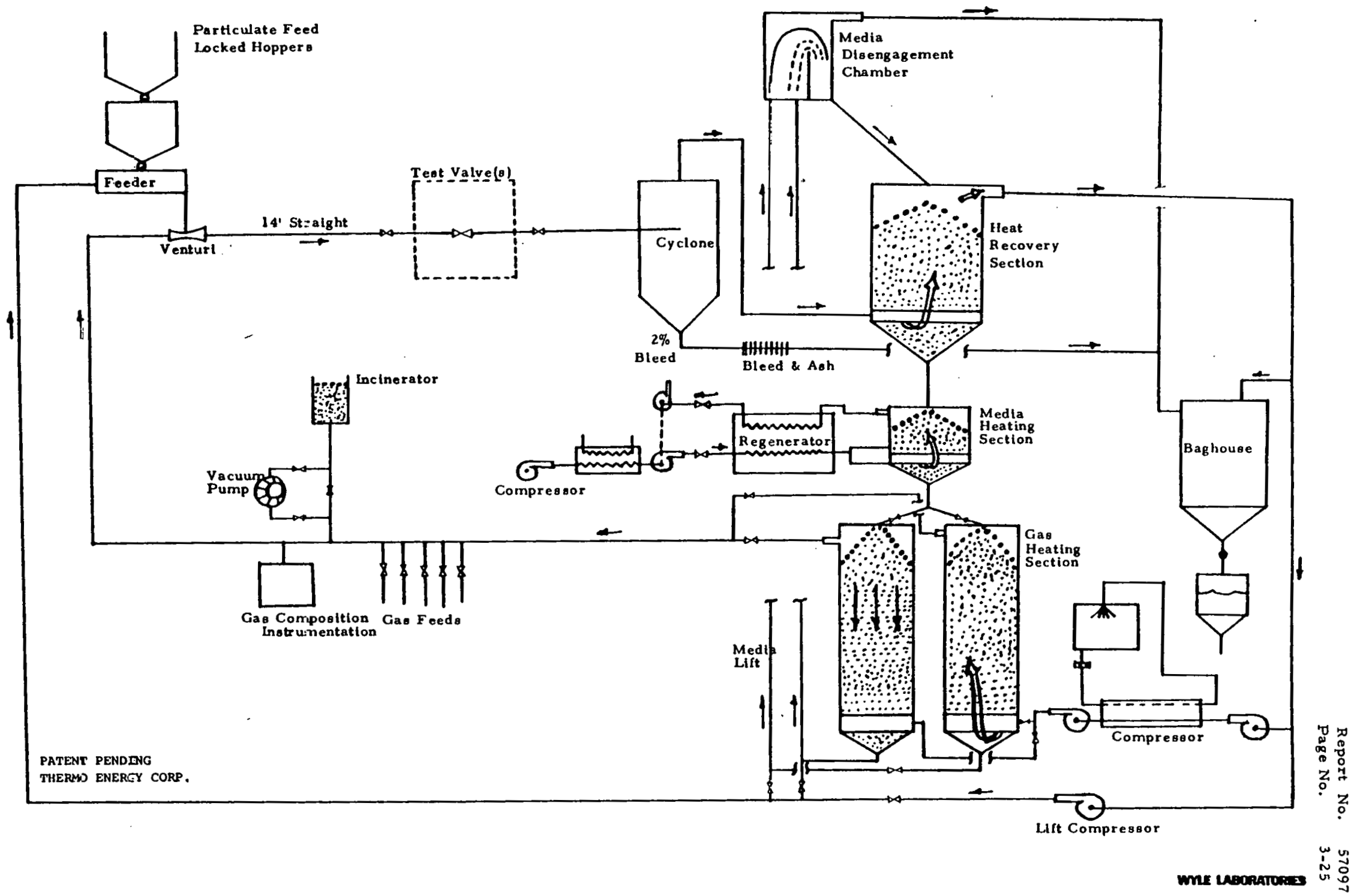




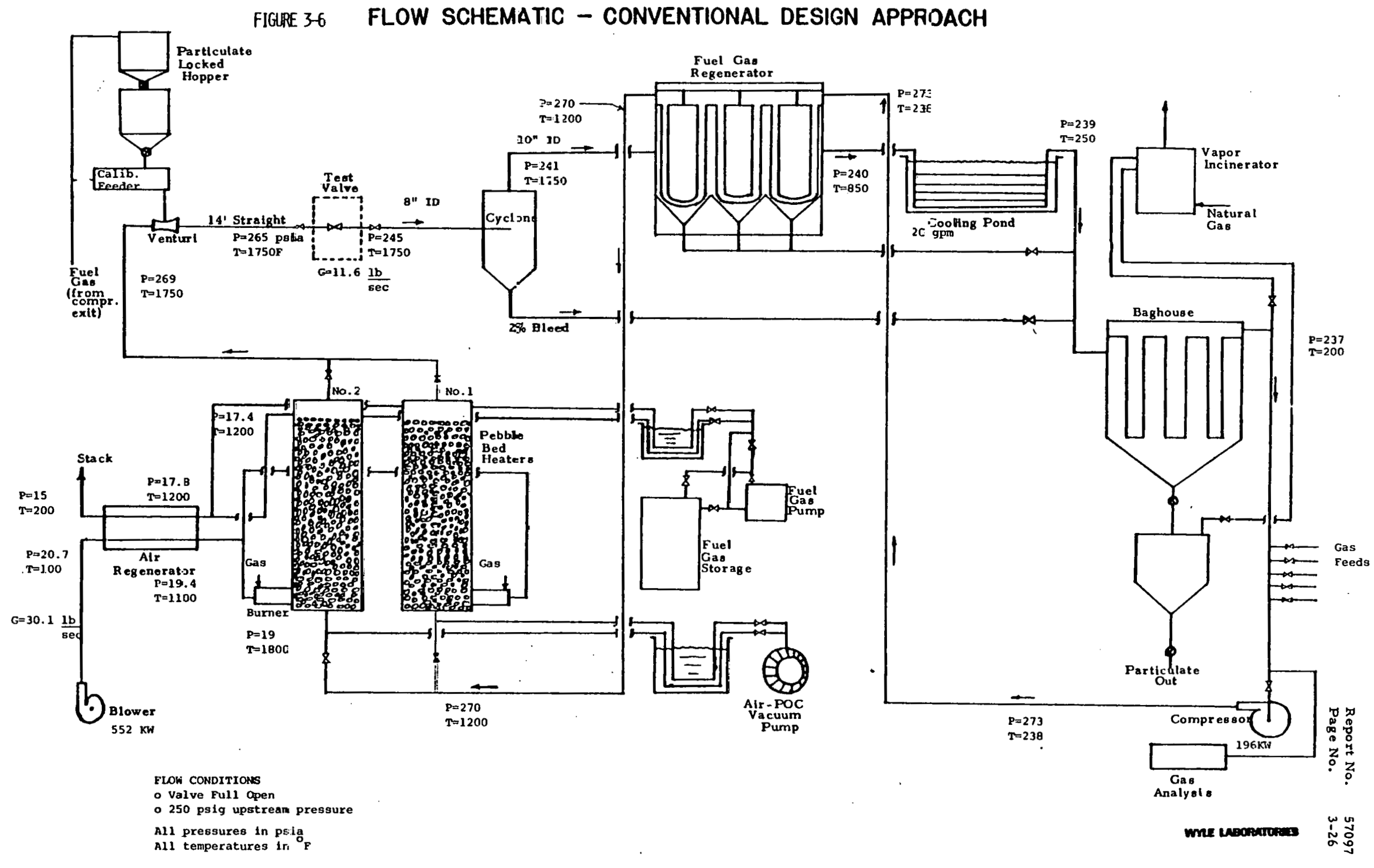


PAGE NO

$3-26 a$

media. The exit gas from the media heating section leaves at 1750F. The media heating section is maintained at the same pressure level as the heat recovery section to prevent mixing of the fuel gas in the test loop with the products of combustion from the propane burner. The seal leg is employed to restrict the flow of gas for small differential pressures.

The media flowing from the media heating section flows into one of two vessels in the gas heating section. As shown in Figure 3-16, the left vessel is filling with hot media while the right vessel is heating fuel gas with the hot media earlier charged to it. Returning to the vessel filling with media, cooled media is continuously withdrawn from the bottom of the vessel causing the media to flow through the heat recovery section and the media heating section. Media withdrawn from the gas heating vessel is lifted to the metal disengagement chamber by means of a gas lift using fuel gas from the test loop. A separate lift compressor is supplied.

The media leaving the hopper of the gas heating vessel still has the particulate entrained with it but has cooled from $1750 \mathrm{~F}$ to perhaps 185F. As it is lifted by the high velocity gas, the particulate is dislodged from the media and becomes entrained in the gas stream. In the media disengagement chamber the media is separated from the dirty gas and returned to the heat recovery section. The dirty gas is directed to the baghouse along with the bleed from the cyclone.

The main recirculating compressor is a two-stage unit with full intercooling using water with an evaporative cooling tower to dissipate the heat. The high pressure gas leaving the compressor passes through one of the two gas heating vessels where it is heated to $1750 \mathrm{~F}$ by the hot media. This higher pressure vessel is isolated from the lower pressure media system by means of a 1750F Type III valve. Switchover between the vessels occurs every two hours. 
PAGE NO $3-27$

The flow of fuel gas around the test loop was calculated for both the $50 \mathrm{psi}$ case and the $250 \mathrm{psi}$ case. For each pressure level the steady state flow was calculated for both the case of the valve wide open and the case with the valve at the one-half flow position. The former case determined the size of the heat transfer equipment while the latter case determined the size of the compressor.

Figures 3-17 and 3-18 present the flow parameters for the RM-50 system; Figures $3-19$ and 3-20 present the flow parameters for the RM-250 system.

3.10 Component Design Features for the Recirculating Media Subsystem

3.10.1 RM-250 Heat Recovery Section

Figure 3-21 presents a sketch of the heat recovery section of the RM-250 system. As mentioned earlier, the heat transfer media used in the system are 1/4-inch diameter spheres made from alumina. The heat recovery section has an internal diameter of five feet and a length of 26 feet, including the media seal leg. As shown in the figure, cool media enters from above at $185 \mathrm{~F}$ and leaves from the seal leg at 1730F. The hot dirty gas at. $1750 \mathrm{~F}$ is distributed into the media by means of ceramic channels. The gas leaves the channels and flows upward through approximately five feet of media.

The heat recovery section is a mild steel pressure vessel lined with castable refractory. The majority of the lining is insulating refractory with a hard face refractory cast un the inner surface to withstand the abrasion of the media. Approximately 26,000 pounds of media are contained in the heat recovery section.

3.10.2 RM-250 Media Heating Section

Figure 3-22 presents a sketch of the media heating section. Its design is similar to the heat recovery section but is is considerably smaller in size, holding only 211 pounds of media. 
FIGHE $3-17$ FLOW SCHEMATIC-RECIRCULATING MEDIA APPROACH

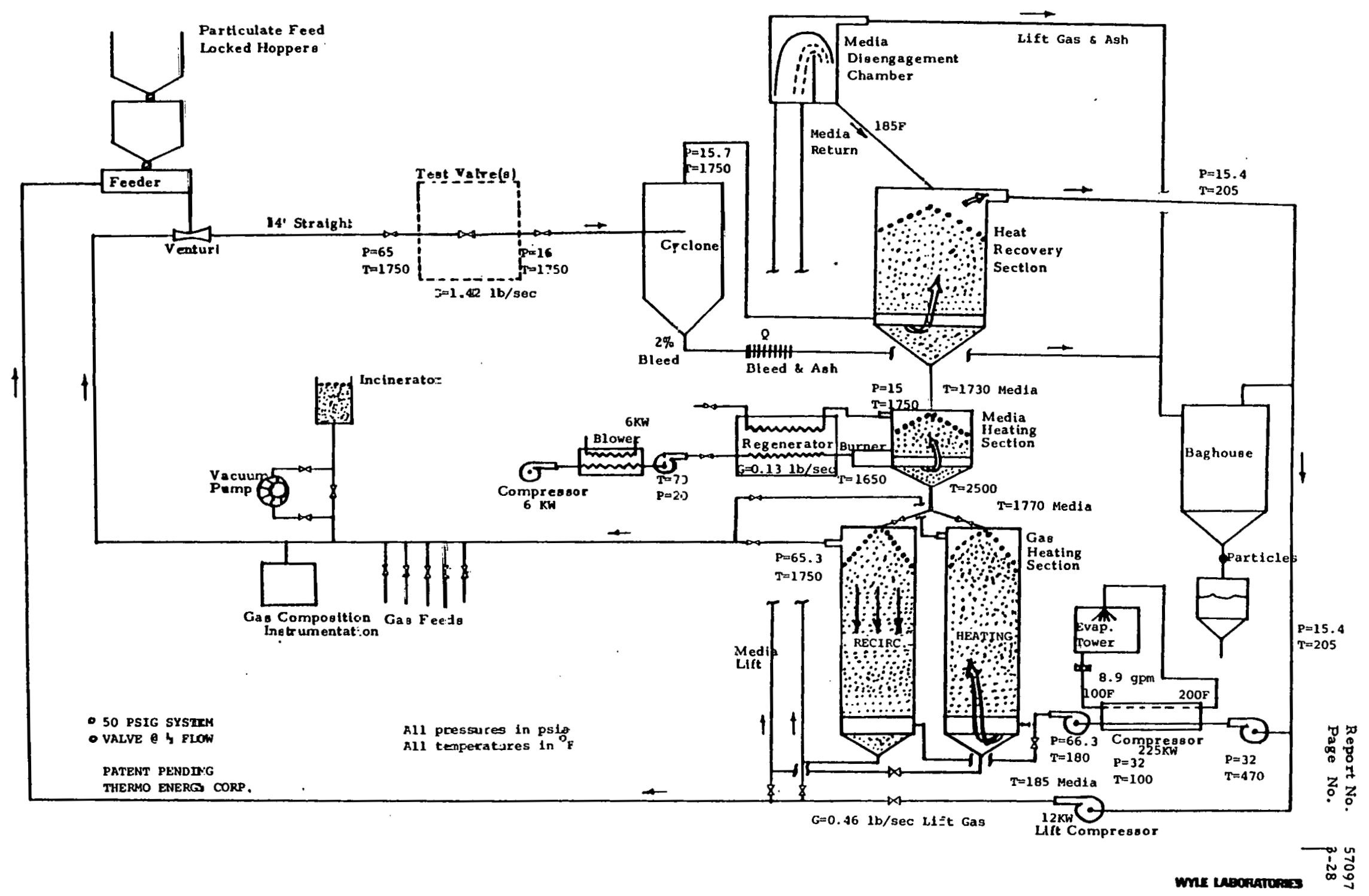


FIGRE 3-18 FLOW SCHEMATIC-RECIRCULATING MEDIA APPROACH

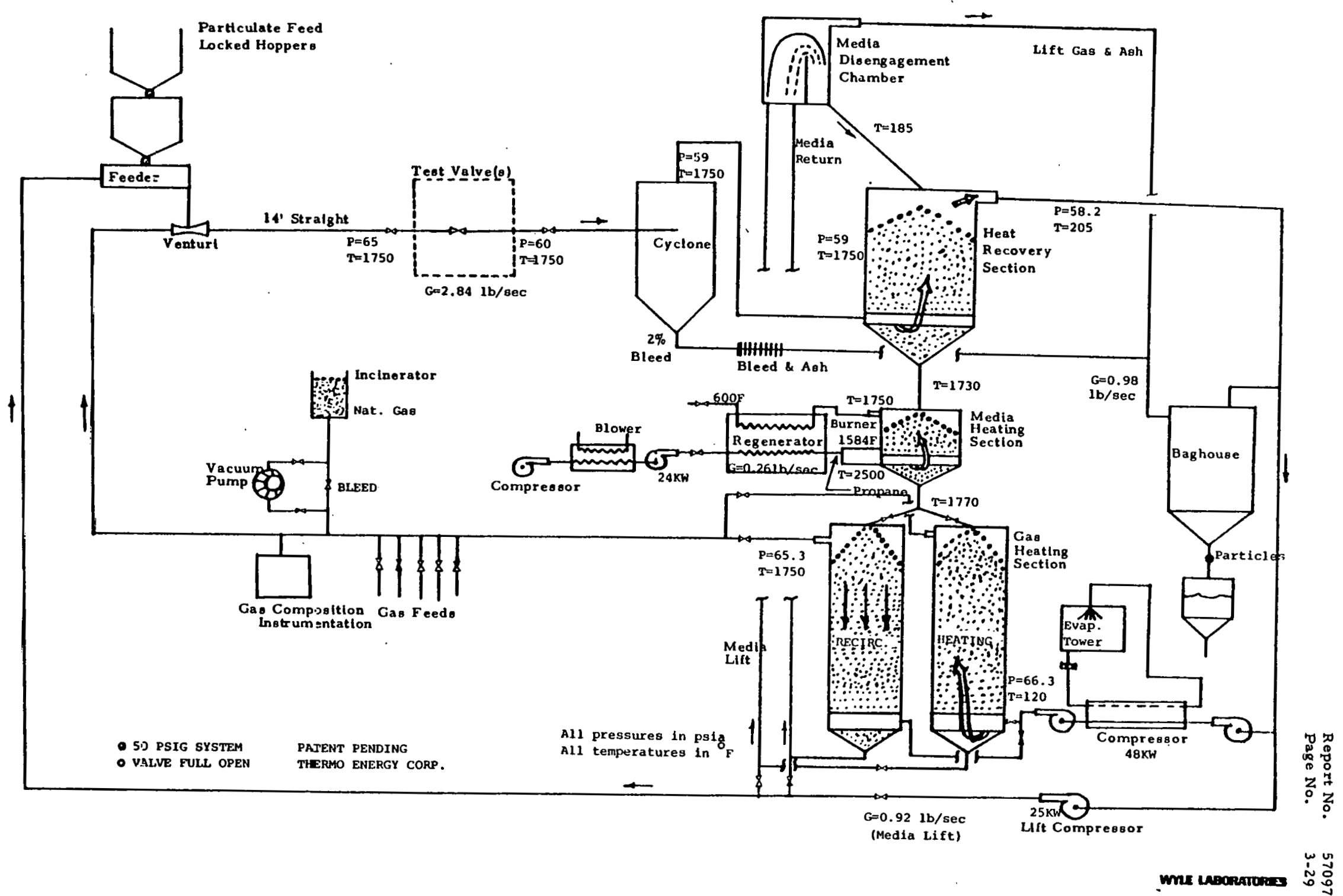


FIGIRE 3-19 FLOW SCHEMATIC-RECIRCULATING MEDIA APPROACH

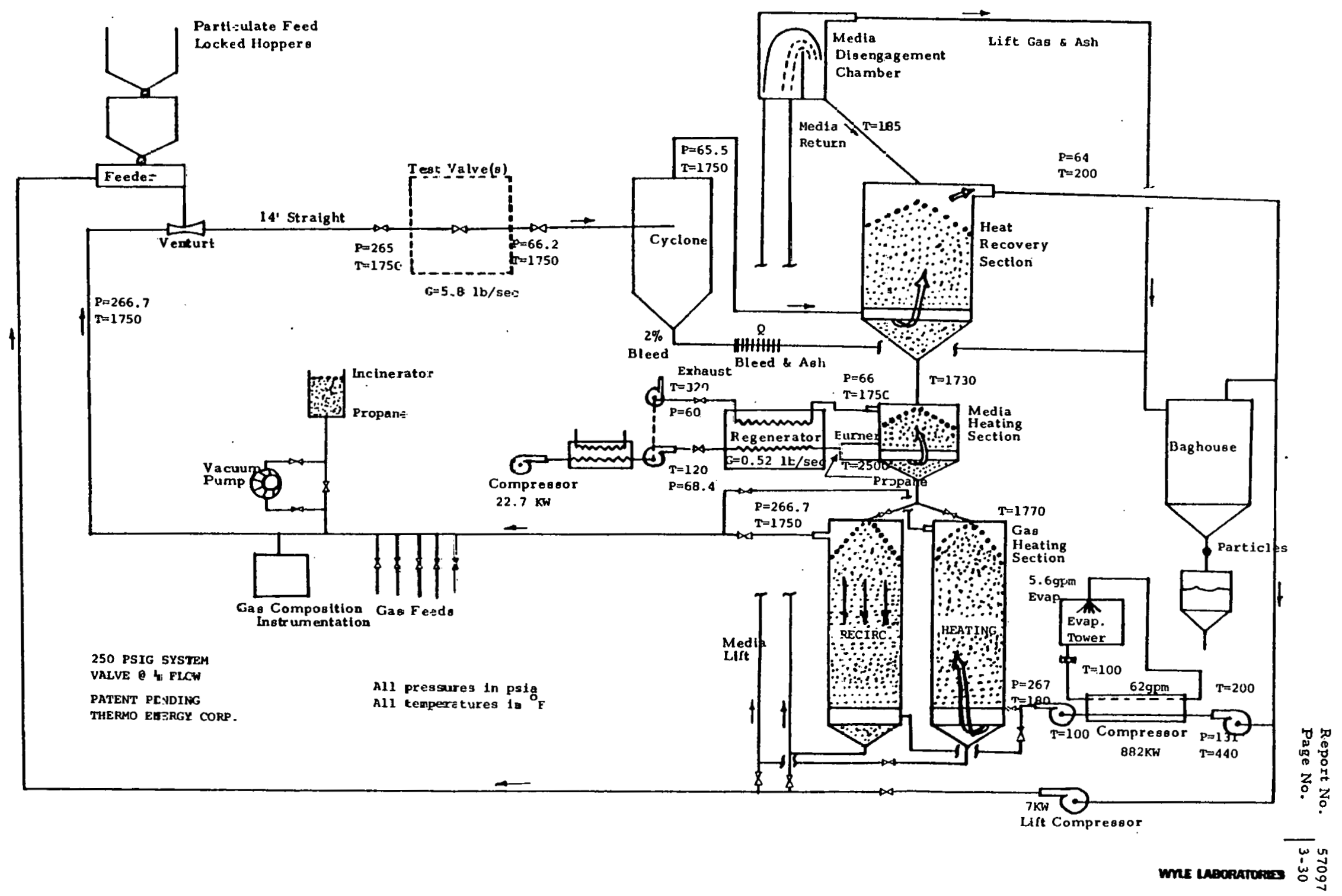


FIGUPE 3-20 FLOW SCHEMATIC-RECIRCULATING MEDIA APPROACH

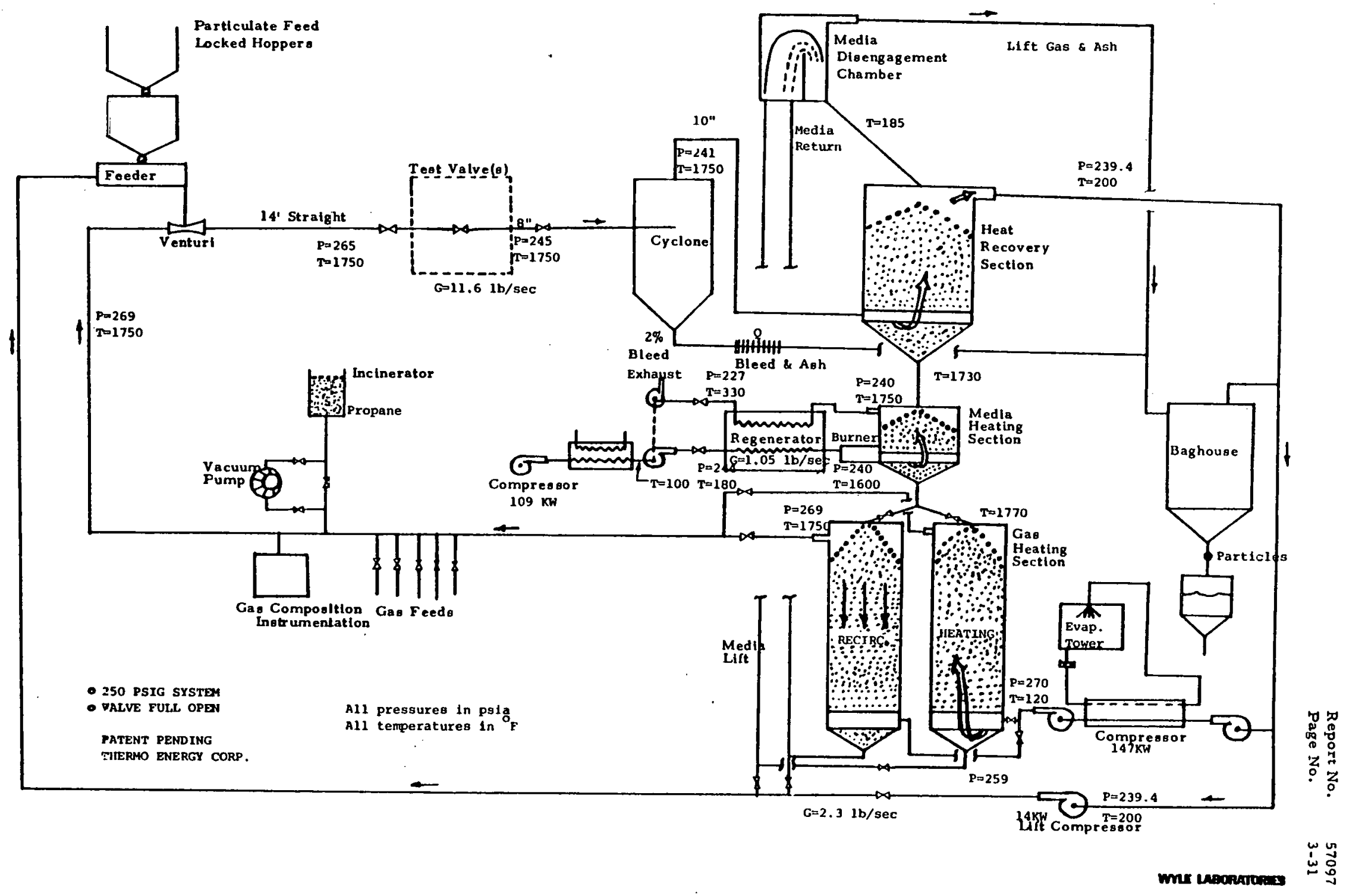


FIGURE 3-21

\section{RM-250 HEAT RECOVERY SECTION}

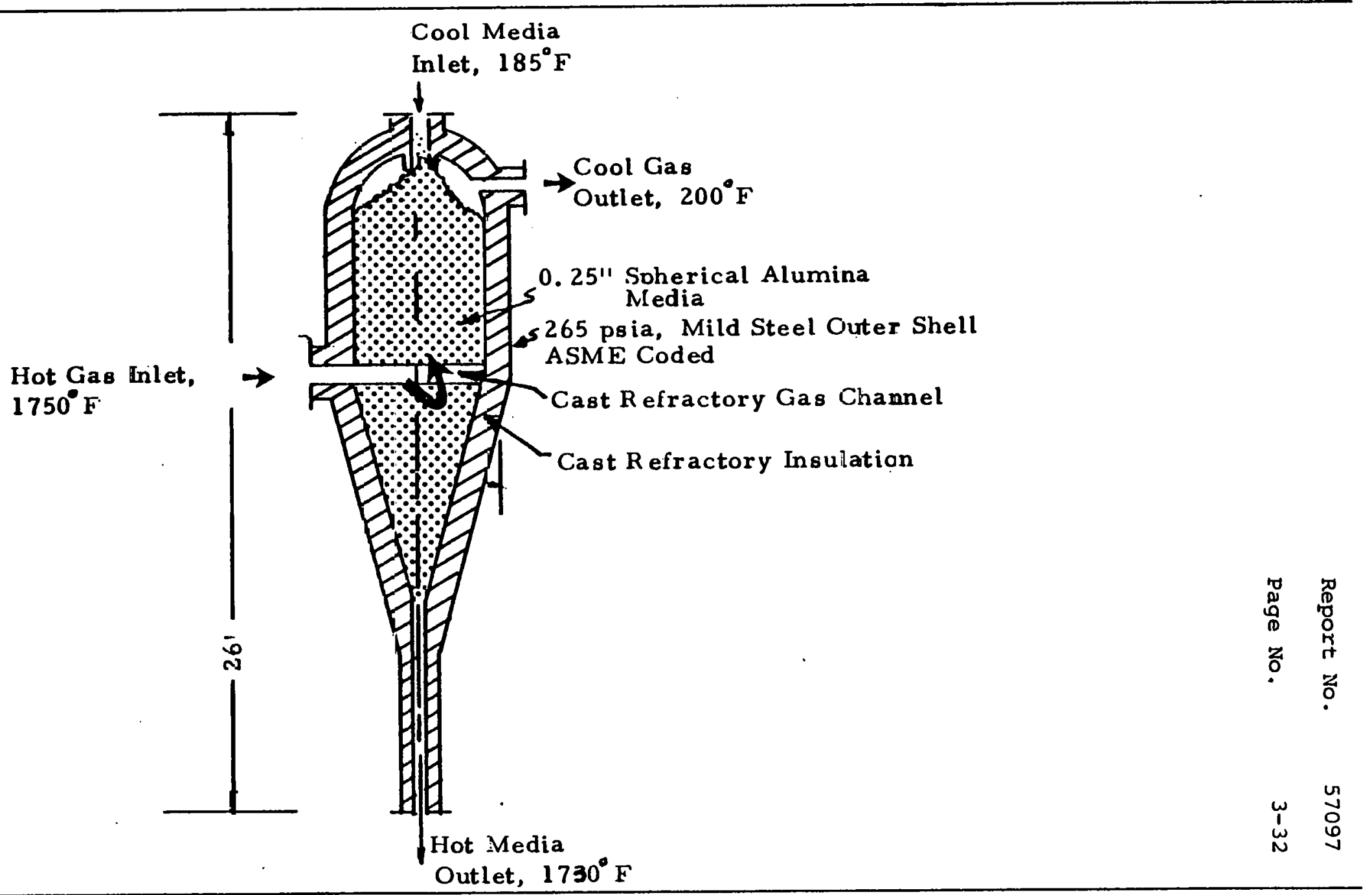


FIGURE 3-22

RM-250 MEDIA HEATING SECTION

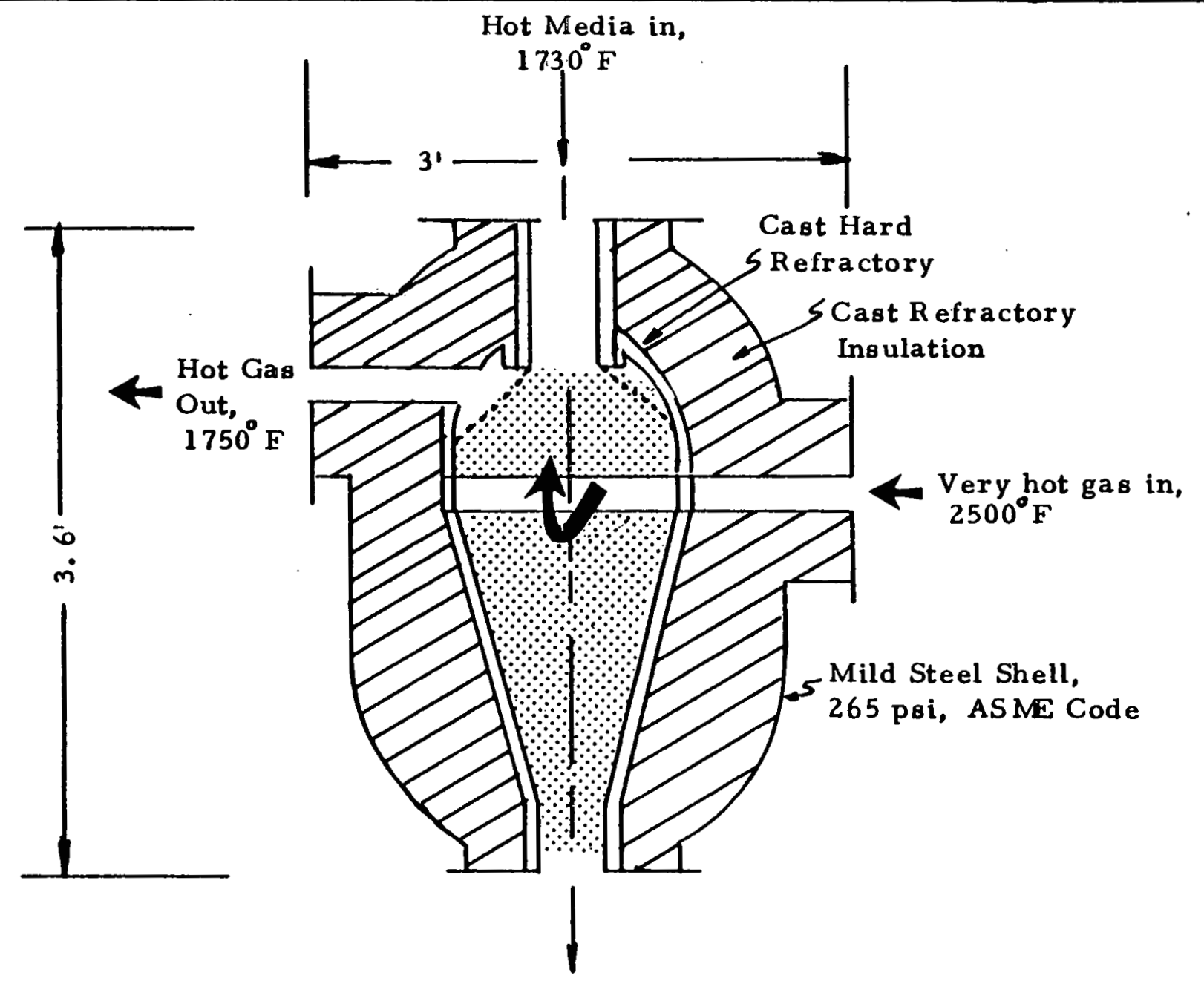


PAGE NO.

3.10.3 RM-250 Gas Heating Section

Figure 3-23 presents a sketch of one of two vessels of the gas heating section. This vessel received hot media until it is filled; after filling it is disconnected from the media flow system and heats the fuel gas to $1750 \mathrm{~F}$.

The vessel is manufactured from mild steel and contains a cast refractory lining of both insulating refractory and hard surtace refractory. Cool gas enters through refractory channels and passes through the media for heating. Each vessel contains 183,000 pounds of media.

3.10.4 RM-250 Baghouse

Figure 3-24 presents a sketch of the baghouse for the $R M-250$ system. In construction it is similar to the baghouse of the conventional design systems, but it is much smaller.

3.10.5 RM-250 Air-Poc Heat Exchanger

Figure 3-25 presents a sketch of the Air-Poc Heat Exchanger used to preheat the air for the burner which supplies heat to the media heating section. It is similar in construction to the air regenerator used on the conventional system but only a fraction of its size.

3.11

3.12

Overal1 size of $R M-250$ System

Figure 3-26 presents a sketch of the size of the major components of a RM-250 system.

Energy Summary Recirculating Media

Figure 3-27 presents the energy summary for the recirculating media systems. These energy summaries are calculated assuming the test valve is sycling between full open and half open throughout the test period. 
FIGURE 3-23

GAS HEATING SECTION, 2 REQ'D.

Hot Media Inlet

$1770^{\circ} \mathrm{F}$

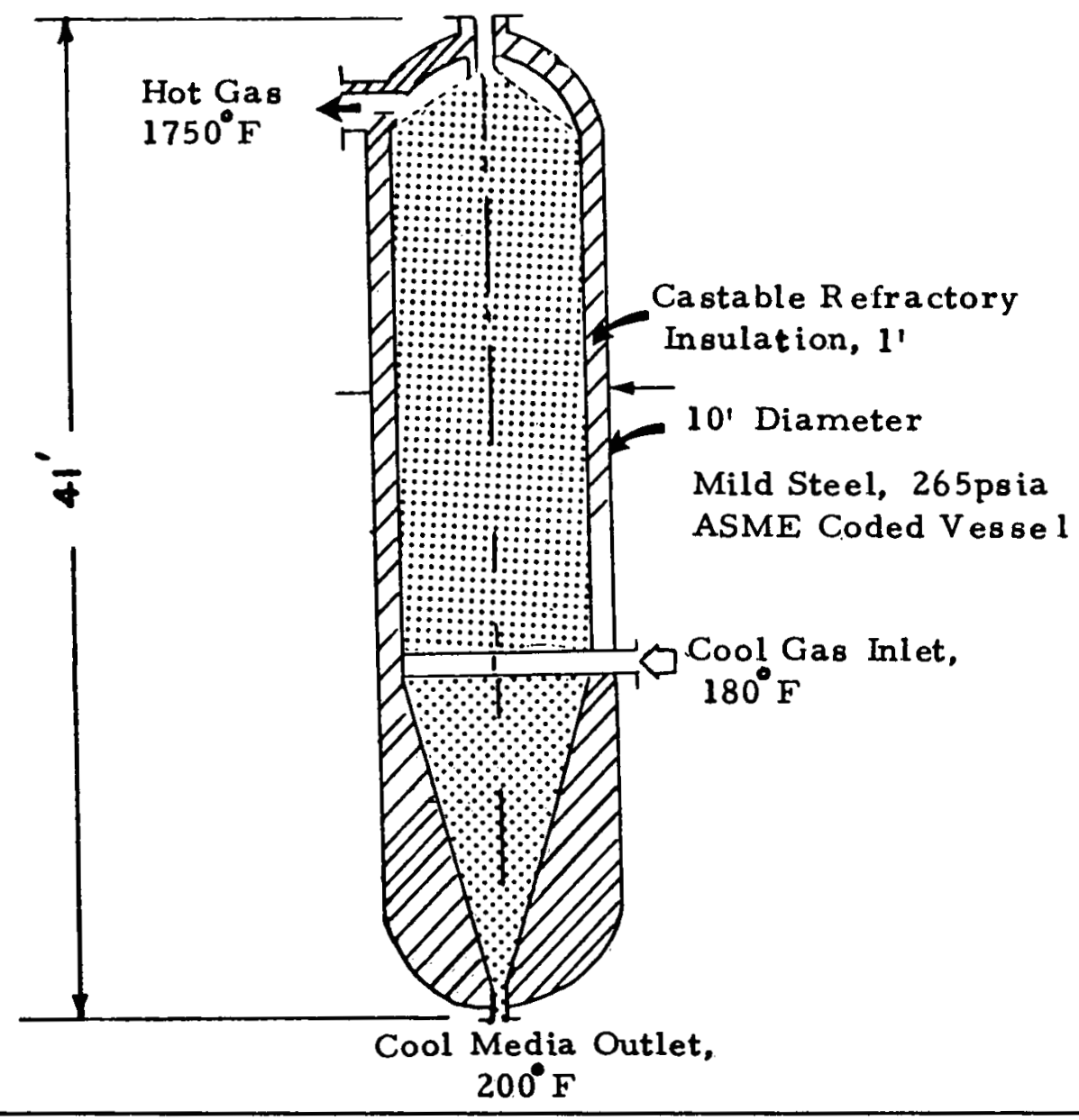


FIGURE 3-24

\section{RM-250 BAGHOUSE}

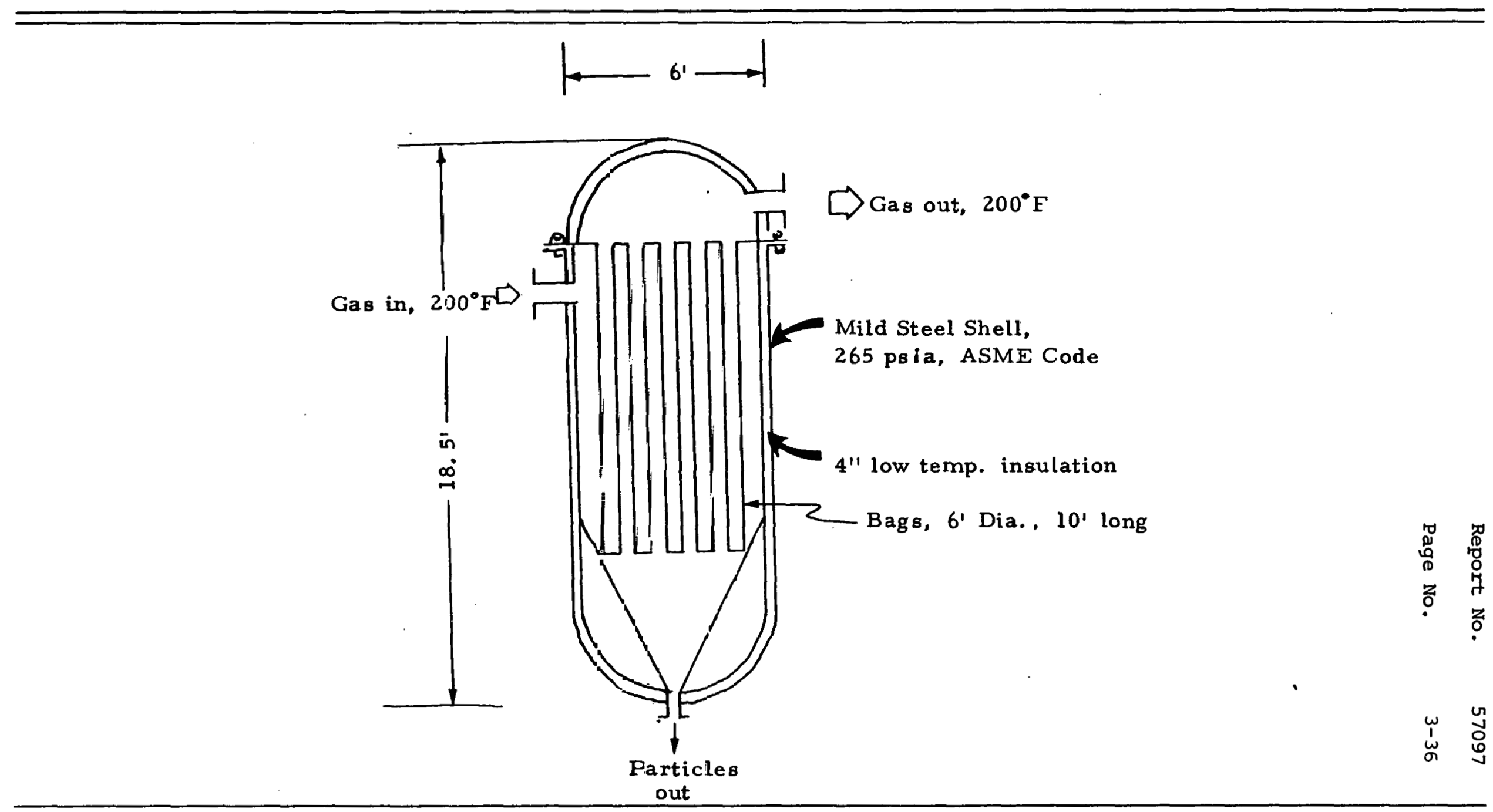


FIGURE 3-25

RM-250 AIR - POC HEAT EXCHANGER

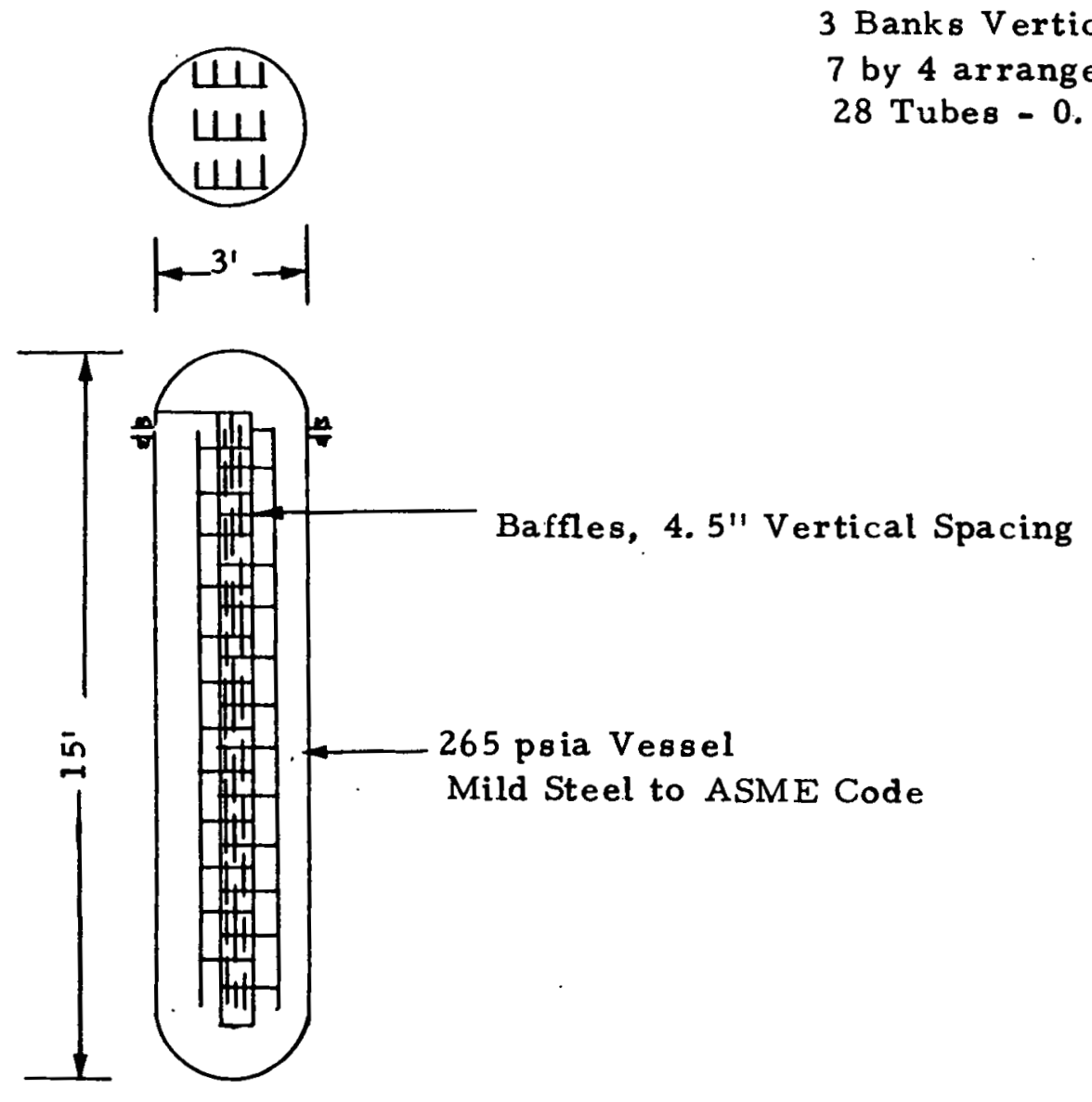


FIGURE 3-26

\section{RM-250 OUTLINE OF MAJOR COMPONENTS}

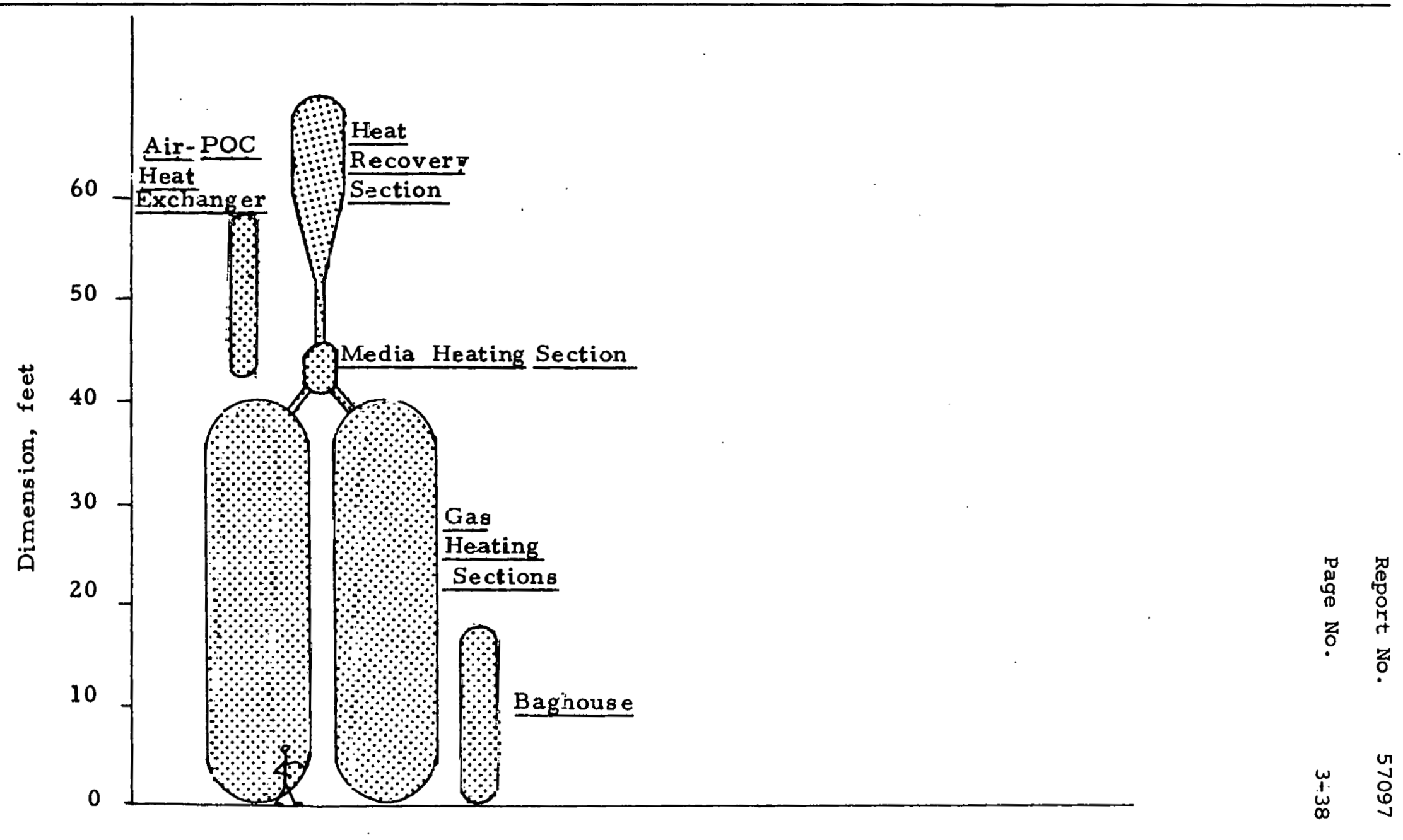




\section{ENERGY SUMMARY - RECIRCULATING MEDIA SYSTEMS}

\begin{tabular}{|c|c|c|c|c|}
\hline & & \multicolumn{2}{|c|}{\begin{tabular}{l|l} 
ENERGY CONSUMED IN 24 HOURS \\
RM - 50 & RM -250
\end{tabular}} & \\
\hline 1. & NATURAL GAS & $4 \times 10^{6} \mathrm{BTU}$ & $18 \times 10^{6} \mathrm{BTU}$ & \\
\hline 2. & CIRCULATING GAS COMPRESSOR & $1680 \mathrm{KWH}$ & $12,360 \mathrm{KWH}$ & \\
\hline 3. & AIR COMPRESSOR & $408 \mathrm{KWH}$ & $1,584 \mathrm{KWH}$ & \\
\hline 4. & LIFT GAS COMPRESSOR & $432 \mathrm{KWH}$ & $252 \mathrm{KWH}$ & \\
\hline & TOTAL: IN NATURAL GAS EQUIVALENTS & $30 \times 10^{6}$ BTU & $163 \times 10^{6}$ BTU & $\begin{array}{l}\text { T⿱艹 } \\
0 \\
0 \\
0 \\
0\end{array}$ \\
\hline
\end{tabular}

- Based on second law 
PAGE NO

$3-40$

3.12

(continued)

Comparing these results with the energy consumption for the conventional design system, the RM-250 uses only seven per cent of the propane of the $C D-250$. On an overall energy basis, it uses only 36 per cent of the energy of the CD-250.

Comparison of Energy Consumption

F'igure 3-28 presents a bar graph showing the relative energy consumption between the systems studies. The solid bars represent the total energy over the fence, be it propane gas or electric power. The dashed lines represent the overall propane gas or oll equivalent which is obtained by converting electric power to a gas or oil equivalent. As seen from the figure, the RM-50 and the RM-250 use about one-third of the overall energy of their conventional counterparts.

\section{Comparison of Capital Costs}

Figure 3-29 presents a bar chart showing the relative capital costs of the four systems studied. The cost of the conventional design systems is higher principally because of the cost of the heat transfer equipment. The $C D-50$ and $C D-250$ both need pebble bed heaters in addition to the metal tube regenerator to reach the 1750 F gas temperature required in the system. The large cost Increase of the CD-250 over the $C D-50$ is because the heat transfer increases proportionally with the pressure.

\section{Comparison of Operating Costs}

Figure 3-30 presents a comparison of operating costs for the four systems. The major costs are test manpower and electrical power. The difference between the $C D$ designs and the RM designs is due to the fuel savings with the RM systems.

Comparison of Capital Plus Five-Year Operating Costs

Figure 3-31 presents a bar chart showing the sum of the capital cost plus five years of operating cost for the four systems studied (all in 1980 dollars). As shown in the figure, the total cost for the RM-250 is approximately equal to the CD-50. 
FIGURE 3-28

\section{RELATIVE ENERGY CONSUMPTION}

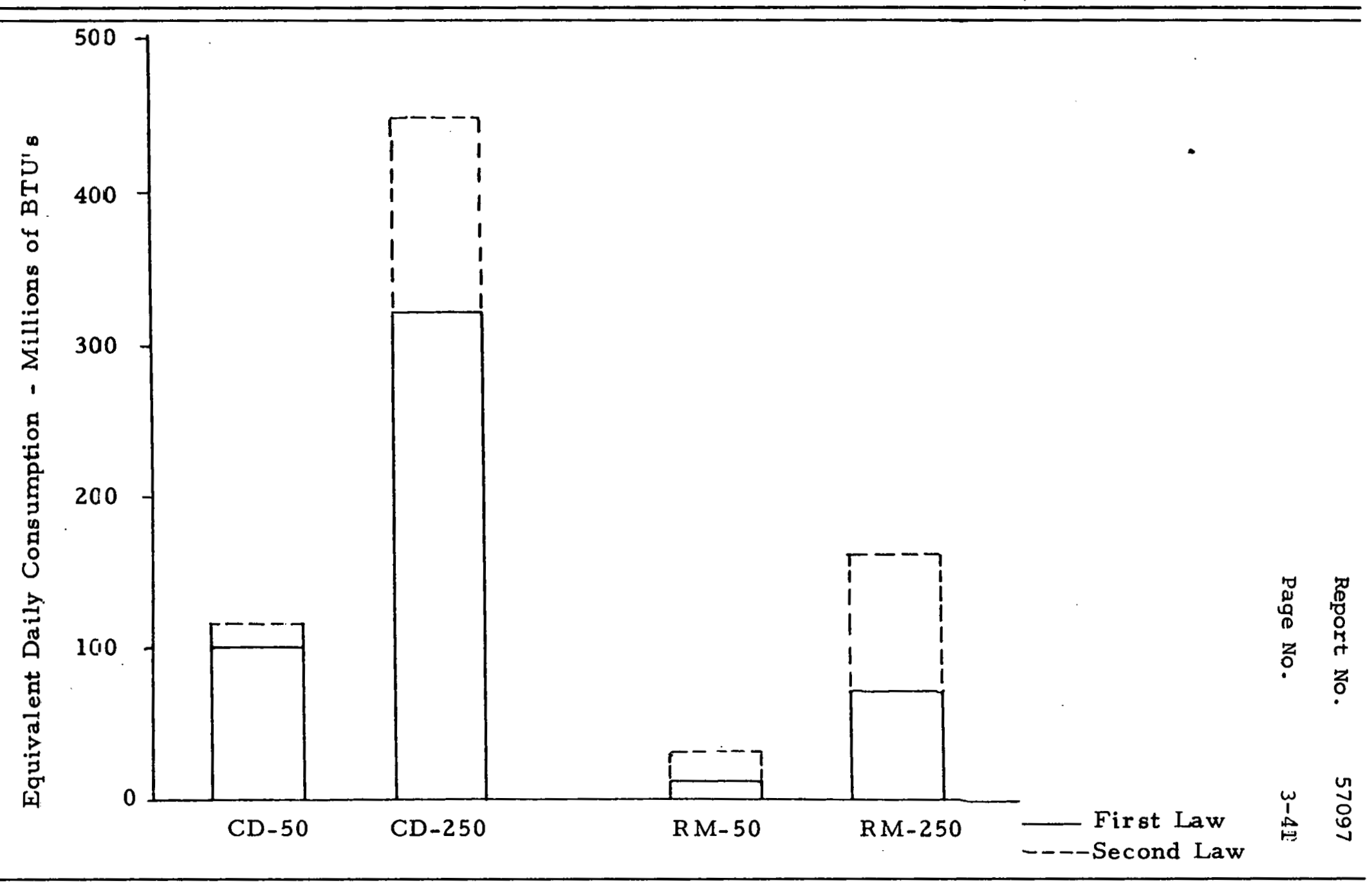


FIGURE 3-29

CAPITAL COST

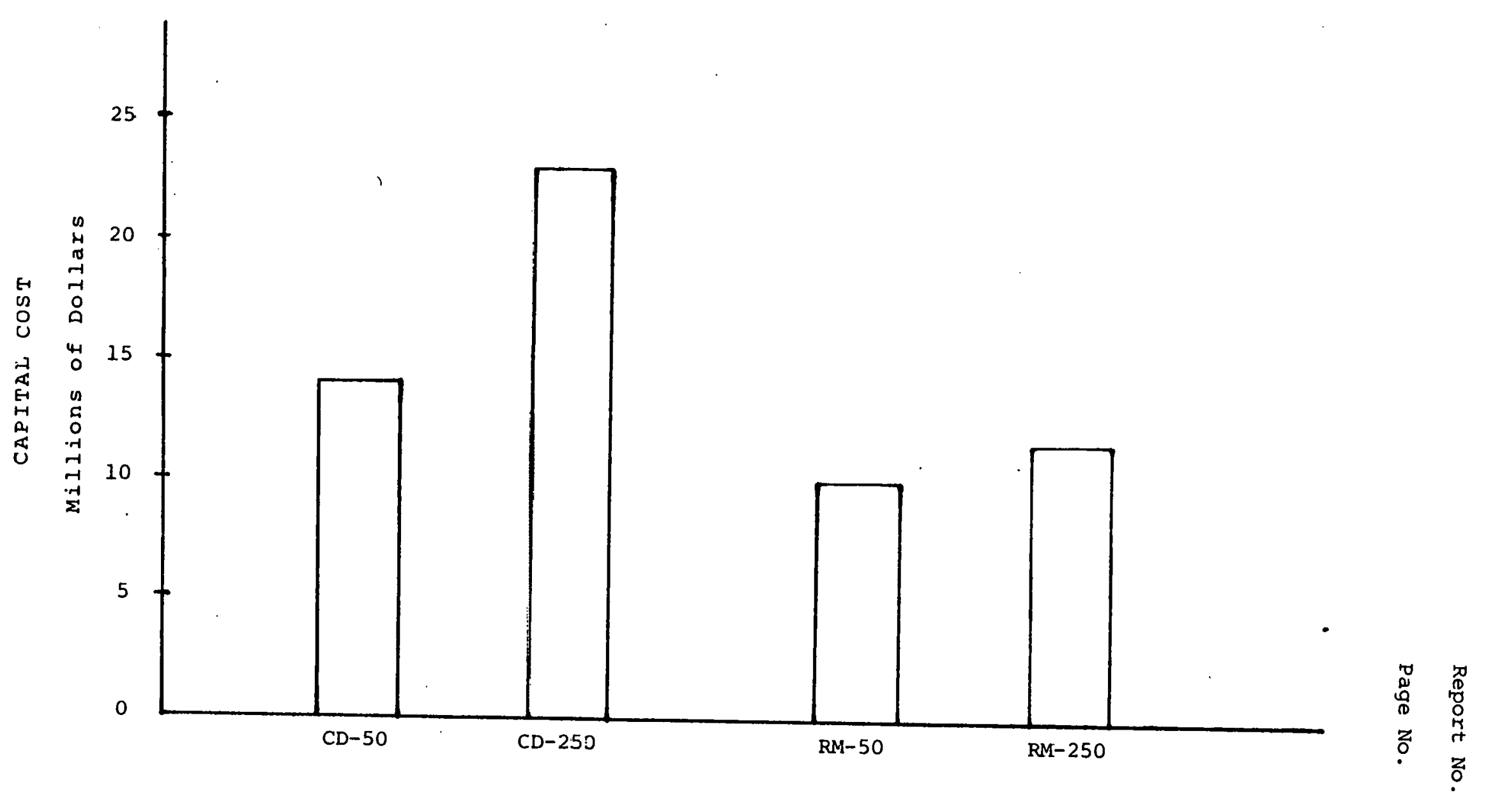

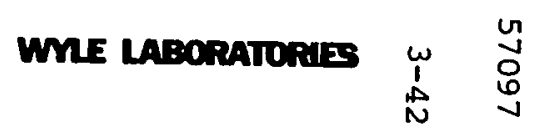


FIGURE 3-30

OPEPATING COST PER TEST HOUR

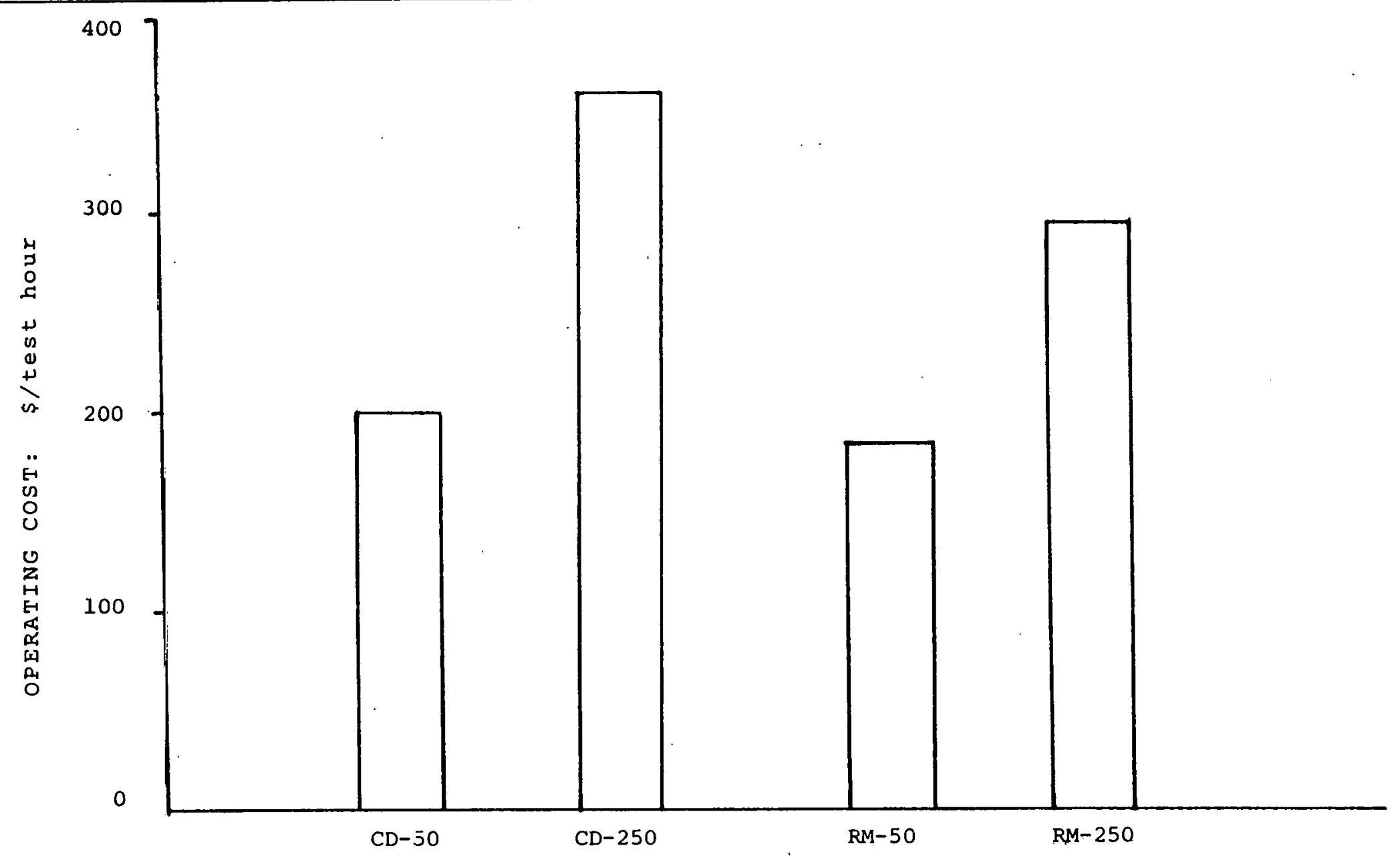


FIGURE 3-31

CAPITAL COST PLUS FIVE-YEAR OPERATING COSTS

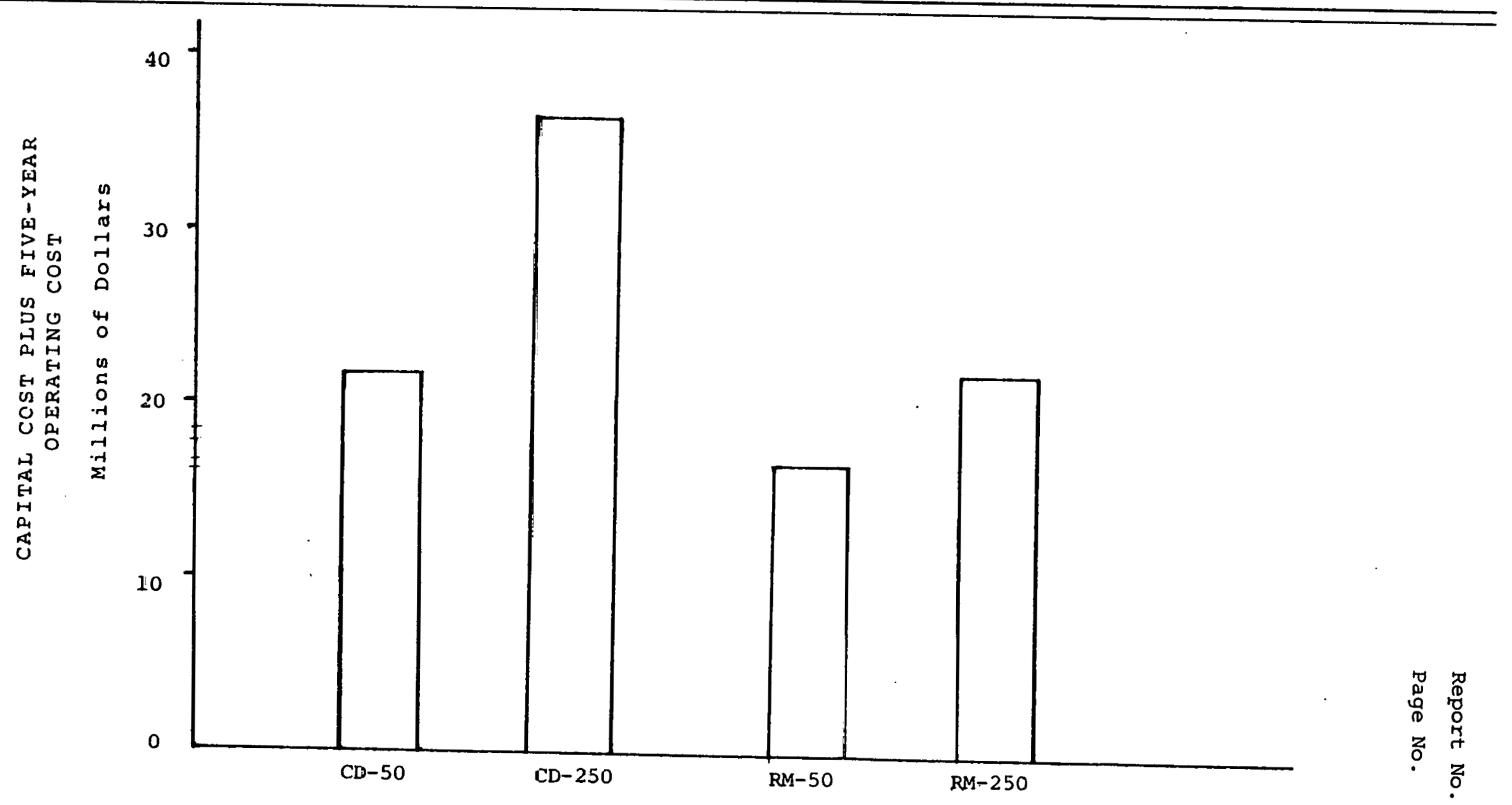

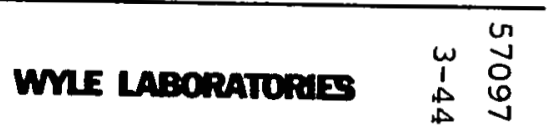


The design studies and costing studies have indicated that :the recirculating media system is cheaper to build and operate than a conventional design system of equivalent performance. Further, the technology of the Recirculating Media Systems is not exotic; many elements of it have been proven in Morgantown Energy Research Programs on hot gas clean-up.

Based upon the energy savings and the cost savings, the recirculation media system was selected for further study in the program. Further, since the 250 psig system cost little more than the 50 psig system, and offered many benefits, it was selected over the 50 psig system. It is interesting to note that on a five-year basis the $R M-250$ cost no more than the CD-50. 
The hot dirty gas valve must experience the particularly harsh environment of a gas flow composed of carbon monoxide, carbon dioxide, water vapor, methane, hydrogen, and other fuel gases combined with solid particulate matter derived from the ash of the coal. Not only does the particulate contain inert materials such as aluminum oxide and silicon dioxide which are strongly abrasive, but in addition it contains sodium sulfate, potassium sulfate, sodium chloride, and other alkali metals which are extremely corrosive at 1600F, the temperature region at which the valve must operate. The corrosive effect of these materials is well known from experience with turbine blades. At a temperature range of $1550 F$ to $1750 F$, the particulate can be semi-liquid or soft and extremely adhesive. This particulate can also melt and form a glassy surface across the metal surfaces of the test valve causing a corrosive condition.

Normally, metals such as chromium or nickel when exposed to elevated temperatures will form an oxide layer which offers protection from corrosion such as experienced within an aircraft jet engine. In the case of the hot dirty gas valve, this oxide layer protection is not available since the gas stream is highly reducing with essentially no oxygen present in the flow to provide a protective oxide layer over the metal. Additionally, as the valve attempts to throttle the dirty gas flow, high pressure differentials will occur across the valve seat with the gas velocity attaining several thousand feet per second. Particulates carried at this velocity tend to scour the valve surface clean and abrasively erode the metal surface. Concurrently, since the metal is continuously scoured clean, the virgin material is constantly exposed and does not have the opportunity of being protected by a layer of intermediate corrosion products as would be the case in the superheater tubes of a coal-fired boilex. 
The internal surfaces of the test facility must withstand the same harsh environment of the test valve and must do so for 8000 hours a year with high reliability. From the preceding discussion it is clear that metals would not survive and hence, all of the internal surfaces which contact the fuel gas when it is hot are constructed from refractory material. Many commercial refractories will not cuslude ill lle presente if ival asli in a reducing atmosphere of $1750 F$.

\subsection{System Schematic}

Figure 4-1 presents the system schematic for the RM-250 system. It is essentially the same as the $R M-250$ schematic presented in Section 3, except that it has the pressure and temperature instrumentation locations superimposed upon it. The overall operation of the system is as described in section 3.

General Arrangement of the Test Facility

Figure 4-2 presents a plan view of the equipment and general piping layout of the facility. Figure 4-3 presents the west elevation as seen from the section line in Figure 4-2. Figures 4-4 and 4-5 together present the east elevation as seen from the section line. Figuces 4-2, 4-3, 4-4, and 4-5 are also supplied as drawing in addition to their inclusion in this report.

As seen from the figures, the particulate feed subsystem, the valve test cell, and the cyclone are all located at ground level on the north side of the 50' $x 50^{\prime}$ concrete pad. The hot dirty gas leaving the cyclone is piped approximately 80 feet vertically upward to the heat recovery section of the heat exchanger. The cooled gas leaving the heat recovery section is piped 80 feet vertically downward to the main compressor which is mounted on the south side of the concrete pad.

The heat recovery section is mounted in an elevated position to allow the flow of hot media (by gravity) from the heat recovery section through the media heating section and into the gas heating section. 


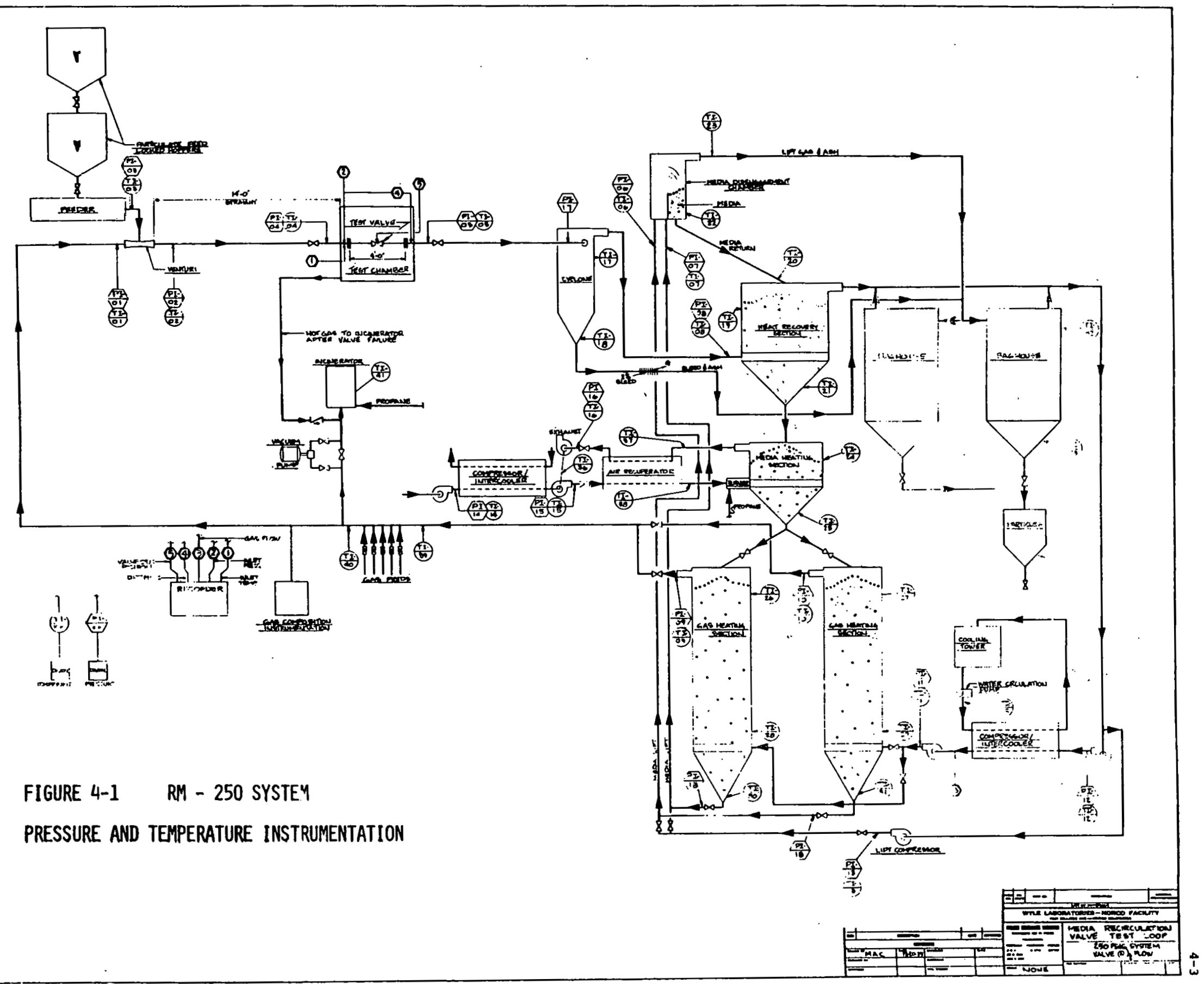


FIGURE 4-2 - PLAN VIEN DF TEST FACILITY EQUIPMENT AND GENERAL PIPING

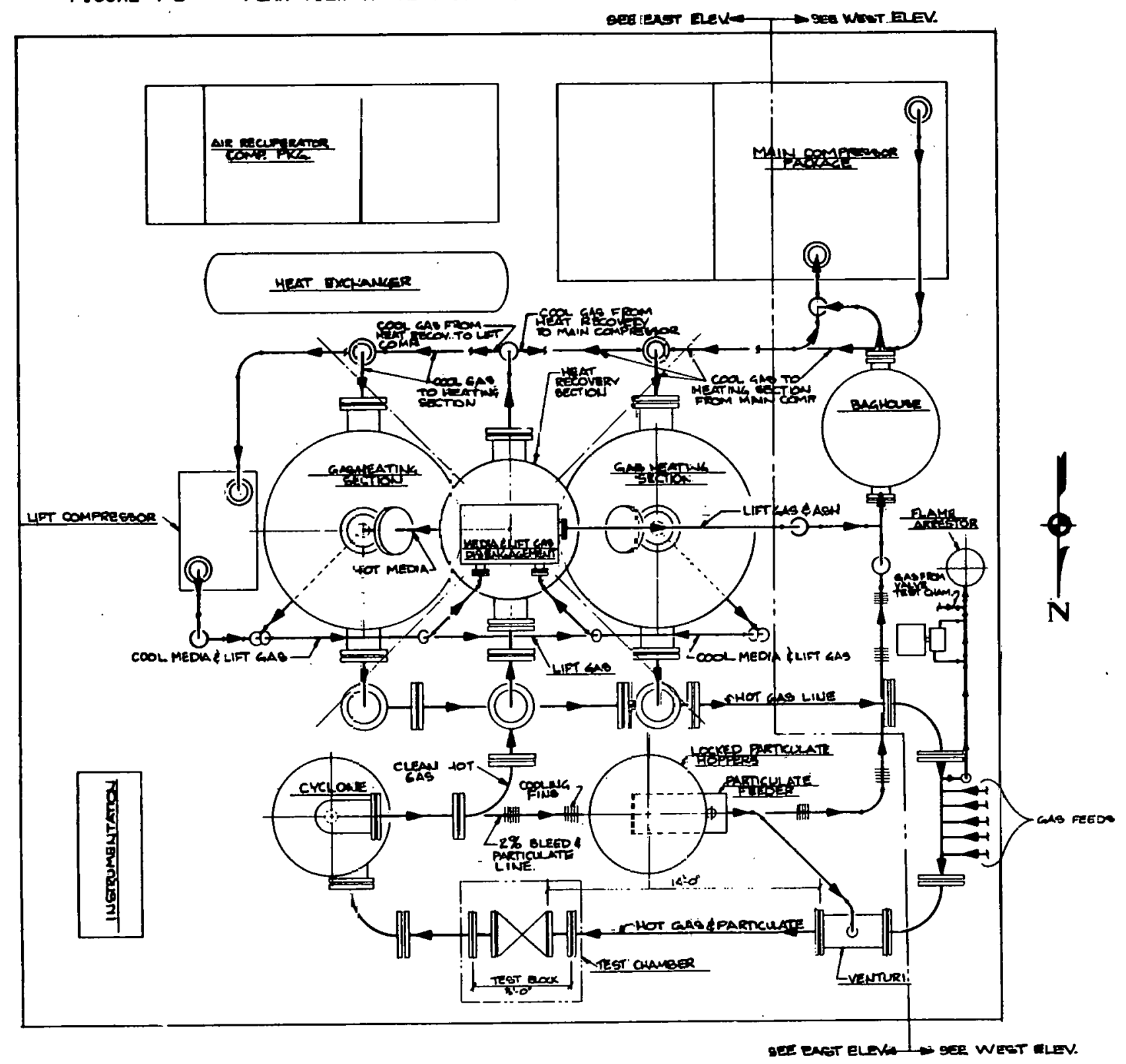

Report No.

57097

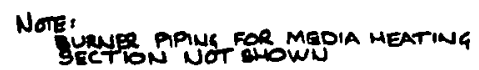

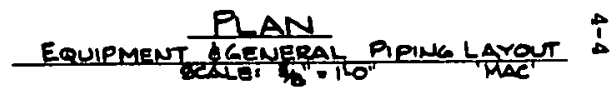
$250-L-\infty O$ 


\section{FIGURE 4-3 - EAST ELEVATION OF TEST FACILITY}

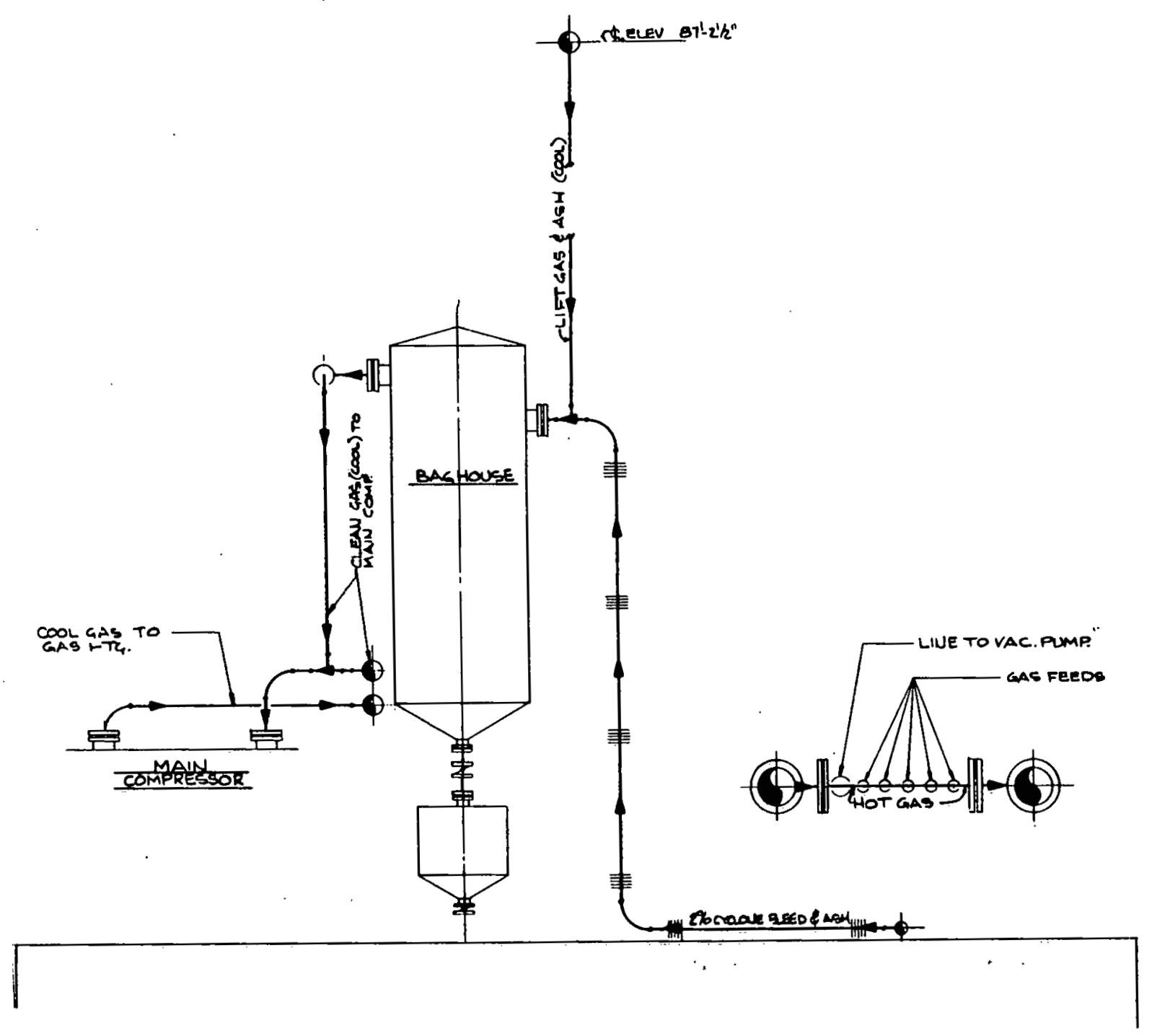

ELEV LOOKING WEST 'MAC'

$250-L-\infty 02$ 
FIGURE 4-4 - MEST (LOMER) ELEVATION OF TEST FACILITY

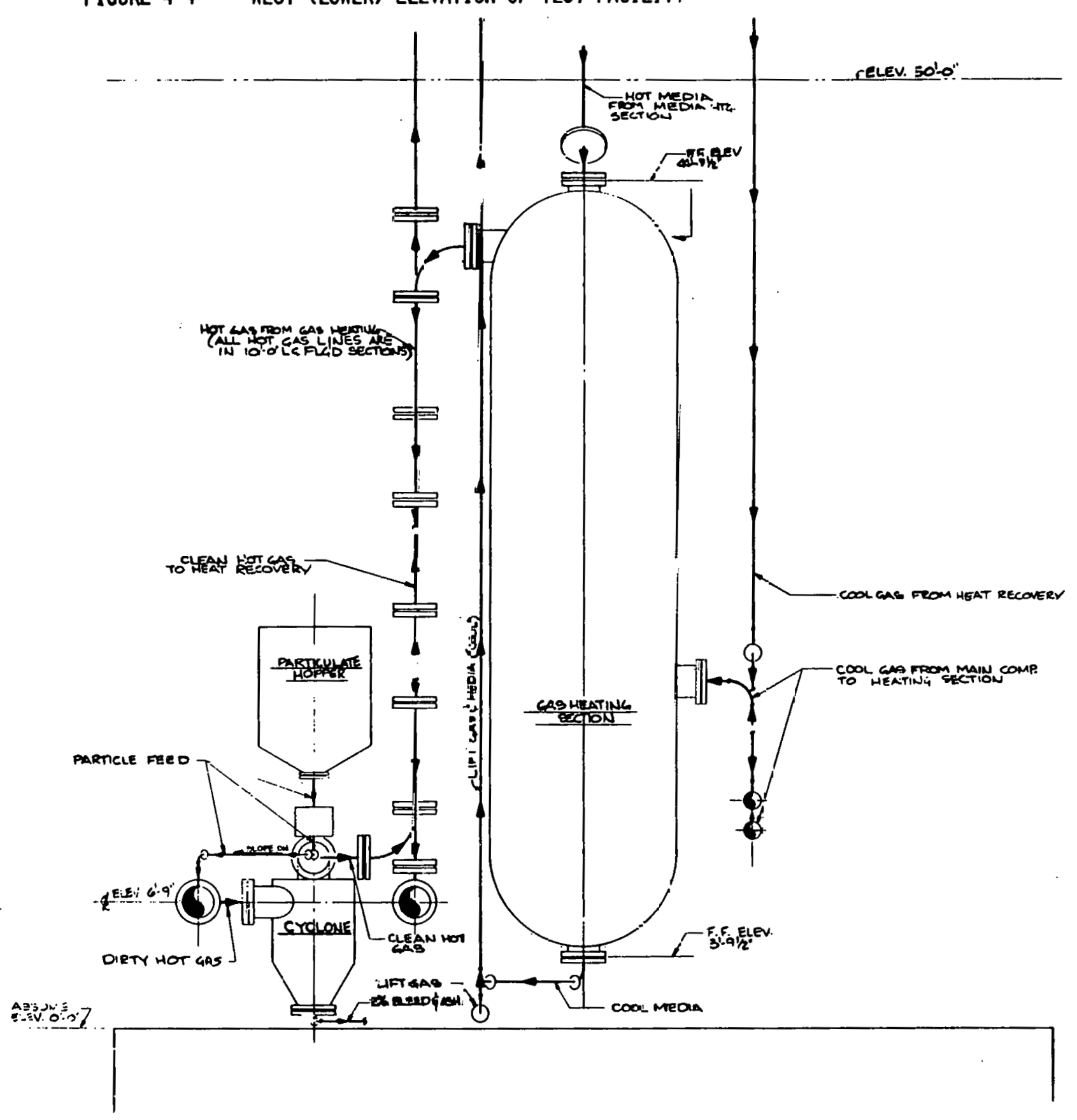

$250-L-003$ 


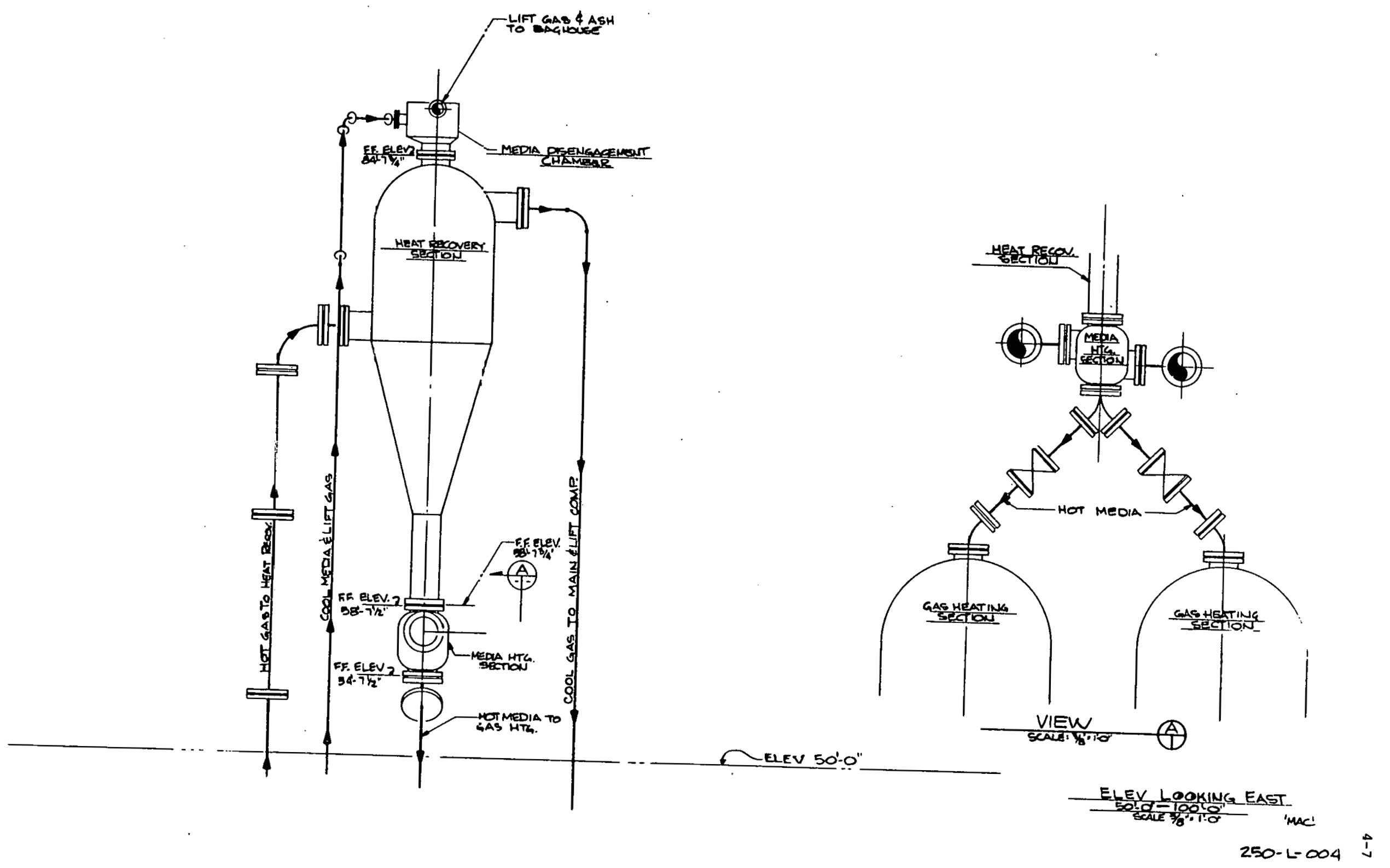


PAGE NO

$4-8$

4.4 (continued)

As shown in the figures, the media heating section is mounted directly below the downcomer of the heat recovery section. Below the media heating section the downcomer splits to feed media into edcll of the two vessels of the gas heating spstion. A hot media shut-off valve is included in each of the downcomers.

Cooled media is recovered from the bottom of each of the vessels of the gas heating section and lifted 85 feet into the air to the media disengagement chamber at the top of the media heating section. The media falls into the heat recovery section and the spent lift gas with its particulate load is ducted vertically downward to the baghouse located on the west side of the concrete pad.

The air compressor is located on the south side of the pad adjacent to the main compressor. It supplies compressed air to the air heat exchanger similarly located on the pad. Heated air from the heat exchanger is piped vertically upward to the propane burner which is mounted adjacent to the media heating section. (The burner is not shown in the figures.) Hot gas leaving the media heating section is piped vertically downward to the air heat exchanger.

The concrete pad used to support the vessels and piping is $50^{\prime} \mathbf{x}$ 50' $x$ 5' thick. The atcel cupport structure tor the vessels is inbedded in the conerete par, Expansion joints are used in the lines between vessels to allow for expansion of the components during heat-up. Guy wires attached to dead men are used to brace the structure for horizontal earthquake loads, which are $1 / 3 \times$ gravity.

4.5 Gas Storage and Feed Subsystem

The closed circuit test loop contains 1800 cubic feet of free volume. and will hold 361 pounds of fuel gas mixture at a pressure of 250 peia and an average temperature of 1500F. For the gas composition specified in the METC specification, the quantities of gas would be as follows: 
PAGE NO

$4-9$

$4.5 \quad$ (continued)

$\begin{array}{lr}\text { Gas } & \text { Weight (lbs) } \\ \mathrm{N}_{2} & 3.6 \\ \mathrm{H}_{2} \mathrm{~S} & 4.3 \\ \mathrm{H}_{2} & 18.8 \\ \mathrm{H}_{2} \mathrm{O} & 61.0 \\ \mathrm{CO} & 151.3 \\ \mathrm{CO}_{2} & 118.8 \\ \mathrm{CH}_{4} & 3.0\end{array}$

The gases would be supplied in individual containers and charged into the test loop individually through 250 psia pressure regulators. Nitrogen, oxygen, and hydrogen are available at the site. Water vapor would be supplied by a small steam generator. The remaining gases would be purchased in compressed gas cylinders.

Prior to charging the system with fuel gas, air is evacuated from the system down to $1 / 4$ psia by the vacuum pump (shown in Figure 4-1). A mass spectrometer with data processing capability provides a real time readout of the composition of the gas mixture in the test loop. The mass spectrometer can be used to assist the operator in arriving at the desired composition while filling the system.

During operation, the gas composition will change slightly due to leakage of fuel gas from the system, leaking of propane products of combustion into the system, and chemical vaporization of elements of the coal ash. By monitoring the gas composition with the mass spectrometer, the operator can add gas components to adjust the gas mixture while the test loop is in operation.

The gases are stored in cylinders attached to supply manifolds on a small pad near the test facility. Because the quantities of gas used in the facility are small the storage area is likewise small.

Particle storage and Feed Subsystem

4.6.1 Type of Particulate Used in the System

The hot dirty gas valve test facility is designed to use any dry finely-ground solid as particulate for the valve testing. Different test environments may be selected by the choice of particulate. 
PAGE NO

$4-10$

\subsection{1 (continued)}

If a purely abrasive environment is desired a pure aluminum oxide particulate could be used. This material can be purchased in specified sizes and a mixture made up to match the particle size distribution in the Morgantown specifications. Aluminum oxide does not melt until $4500 F$ is reached and will not react with the gas constituents of the fuel gas at. $175 \mathrm{nF}$. Henre, it may be roused in tho system unt1l its size deviates markedly from its original size due to attrition.

More accurate simulation of the actual environment seen by a hot gas valve is obtained by using coal ash. Here the corrosive and plugging aspects of the environment are simulated as well. However,in passing through the system the physical and chemical properties of the ash will be substantially changed at the elevated temperatures. Hence, for coal ash testing a once-through passage of the coal ash is recommended. Since the system uses 6000 pounds of ash per day, grinding actual coal ash to a rigid size specification would be expensive. Hence, the use of fly ash from a pulyerized coal boiler is recommended for most valve testing. Pulverized coah ash from a utility boiler is predominately four to eight microns in diameter while the size of particulate specified by METC is predominately one to ten microns in diameter. The size range of the fly ash is close enough to that specified in the METC specifications to provide essentially similar results in the valve test loop.

\subsubsection{Ash Transportation, Receiving, and Storage}

Fly ash from a pulverized cual utility boller will be transported to the test site by enclosed trucks and deposited in a silo ten feet In diameter and 24 feet high. The silo will hold approximately 100 tons of fly ash, enough for 35 days of testing. Fly ash is pneumatically transported from the silo to the locked hoppers of the particle feeder. 
PAGE NO 4- -11

4.6.3 Particle Feeder

A calibrated screw type feeder will be used to meter and to feed the particulate from the pressurized locked hopper into the main gas stream. The maximum particle flow rate is four pounds per minute. A stock feeder with an explosion-proof motor is mounted in a pressurized housing pressurized by cool fuel gas at a pressure slightly above the system pressure in the main gas stream pipe at the location of the feeder. Thus a small positive flow of fuel gas will be established from the housing into the main pipe through the particle transport pipe. Particulate exiting from the feeder is entrained in this gas stream and carried into the mainstream.

All measurement of particle feed rates is accomplished by measuring the speed at which the feeder operates and calculating the flow rate from the calibration curve.

4.6.4 Particle Dispersion

The particle transfer pipe from the feeder exit terminates at the throat of a venturi placed in the hot fuel gas mainstream. The eight-inch diameter pipe narrows to 4.8 inches at the throat of the venturi; the divergent section of the venturi has a wall divergence angle of 16 degrees, causing mild turbulence in the flow but precluding breakaway of the flow. The particulate enters the mainstream at the throat. It is dispersed and uniformly distributed by the turbulent flow in the divergent section of the venturi. At full flow conditions there is a four psi pressure drop through the venturi.

Between the venturi and the valve test section a 14-foot straight section of pipe $1 \mathrm{~s}$ provided to allow the small particulate to be heated by the gas stream and by radiation from the walls of the pipe. Turbulence in the divergent section of the venturi will also contribute to particle heating. The absence of bends in the pipe upstream of the valve test section assures a uniform distribution of particulate at the valve face and the absence of any accumulation of particulate in the pipe upstream of the valve. 
PAGE NO $4-12$

4.7 Hot Gas Piping

As indicated in Section 3 earlier, the refractory of the hot gas piping is lined to preclude corrosion as would occur with a high temperature metal pipe. The pressure forces are reacted by a $22-$ inch schedule $80 \mathrm{mild}$ steel pipe. Inside this pipe cast-in-place refractory insulation is used to isolate the mild steel from the hot gas. A two-inch cast-in-place hard retractory face is cast over the insulating refractory to protert it from the abrasion and corrosion of the hot dirty gas moving at 175 feet per second. Anchors from the mild steel wall hold the cast refractory in place.

Because of the difficulty of casting the refractory into the pipe, the length of each section of hot pipe is limited to ten feet. Adjoining sections will be held together with 300-pound slip flanges. At each joint a space is provided between refractory sections for expansion of the refractory. This space is packed with a fiber type high-temperature insulation to preclude hot gas penetrating to the mild steel. Short sections of pipe are a convenience for repair of a local insulation failure.

Because the wear rate of the refractory liner is currently an unknown, it was assumed in the costing that a redundant set of hot gas piping was manufactured and that a complete changeout was accomplished after the first year of operation ( 8000 hours). After changeout the refractory on the used pipe was repaired and held ready for the succeeding changout.

Three six-inch burst discs are provided to avoid over pressurizing the toot loop.

4.8 Test Cell Subsystem

4.8.1 Design Philosophy

Design of the test cell for the hot dirty gas valves (eight-inch internal diameter) assumed that catastrophic valve failure would occur frequently enough that it was necessary to isolate the test valve from the surrounding environment, both for the safety of personnel, and to prevent the loss of fuel gas from the closed loop test system. 
4.8.2 Test Cell Enclosure

The test valve is enclosed in an ASME coded pressure vessel ten feet long, seven feet in diameter, and with a five-foot diameter head for valve removal and replacement. The vessel is lined with high temperature insulation. In the event of a catastrophic valve failure during testing, the hot gas will only fill the chamber and not escape into the atmosphere. Instrumentation in the chamber will warn the operator of this condition with an annunciator.

As an additional feature, the test valve enclosure may be used to measure valve stem leakage during actual testing. Prior to the start of testing the enclosure is evacuated to one-fourth psia by the system vacuum pump. The gas environment in the chamber is monitored by the mass spectrometer on a periodic basis at predetermined times. Extremely small quantities of fuel gas leakage can be detected by the mass spectrometer and its concentration measured. A large leak could be measured by the increase in pressure in the chamber.

4.8.3 Valve Mounting and Changeout

Within the test cell enclosure, the hot gas piping has an open section five foot in length to accommodate the test valve; 22inch standard API flanges are on either face of the hot gas pipe. Each test valve will be mounted with appropriate spool adaptor section to mate with the hot gas pipes in the test cell. A monorail with a small hoist is provided over the test cell enclosure to allow the removal and replacement of the test valves.

Shut-off valves are provided in the hot fuel gas line upstream and downstream of the test cell. These are Type III, eight-inch, 2000F, solids valves as being developed by METC for high temperature lockedhopper applications. For normal valve changeout, these valves are closed and the high pressure hot gas is purged from the valve with nitrogen. With the use of these shut-off valves, it is not necessary to depressurize the system or to cool it down in order to change valves. Hence, the system can return to full test operation immediately after the new valve is secured into place and the instrumentation is connected. 
4.8.4 Valve Actuation

Valve actuators may be electrical or hydraulic and are contained in the test cell enclosure. All valve instrumentation is similarly mounted.

4.9 Gyclone

\subsubsection{Performance}

Particulate in the hot gas stream approaching the test valve is predominantly in the one lo len micions size tanye and is 0.6 pes cent by weight of the gas stream. The particle load has been calculated to be typical of that leaving a gasifier in which two cyclone stages are used for clean-up. The cut point of the downstream cyclone was 25 microns. (Cut point defines the particle size at which the cyclone's efficiency is 50 per cent.)

For many of the valve tests with coal ash at the elevated temperatures, considerable agglomeration of the particles may be expected as they pass through the turbulent and high velocity zones in the valve itself. Consequently, the average particle size should be somewhat greater downstream of the valve than upstream of the valve.

The cyolone ueod in the valve tcot facility has a cut point of threc miorone and thereforc ohould bc capable of collecting pcrhapa 70 per cent of the incoming particles. High collection efficiency is obtained by accepting higher pressure drops than normal and by allowing the two per cent bleed flow from the bottom to remove the fines before they are reentrained in the gas stream.

4. 9.2

Construction

As shown in the sketch of the cyclone in section 3, the cyclone is constructed of a mild steel outer shell with both an insulating refractory lining and hard face refractory li.ning. This lining is periodically renewed to compensate for wear. 


\subsubsection{Particulate Disposition}

The particulate removed by the cyclone is transported to the baghouse by the two per cent bleed flow from the cyclone. Finned pipe is employed for the transport line to cool the gas and particulate during transport. A valve at the cool end of line near the baghouse controls the flow rate.

\subsection{Heat Exchanger Subsystem}

\subsubsection{Media}

The heat exchanger subsystem contains 391,000 pounds of heat transfer media. These media are one-quarter inch diameter spheres made from aluminum oxide. They are available from several vendors; Alcoa specifies theirs as T-162 Tabular Alumina Spheres. This spherical alumina is employed by the chemical processing industry for a wide variety of uses. It is ideal for use in the dirty gas heat exchanger because it will not react with coal ash at $1750 F$. Further it has considerable resistance to abrasion eyen at the higher temperatures.

The distribution of the media, by weight, in the system is listed below:

$\begin{array}{lc}\text { Heat Recovery Section } & 26,000 \text { pounds } \\ \text { Media Heating Section } & 211 \\ \text { Gas Heating Section } & 364,400 \\ (182,200 \times 2) & 500 \\ \text { Lift pipe and media } & \\ \text { disengagement chamber } & 391,111 \text { ivinds }\end{array}$

4.10.2 Heat Recovery Section

The heat recovery section is substantially as described in section 3.10 .1 and illustrated in Figure 3-21.

4.10.3 Media Heatiny Seiliún

The media heating section is substantially as described in Section 3.10 .2 and illustrated in Figure 3-22. 
The gas heating section is substantially as described in section 3.10 .3 , and illustrated in Figure 3-23.

4.10.5 Media Lift Assembly

The Iluw rale of the media through the heat recovery section, thc media heating section, and the qas heating section is controlled by Llie rate at which media is withdrawn from the bage of the gas hcating section. The media is withdrawn using a fuel gas transport to move it to the media lift where it is lifted 85 feet to the media disengagement chamber atop the heat recovery section. The media lift pipe is three inches in internal diameter.

As shown in Eigure 4-1, the lift compressor draws fuel gas from the test loop upstream of the main compressor and supplies the pressurized fuel gas to lift the media. The flow rate for the lift gas is 2.3 pounds per second and the pressure drop across the lift is $19 \mathrm{psi}$. Compressor power is $14 \mathrm{kw}$. As shown in Figure 4-2, the lift compressor is located on the east side of the pad, adjacent to one of the vessels of the gas.heating section.

\subsubsection{Air Compressor}

As discussed earlier, the media is heated from $1730 \mathrm{~F}$ to $1770 \mathrm{~F}$ passIny throuyh the medid liedliny stulivil. Tlis heat is supplied by hot products of combustion from burning propane in preheated air; the temperature of the hot gas being 2500F. Because the media heating section must be operated at the test loop pressure downstream of the test.valve, the air for the burner must be pressurized to 250 psia before it can be heated and used in the media heater.

As illustrated in Figure 4-1, compression will occur in two stages with an intercooler interposed between stages. The tirst stage will be an electrically driven compressor and the second stage will be driven by an exhaust turbine operating with spent products of combuotion at $337 \mathrm{pcia}$ and $330 \mathrm{~F}$. Power for the electrical compressor is $109 \mathrm{kw}$. 
PAGE NO

4.10.7 Air Regenerator

The air regenerator is used to capture the heat from the exhaust of the media heating section (1750F) and transfer most of it into the incoming air to the propane burner, heating it to 1600F. A conventional extended surface heat exchanger is employed; it is located on the south side of the pad adjacent to the air compressor package.

4.10.8 Propane Burner and Auxiliaries

The propane burner is used to heat the air from $1600 \mathrm{~F}$ to $2500 \mathrm{~F}$ for media heating. It is also used to heat up the media from ambient to $1770 \mathrm{~F}$ for a cold start. Burners are not currently available that will operate at 250 psia with $1600 \mathrm{~F}$ preheat. However the development of such a burner is not difficult and can easily be accomplished by a specialty burner manufacturer. Standard burner safeguards are included with the burner:

4.10.9. Structure

All of the vessels and piping are held in a structural steel framework anchored in the $50^{\prime} \times 50^{\prime} \times 5^{\prime}$ concrete pad. The structure will contain walkways with OSHA safety guards for access to all major components.

4.10.10 Safety Items

Where appropriate, water spray systems, blast guards, etc., will be provided.

4.11 Particle Removal Sub-System

All particles are removed from the system by the baghouse. The particles are transported to the baghouse by the bleed air from the cyclone and the lift gas from the media lift. Both gas streams and particles are cooled, hence a conventional baghouse may be employed. It is, however, contained in a pressure shell for operation at the system pressure of 250 psia. The baghouse is located on the west side of the pad. 
4.11 (continued)

A locked hopper is used to remove the particles from the hopper of the baghouse. Used particulate is transported from the site by closed trailer trucks normally used for bulk solids transport. Spent particulate will be either used for construction fill or buried in a landfill.

\subsection{Main Compressor}

The main compressor is an electrically driven reciprocating compressor requiring $882 \mathrm{kw}$ of power when the test loop is operating at the one-half flow condition. To save power the compressor is divided into two stages with intercooling. An evaporative spray tower is used to provide cool water to the intercooler.

\subsection{Control Subsystem}

4.13.1 System Start-Up Sequence - Cold Start

When starting from a cold start the procedure is to first heat half of the media to operating temperature while allowing the test loop to remain filled with air at atmospheric pressure. To accomplish this the air compressor is activated to blow air through the air regenerator, through the propane burner, and finally through the media heating section. The burner is ignited and the exit gas temperature is adjusted to 2000F. The lift compressor is started and media circulation is begun at the proper rate to achieve a media exit temperature of $1750 \mathrm{~F}$. This procedure is maintained for 48 hours, at which time one of the vessels of the gas heating section is filled with 1750F media.

Next the two valves between the air regenerator and the air compressor are closed, isolating the test loop from the atmosphere. The vacuum pump is started and the test loop is evacuated to onequarter psia air pressure.

Gases are individually charged into the test loop until the desired mixture is obtained. Precalculated amounts of each gas are charged into the system but the overall composition is monitored by the gas composition instrument (mass spectrometer) and adjustments are made as required to achieve the proper mixture. 


\subsection{1 (continued)}

The main compressor and lift compressor are started to establish the flow of gas and media in the circuit. Several hours operation will be required to preheat the ceramic liner of the hot gas piping.

As soon as fuel gas flow and media flow are established, the air compressor is brought up to speed until the exit air pressure matches the pressure in the media heating chamber. The two valves between the air compressor and the air regenerator are opened to establish air flow through the media heating chamber. The exit valve is controlled to maintain the pressure level in the media heating chamber within a few inches of water of that in the heat recovery section. Sensors measure the differential pressure across the seal leg of the heat recovery section and command the exhaust air valve to maintain this at zero.

After pressure balance is maintained, the propane burner is ignited and the media heating function is established.

4.13.2 System Start-Up - Valve Change-out

System start-up after valve change-out is simplified because the media is hot and the system is charged with fuel gas at the appropriate pressure. It is only necessary to establish the hot air flow through the media heating section after starting the main. compressor and lift compressor.

\subsubsection{System Control During Valve Testing}

Steady state conditions are established with the test valve wide open at a system pressure below that ultimately desired when the valve will be cycled to a partially closed position. The hot gas flow rate through the loop is determined by adjusting a flow control valve upstream of the compressor inlet. The temperature of the hot fuel gas is adjusted by the propane flow rate to the propane burner, which in turn heats the media. The media then heats the hot gas. The media flow rate is adjusted to match the heat transfer rates required for the selected gas flow rate. 
PAGE NO. $4-20$

4.13.3 (continued)

Before proceeding with a discussion of the dynamics of the system, it is worthwhile to review the volumetric capacity of the various components of the system and the weights of gas they contain.

\begin{tabular}{lcc} 
Cnmonnent. & $\begin{array}{c}\text { volumetric Capac1ty } \\
\left(f t^{3}\right)\end{array}$ & $\begin{array}{c}\text { Welght of Gas } \\
\text { (pounds) }\end{array}$ \\
\cline { 1 - 2 } Heat Recovery Section & 158 & 32 \\
Gas Heating Vessel & 541 & 108 \\
Piping & 185 & 37
\end{tabular}

For a valve cycling with a 15-second period, when the valve is closing the main compressor will quickly evacuate the volume of the test loop downstream of the test valve and charge the gas into the vessel of the gas heating section, slowly increasing its pressure. All of the flow resistances throughout the loop would cause these fluctuations to be damped and to increase the phase shift. A computer model of the dynamic system is needed to obtain the final results.

During cycling of the test valve, the pressure in the base of the heat recovery section is constantly changing. As mentioned before, the pressure differential across the downcomer leg between: the heat recovery section and the media heating section is monitured by a control loop which adjusts the pressure in the medla heating section to match it by controlling the air supply valves. Hence, the pressure level in the media heating chamber will tend to follow the pressure in the test loop.

When the pressure in the media heating chamber fluctuates due to valve opening and closing, these pressure pulses will be transmitted to the vessel of the gas heating section which is currently being filled with hot media. To preclude loss of fuel gas from the test loop, the test valve is held at its one-half flow position during changoover of the gas heating vessels (every two hours). The vessel which is about to receive hot media is vented to the compressor inlet line and hence will seek the lowest system pressure. The . $:$ vent line is closed after switchover. 
PAGE NO

4.13.3 (continued)

Subsequently, pressure excursions above this value will force some products of combustion from the media heating vessel into the gas heating vessel but little gas mixing is expected to occur because of the impediment to free gas flow caused by the media in the vessel.

Particulate flow into the test loop can be initiated by actuating the feeder. Particulate removal occurs automatically by the functions of the cyclone, media lift, and baghouse.

4.13.4 System Control During Shut-Down

To shut down the system for a short duration, the air valves between the air compressor and the air regenerator are closed and the main compressor and lift compressor are stopped. For a long duration shut-down or for maintenance work on the system, the test loop must be depressurized and purged of fuel gas. The incinerator is activated and the vent valve from the test loop to the incinerator is opened, flaring the fuel gas from the system. When atmospheric pressure is reached, the vacuum pump is started and the test loop is pumped back down to one-fourth psi. Fresh air is admitted to the system. The main compressor may be used to pump fresh air through the media beds (exhausting to the atmosphere) to cool them.

\subsubsection{Control Equipment}

The sequences of control action necessary to successfully operate the system may be separated into three categories:

1. Start-up and shut-down sequences. This sequence of actions would include the partial shut-down of the system required for valve change out and emergency shut-down, if necessary, in addition to shut-down for the yearly routine maintenance called for.

2. Test valve cycling. This is the valve cycling to half-flow ieyuired every fifteen seconds as a primary part of the valve testing. 
PAGE NO

$4-22$

\subsection{5 (continued)}

3. Control actions necessary to maintain system operating parameters within specifications. Sicne the flow medium is a potentially explosive mixture of gases at relatively nominal temperatures and pressures, all control actions w1ll be performed remotely by the operator(s) in lie control Room.

To provide efficient continuous monitoring and control of the test loop, operator commands will be centralized through a desk top computer with a CRT display. Such computers, with all the requisite capabilities, are manufactured by Hewlett-Packard, Tektronix, and others. For illustration, the capabilities of the Hewlett-Packard 9800-Series 45 computer system are discussed here.

As mentioned, this is a desk top unit with a CRT display. A schematic of the flow loop would be displayed on the CRT screen. Pressure, temperature, and other appropriate data at various points in the flow loop would be displayed at corresponding points on the screen. The computer would be programmed such that the operator will be warned of conditions requiring corrective action by the flashing of the display at the point on the loop where the condition of concern is occurring. The operator may then command corrective action directly through the computer keyboard. Thus the computer would provide both monitoring and control of flow loop performanee.

Further, sufficient storage capability would be available either in the integrated memory of the system, or through peripheral hard disc packs, to acquire and store data. This particular system can read at better than $200,000 \mathrm{~Hz}$ per second on 32 channels. Thus, if as envisioned data is acquired on about 60 channels, the complete set of flow loop data can be easily scanned at one-half second intervals or more frequently if necessary. The comptuer system would be allied with a Hewlett Packard 6942 microprogrammer with the approprinte rarda to enntrol the various valve aotuatore as required.

The computer system can be programmed to automatically provide the sequence of commands necessary to cycle the test valve or otherwise control the system. It can shut the system down should a dangerous condition develop. The eyetem can be manually controlled at the discretion of the operator at any time. 
PAGE NO

$4-23$

\subsection{5 (continued)}

In addition to the above, system gauges will be provided to (redundantly) monitor system condition at various points. Manual controllers for the various valve actuators (as distinct from the automatic controls through the computer) will also be provided so that the operator may control the system in case of a computer malfunction, or for other reasons.

The valves controlling the flow loop, including the test valve itself, would be operated by remotely operable actuators. The sequence of valve positions required during start-up and shut-down would be achieved manually by the operator's action. The test valve cycling required will be automatically performed by preprogramed computer commands. The control of the particulate feed rate motor, the burner heat input control, and gas feed would also be automatically controlled by the computer system.

\subsection{Instrumentation Subsystem}

\subsubsection{General}

The instrumentation subsystem is designed to measure parameters on the test facility and on the valve to be tested. Outputs from both transducers are directed to the desk-top calculator for use in control of the facility and to provide information to the operators for operating the facility. Back-up instruments are also provided in the event of computer malfunction. Following the METC specification, continuous monitoring of the test parameters for the valve are provided. These will be recorded vil strip charts operated continuously during the test period.

4.14.2 Process and Instrumentation Diagram

Figure 4-1 provides the process and instrumentation daigram for the system.

All temperatures will be measured with Type $K$ chromel alumel thermocouples; manual readout will be with two Fluke digital thermometers, Model No. 2160A. Leeds \& Northrup Model 820816 thermocouple selector switches will be used. 
PAGE NO

$4-24$

4.14.2 (continued)

Pressures will be measured with Validyne equipment. Pressure transducers will be Model DP-15 with 500 psi diaphragm; signal conditions will be with Model CD-19-529 carrier demodulators with high sensitivity shunt capability. A Fluke multimeter Model 8600 A will be used for readout.

Strip chart recorders for valve test data will be Albeon Model 345 recorders with input from $\mathrm{lmv}$ to $50 \mathrm{v}$ and chart speed from one centimeter per hour to 30 centimeters per minute.

The gas composition instrument will be a UTI mass spectrometer, Model Q-30C with a control and data system.

4.14.3 Measurement Accuracies

The measurement accuracies specified on Page 18 of METC/CR-79/10 will be met by the instrumentation previously discussed. 


\section{SECTION 5 - ORGANIZATION AND FACILITIES}

\section{$5.1 \quad$ Norco Test Facility}

The hot dirty gas valve test facility will be located at the Norco, California testing site of Wyle Laboratories. Norco is located in the Los Angeles basin not far from Riverside, California. Figure 5-1 is an aerial view of the Norco facility showing the administrative buildings, shops, and various testing sites. Figure 5-2 is a map of the Norco Facility. This facility is over 400 acres, completely fenced, and has a 24-hour guard service, seven days a week.

The Norco facility is the largest of the six Wyle facilities and operates as the main offices for Western Operations Scientific Services and systems Group. The facility is divided into four main operating departments, which are as follows:

- Nuclear Engineering Services Department

- Dynamic Test \& Engineering Department

- Fluid Systems Department

- Electronics/Environmental Test Department

All Wyle test facilities maintain a Quality Assurance program which is in strict compliance with both industry and government standards.

5.2

\section{Test Site Location}

Figure 5-3 is a drawing showing the proposed location of the hot dirty gas valve facility in the Norco test site. The facility would be located near the center of the site and adjacent to the EPRI nuclear safety valve test area.

To make use of existing facilities, the hot gas valve program will share the control room with the EPRI program. Figure 5-3 shows the location of the existing control room in proximity to the $50^{\prime} \times 50$ ! test pad. 


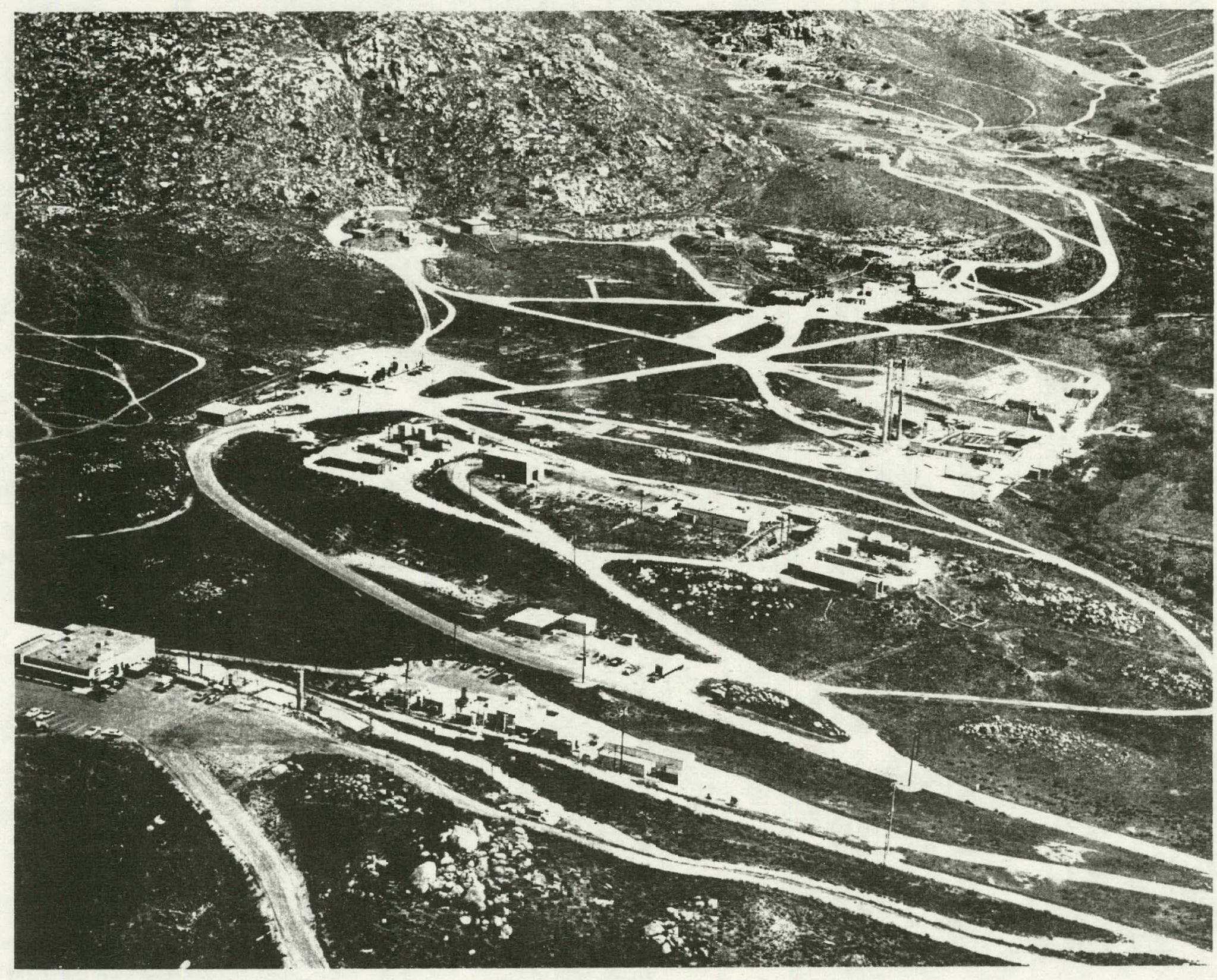

FIGURE 5-

WYLE INCF.CO TEST FACILITY 


\section{WME LABORATORIS}

\section{MAP OF NORCO FACILITIES}

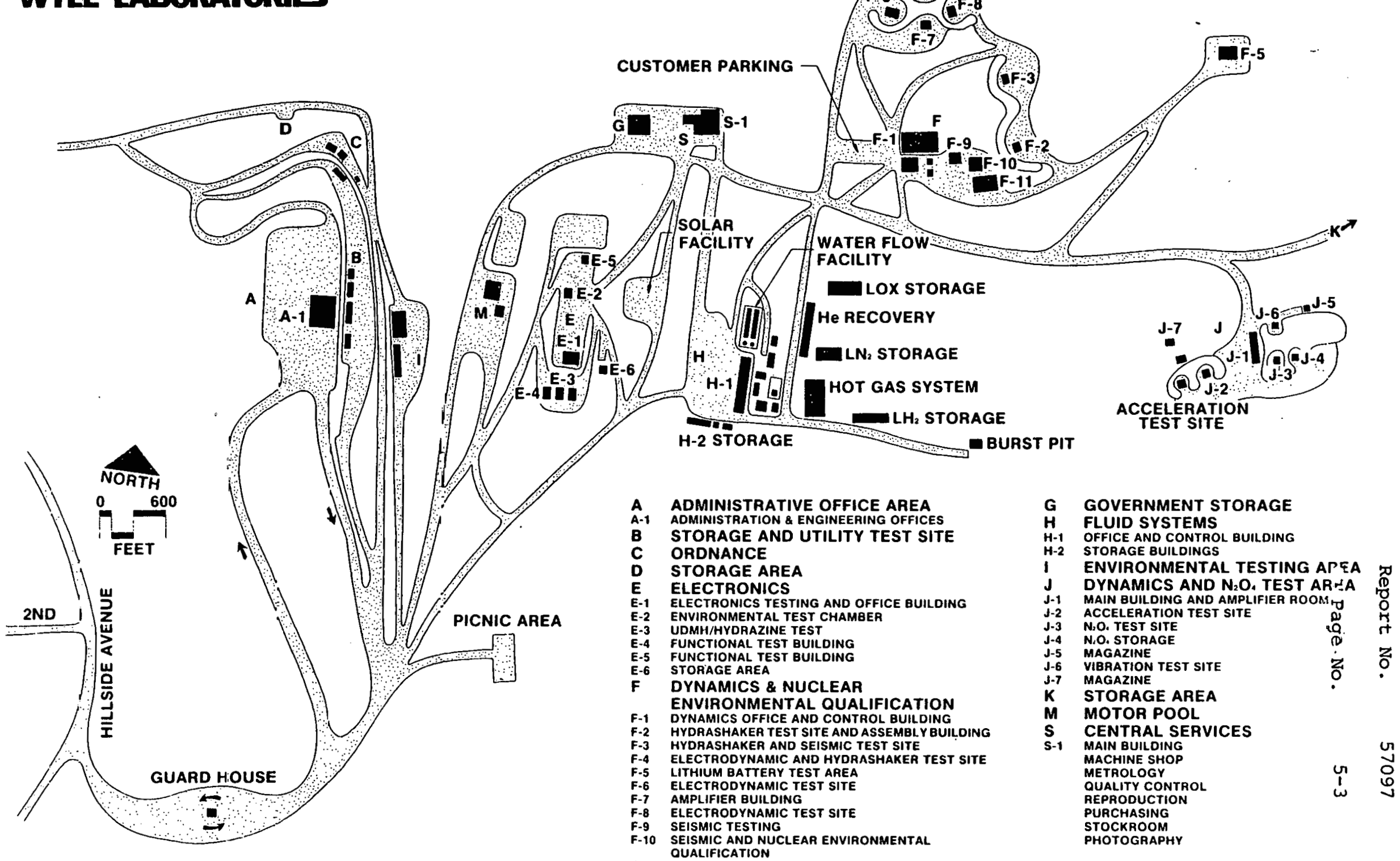




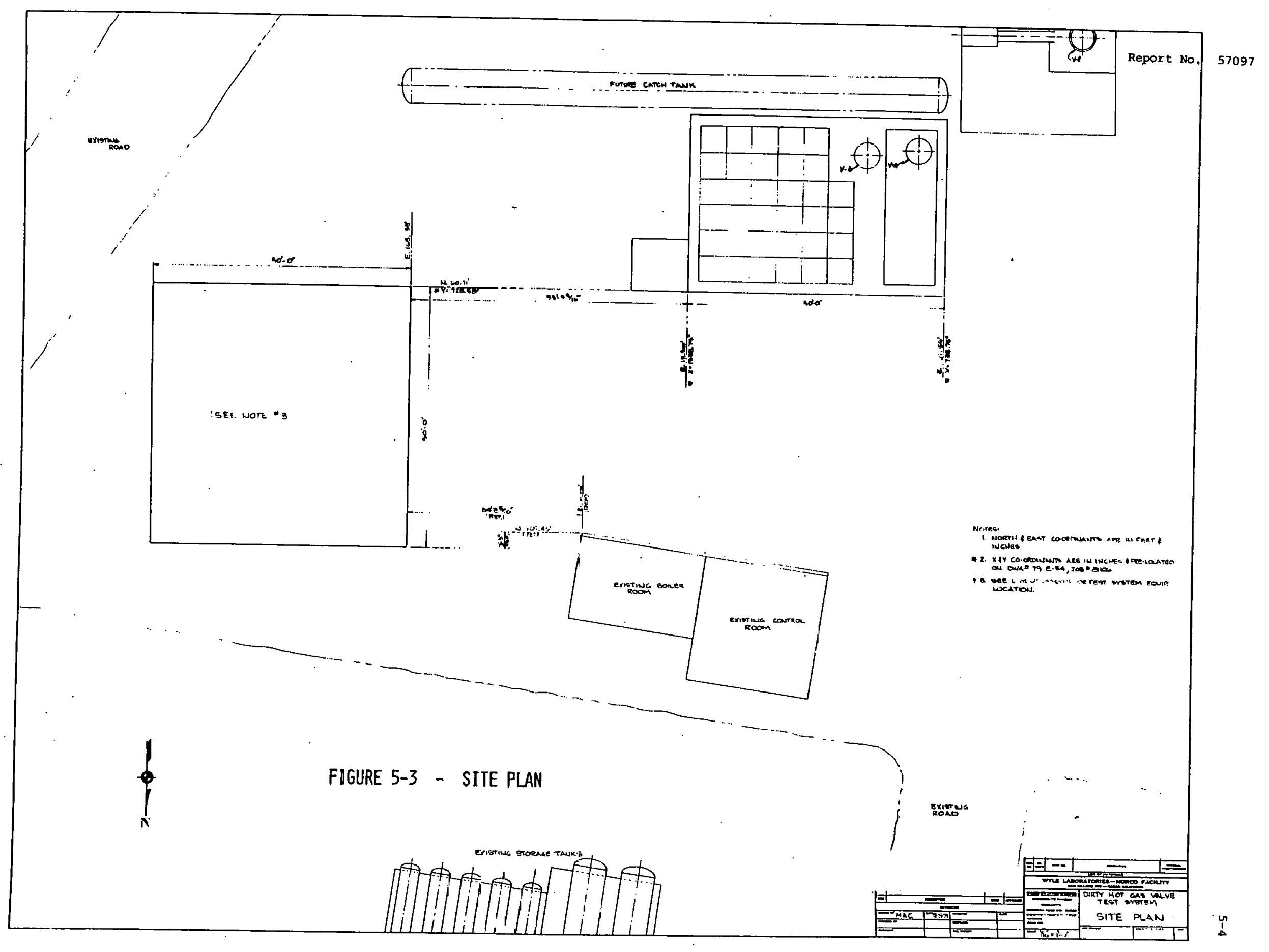




\section{$5.3 \quad$ Organization}

\subsubsection{Introduction}

Wyle Laboratories, founded in 1949, was the first company exclusively devoted to providing professional, independent laboratory testing services to the aircarft industry. The need for this service was identified with the development of high performance modern aircraft and the realization that test flights as a primary means of product qualification were too complex an undertaking and too costly to provide individual control and qualification of component and systems performance criteria. It was also evident to hundreds of manufacturers of these components and subsystems that available centralized test facilities to qualify their products were economically desirable.

By the mid-1950's the company, with test facilities in El Segundo and Norco, California, was nationally recognized for performance of mechanical, hydraulic, fuel, pneumatic, electro-mechanical, and electronic testing of any component and/or system on both military and commercial aircraft.

Wyle Laboratories today is a mid-sized composite California corporation with sales over 200 million dollars a year and its stock traded on the New York Stock Exchange. Four principal groups form the corporation covering areas of manufacturing, transportation, electronics distribution, and scientific services systems.

\subsubsection{Scientific Services and Systems Group}

The Scientific Services and Systems Group remains the nation's largest independent research, engineering, and test organization. Since the 1950 's the 35 Group has applied our expertise as a major contractor in many fields, such as Nuclear, Marine Technology, Solar, Space Shuttle, Petroleum and General Aerospace. The 35 Group currently operates out of six facilities, which are:

- Colorado Springs, Colorado

- El Segundo, California *

- Hanptun, Visginia

- Huntsville, Alabama

- Norco, California $\pm *$

- Washington, D. C.

* Also Corporate Offices

** Facility proposed to perform this program 
5.3 (continued)

Although the 35 Group is functionally divided into two operating divisions, personnel and facility resources are commonly shared throughout the entire Group. This management concept allows for maximum flexibility in planning and staffing individual programs as conditions require.

The rcoponoibility for the proposed program will be assigned to the Norco facility of Western Operations. The cognizant department for the program will be the Fluid Systems Department with support as required from other departments, wuoh as the Nuolear Engineering Services Department. 
The Wyle Norco test site has the following basic facilities to support the. HDGV Test Facility:

ITEM

High Pressure Flow system

Steam Source for Heating the Primary Vessels

\section{Raw Water}

Storage Water

Demineralized Water

Deaerated Water

Nitrogen "Supply

\section{DESCRIPTION}

This facility offers a 300 cubic foot, 5800 psi MWP primary vessel rated for $650 \mathrm{~F}$. The system also has a 600 cubic foot, 6000 psi gas storage vessel to provide rapid system pressurization.

One each, 6900 pounds per hour, 3100 psi, $650 F$, vapower water tube boiler, to be used as the primary heat source.

As a second source system, the Norco facility currently has operational: one each 5500 pounds per hour, 1500 psi, 600F, $150 \mathrm{hp}$, Texsteam vertical tube boiler, to be used as a primary heat source.

The raw water is city-supplied at $120 \mathrm{psi}$ and. is available for recirculation as cooling water. Water is available in the test area for the system.

20,000 gallon storage tanks at the steam site.

A three-tank Cation, Anion demineralizer cubicle of $20 \mathrm{gpm}$ and expandable to $50 \mathrm{gpm}$.

The Norco facility has a 130-gallon, open surface deaerater operating at $15 \mathrm{gpm}$ and 190F. Further $\mathrm{O}_{2}$ scrubbing is accomplished by use of a hydrazine compound to reduce the $\mathrm{O}_{2}$ content to less than $20 \mathrm{ppb}$. System is expandable to $50 \mathrm{gpm}$.

One each, $6000 \mathrm{psi}, 600$ cubic foot supply system is currently available for gas pressurization. 


\section{ITEM}

Shop Air

Power

Machine Shop

Photography

Printing

Calibration

Valve Repair Area

Eccured 'l'est Area and Access Control
DESCRIPTION

120 psi shop air is available at the steam site.

12,000 volt, 400 amp per leg primary drop. Reduced to $5160 \mathrm{v}$ at a ma1n transformer station where reduction to $440 \mathrm{v}, 408 \mathrm{v}$, or $220 \mathrm{v}$ is available.

An 8000 square foot machine shop with lathes, vertical mill, grinding and milling machines, and arc and acetylene welding. Also available are electrical installation and repair facilities and portable welding services.

Complete developing and enlargement capabilities for $35 \mathrm{~mm}$ to $4 \times 5 \mathrm{film}$. High speed movie cameras may be available with development off-site.

Both offset and xerography printing are available.

The calibration laboratory has secondary standards for the calibration of voltage, resistance, pressure, acceleration, frequency, and length, all traceable to N.B.S. Available is a complete instrument repair facility.

Contained within the existing liquids test. area are suitable spaces for overhaul and repair of valves.

Tlie Lest areas are completely fenced with formalized access control procedures and a 24-hour security service. Access control is also available for the individual test sites. 
5.4 (continued)

ITEM

Al1-Weather Access Roads

Surface Draining Rights

Computer System
DESCRIPTION

18-foot wide, all-weather, heavy-duty roads are available throughout the test site and are capable of carrying most loads.

The Norco facility is not connected to any city sewage system, thus eliminating any water draining problems.

Varian V76 computer, 16-bit word length, and with $32 \mathrm{~K}$ words of memory. The system is designed for handling 256 channels of analog signals with an overall data throughput rate of 270,000 measurements per second total. 
Figure 6-1 presents the overall construction schedule for the hot dirty gas valve facility at Norco. As seen from the figure, testing can begin approximately two years from go-ahead. 


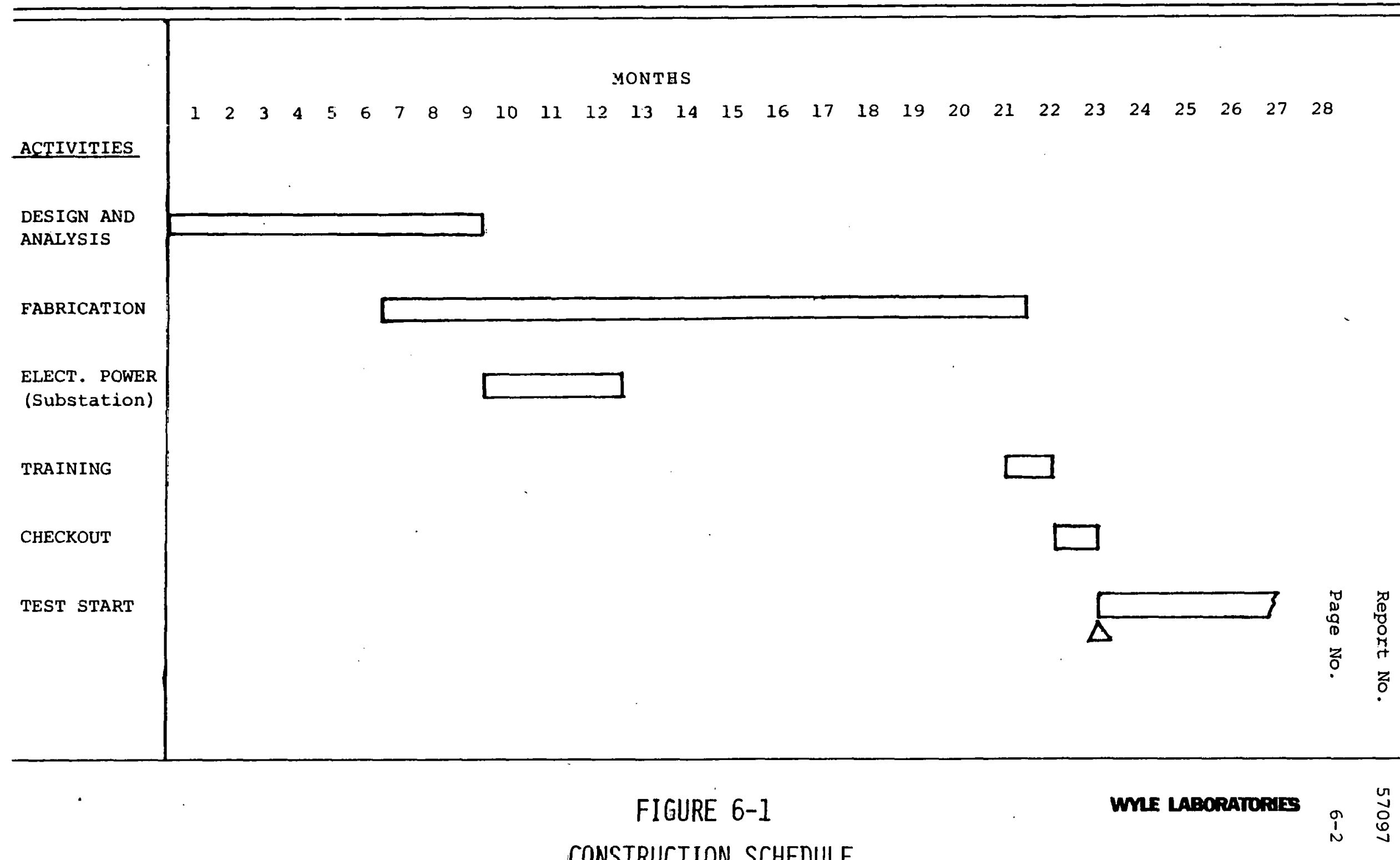

CONSTRUCTION SCHEDULE 
Table 7-1 presents a summary of the estimated costs for the hot dirty gas valve test facility described earlier in section 4. Table 7-2 provides a breakdown of those costs to the component level.

Table 7-3 presents the estimated costs for operating the test facility for 8000 hours per year. 
HDGV CLOSED LOOP TEST SYSTEM

\section{MAJOR PROGRAM COST SUMMARY}
A.
SYSTEM FABRICATION $\varepsilon$ INSTALLATION
$\$ 9,825,000$
B.
FRUGGAM MANAGEMENT AND CONTROL
875,000
C.
SYSTEM OPERATION - ONE YEAR
$2,295,000$
D.
FIRST YEAR SYSTEM CHANGE-OUT
766.000
ESTIMATED TOTAL PROGRAM COST:
$\$ 13,761,000$
COST ESTIMATES PRESENTED DO NOT INCLUDE CONSIDERATION FOR ROYALTIES.
DCTAILLD COST BREAKDOWN FOR EAGH DF THE ABOVE MAJOR ITEMS IS SHOWN ON TABLES 7-1 THROUGH 7-5. 
IABLE 7-1

SYSTEM FABRICATION \& INST:- $-A T I O N$

INDIVIDUAL MAJOR SYSTEN CENPENENTS

1. DESIGN AND ANALYSIS

$\$ 800,000$

2 .

PAD AND STRUCTURE

630,000

3.

PARTICLE RECEIVING ANC ミテニミ:ミミ

70,000

4.

FLOW LOOP

$2,800,000$

5 .

HEAT EXCHANGER

$4,600,000$

6 .

CONTROL AND INSTRUMENT $\mathcal{A}^{-}::$

420,000

7.

FACILITY IMPROVEMENTS

250,000

8.

SYSTEM CHECKOUT

255.000

$\$ 9.825 .000$ 
TABLE 7-2

SYSTEM COST BREAKDOWN

1. DESIGN AND ANALYSIS

$\$ 800,000$

2 .

PAD AND STRUCTURE

REACTION MASS AND PAD $\$ 220,000$

SUPPORT STRUCTURE $\quad 375,000$

IIR C.RANE

35,000

3. PARTIELE RECEIVING NND ETORAGE

70.000

4. FLOW LOOP

4. 1 HOT PIPING

22-INCH PIPE

INTERIOR INSULATION

EXTERIOR INSULATION

$\$ 230,000$

140,000

30,000

FLANGES, BOLTS, ETC.

$5.8,000$

13,000

$X$-RAY

CRANE RENTAL

80,000

INSTALLATION

359,000

4.2 MAIN COMPRESSOR AND AUXILIARY COMPRESSOR 210,000 COOL DOWN PIPING \$ 8,000 COMPRESSOR BLOCK VALVES 165,000 COMPRESSOR

12,000 COOLING TOWER \& PUMP WATER TANK

9,000 16,000

4.3 PART I CULATE FEEDER FEEDER \& WQGKED HOPPER

50,000

4:.4 CYCLONE

170,000

4.5 TEST CELL MONORAIL PRESSURE VESSEL $\varepsilon$ INSULATION

$\$ 15,000$ 120,000 105,000

4.6 HOT VALVES

TYPE III - $1800^{\circ} \mathrm{F}(2 \mathrm{EA})$

530,000

4.7 VACUUM \& INCINERATION EQUIPMENT

INCINERATOR

FLAME ARRESTOR

PIPES $\&$ VALVES

VACUUM PUMP

MAIN INCINERATOR
$\$ 15,000$

5,000

17,000

3,000

40,000 
TABLE 7-2

SYSTEM COST BREAKDOWN (CONTINUED)

4. FLOW LOOP (CONTINUED)

4.8 GAS INLET VALVES \& REGULATORS

$\$ \quad 35,000$

4.9 PARTI CLE REMOVAL

BAG HOUSES

$\$ 16,000$

575,000

SPARE BAGS

5,000

PRESSURE VESSELS

554,000

4.10 MISCELLANEOUS

120,000

TOTAL, ITEM 4.:

$\$ 2,800,000$

5 .

HEAT EXCHANGER

$\$$

190,000

5.1 HEAT RECOVERY SECTION VESSEL AND

26,000 INSULATION

5.2 MEDIA DISENGAGEMENT CHAMBER

260,000

5.3 MEDIA HEATING SYSTEM

780,000

5.4 MEDIA

$117 ; 000$

5.6 AIR RECUPERATOR

65,000

5.7 BURNER AND AUXILIARY

585,000

5.8 AIR COMPRESSOR

117,000

5.9 LIFT COMPRESSOR

20,000

5.10 PIPING

14-INCH PIPING

8-INCH PIPING

10-INCH PIPING

FLANGES, BOLTS \&

GASKETS

TORQUL WREPUCHES

$X-R A Y$

6-INCH PIPE

EQUIPMENT RENTAL

$\$ 15,000$

255,000

25,000

55,000

89,000

27,000

9,000

22,000

13,000

5. 11 EXPANSION JOINTS

180,000

5.12 TYPE III HOT VALVES - $1800^{\circ} \mathrm{F}(6$ EA)

$1,575,000$

5.13 INSTALLATION

400,000 
TABLE $7-2$

SYSTEM COST BREAKDOWN (CONTINUED)

5.14 CRANE

5.15 MISCELLANEOUS

TOTAL, ITEM 5.:

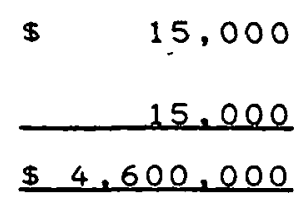

$\$ 138,000$

130,000

30,000

$\$ 5,500$

10,000

12,000 900

1,600

6.4 TEMPERATURE MEASUREMENTS

THERMOCOUPLES

PLUGS \&. WIRE

DIGITAL METER

SW IT CHES

$\$ 4,000$

4.500

1.500

2.500

6.5 RECORDERS

10,500

6.6 INSTALLATION

29.000

TOTAL, ITEM 6.:

12,500

$\$ 420,000$

7.0 FACILITY IMPROVEMENTS

7.1 ELECTRICAL POWER INTO COMPRESSORS

$\$ \quad 148,000$

7.2 VALVE SERVICE $\&$ STORAGE AREA

60,000

7.3 MODIFICATION OF EXISTING FACILITIES

28,000

7.4 DELUGE

7.5 BLAST SHIELD

9,000

5.000

TOTAL, ITEM 7.: 
TABLE 7-2

SYSTEM COST BREAKDOWN (CONTINUED)

$\begin{array}{ll}8.0 & \text { SYSTEM CHECKOUT } \\ 8.1 & \text { MANUALS } \\ 8.2 & \text { TRAINING } \\ 8.3 & \text { PERMITS } \\ 8.4 & \text { CHECKOUT }\end{array}$

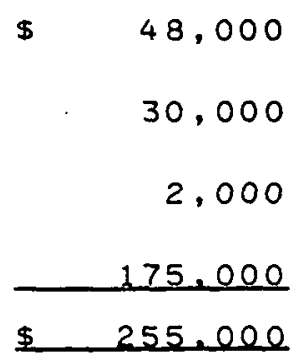

TOTAL, ITEMS 1 THROUGH 8 :

$\$ 9.825,000$ 
Report No. $\quad 57097$

Page No. $\quad 7-8$

IABLE $\quad 7-3$

PROGRAM MANAGEMENT $\varepsilon$ CONTROL

1. SUPERVISION AND COORDINATION OF

ACTIVITIES DURING COURSE OF PROGRAM \$ 875,000

(Including report preparation)

$\$ \quad 875.000$ 


\section{TABLE 7-4}

SYSTEM OPERATION COST SUMMARY (1 YEAR)
1 .
SYSTEM OPERATION
$\$ \quad 875,600$
2 .
SYSTEM MAINTENANCE
(EXCEPT FOR MAJOR SHUTDOWN)
168,900
3.
SYSTEM CAL IBRATION
24,000
4 .
MAINTENANCE - FULL SYSTEM SHUTDOWN
( 31 DAYS)
5. ELECTRICAL POWER
$1,061,000$
6. PROPANE
45,500
7.
SYSTEM FUEL MAKE-UP
14,000
8.
FLY-ASH DELIVERY
32,500
9. FLY-ASH DISPOSAL
32.500
$\$ 2,295,000$
COST PER HOUR
$\$ 287.00$ 
Page No.

TABLE 7-5

FIRST YEAR SYSTEM CHANGE OUT COST SUMMARY

1.

CHANGE-OUT OF PIPING CIRCUIT

NEW 22-INCH PIPE

$\$ \quad 766,000$

NEW INSULATION

REWORK OLD PIPE $\varepsilon$ REINSULATE

$\$ 780,000$

